\title{
Revision of the Bee Genus Chlerogella (Hymenoptera, Halictidae), Part II: South American Species and Generic Diagnosis
}

\author{
Michael S. Engel \\ Division of Entomology, Natural History Museum, and Department of Ecology \& Evolutionary Biology, Uni- \\ versity of Kansas, Lawrence, Kansas, USA \\ urn:lsid:zoobank.org:author:3714A7FF-E19E-495A-AAF9-98D2F597B757 \\ Corresponding author: Michael S. Engel (msengel@ku.edu)
}

Academic editor: Michael Ohl| Received 24 February 2010 | Accepted 19 April 2010 | Published 21 May 2010

urn:lsid:zoobank.org:pub:975251CE-C173-4D80-84B9-C14B870330F9

Citation: Engel MS (2010) Revision of the Bee Genus Chlerogella (Hymenoptera, Halictidae), Part II: South American Species and Generic Diagnosis. ZooKeys 47: 1-100. doi: 10.3897/zookeys.47.416

\begin{abstract}
The South American species of the rare bee genus Chlerogella Michener (Halictinae: Augochlorini) are revised, completing the study of the genus. Chlerogella diversity is significantly expanded beyond the five previously described South American species of Chlerogella azurea (Enderlein) comb. n., C. nasus (Enderlein), C. mourella Engel, C. octogesima (Brooks and Engel) comb. n., and C. buyssoni (Vachal). Twenty-two new species are described $-C$. agaylei sp. n., C. arhyncha sp. n., C. borysthenis sp. n., C. breviceps sp. n., C. cochabambensis sp. n., C. cooperella sp. n., C. cyranoi sp. n., C. dolichorhina sp. n., C. elysia sp. n., C. eumorpha sp. n., C. euprepia sp. n., C. hauseri sp. n., C. hypermeces sp. n., C. materdonnae sp. n., $C$. oresbios sp. n., C. picketti sp. n., C. rostrata sp. n., C. silvula sp. n., C. terpsichore sp. n., C. tychoi sp. n., C. vachali sp. n. C. xuthopleura sp. n. - and the distribution of the genus is expanded beyond Perú and Ecuador to include Bolivia, Colombia, and Venezuela. The female of C. azurea is described for the first time while the placement of Halictus buyssoni Vachal in Chlerogella is considered tentative, following the usage of previous authors, as the holotype and sole specimen is untraceable. The genus is newly diagnosed based on a greater understanding of variation in malar length across the species and a dichotomous key is provided. New floral records for species of Chlerogella include Psychotria pongoana Standl. (Rubiaceae) and a putative record on Phragmopedium longifolium (Warsz. \& Rchb.f.) Rolfe (Orchidaceae).
\end{abstract}

Copyright Michael S. Engel. This is an open access article distributed under the terms of the Creative Commons Attribution License, which permits unrestricted use, distribution, and reproduction in any medium, provided the original author and source are credited. 


\section{Keywords}

Andes, Apoidea, Anthophila, Halictinae, Augochlorini, taxonomy, new species, identification key

\section{Introduction}

The neotropical bee genus Chlerogella Michener is a rarely encountered representative of the halictid tribe Augochlorini. The genus was originally described on the basis of a single female from central Panamá (Michener 1954; Engel 2009a) although Enderlein (1903) had described species many years earlier although in the genus Halictus Latreille, as was common practice for most halictines at the time. Indeed, Vachal (1901) likely may have described the first Chlerogella, also under Halictus (vide infra), although the identity of his species remains to be confirmed. Most species of the genus are most readily recognized by their elongate heads (e.g., Fig. 1), resembling in this respect species of the genera Chlerogas Vachal (1904; Brooks and Engel 1999; Engel et al. 2006; Engel and Gonzalez 2009; Engel 2009b, 2010), Chlerogelloides Engel et al. (1997; Engel and Brooks 1999), Rhynchochlora Engel (2007a), and some species of Ischnomelissa Engel (1997; Brooks and Engel 1998; Engel and Brooks 2002). Presently 55 species are known from these five genera (Table 1), nearly $90 \%$ of which have been described in the last 15 years.

Unfortunately, almost nothing is known of Chlerogella biology. Dodson (1965) mentioned an unidentified "Chlerogella" as visiting the orchid Phragmopedium longifolium (Warsz. \& Rchb.f.) Rolfe in Perú. It is unknown whether this identification is correct as the genus could be confused with superficially similar genera such as Caenohalictus Cameron, Ischnomelissa, or even Chlerogas. If indeed a Chlerogella, then it is further unknown which Peruvian species this might have been. Engel (2003a) recorded Chlerogella clidemiae Engel as visiting a species of Clidemia crenulata Gleason (Melastomataceae), but it is not known whether the individual was collecting pollen or simply obtaining nectar. A similar association with Psychotria pongoana Standl. (Rubiaceae) is documented here. The elongate heads of most species are a presumed adaptation for tubular flowers but this has yet to be confirmed by field observations.

Herein I provide a review of those species currently recognized in the genus, expanding the formerly documented South American diversity of five species to 27, ranging from Bolivia to Colombia and Venezuela (Maps 1-5). A further seven taxa are known from the Central American fauna (Engel 2009a) raising Chlerogella diversity to 34 described species. Given the rarity with which individuals have been collected and the large regions of suitable habitat between such collection localities, further species will undoubtedly be discovered. 


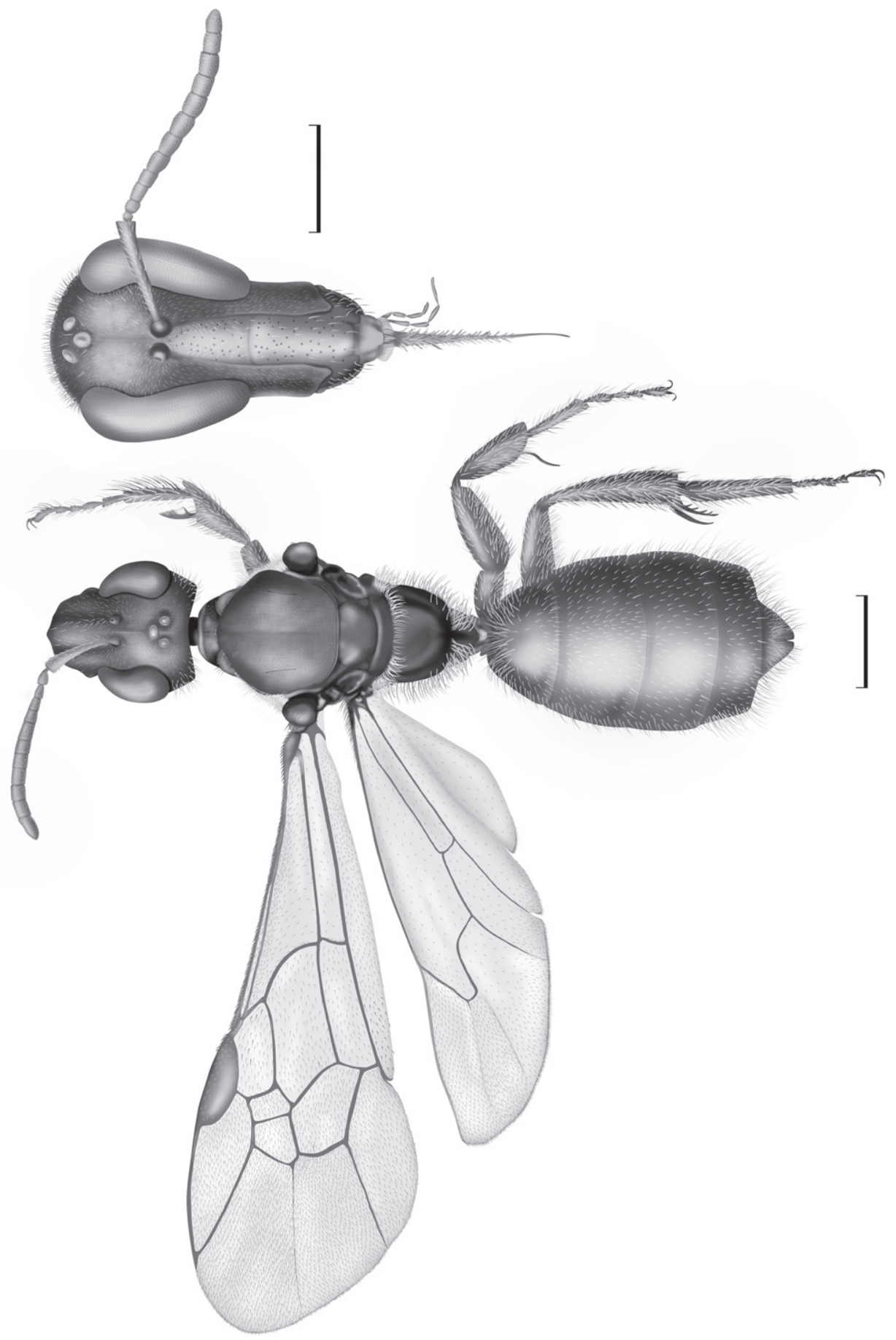

Figure I. Habitus illustration of Chlerogella rostrata sp. n. from Perú; dorsal aspect with legs removed from left side and wings from the right; facial detail inset. Scale bars $=1 \mathrm{~mm}$. 
Table I. Described diversity of the bee genera Chlerogas, Chlerogella, Chlerogelloides, Ischnomelissa, and Rhynchochlora; double asterisks $\left(^{(*)}\right.$ denote species within the variable genera Chlerogella and Ischnomelissa that do not have especially elongate heads. The status of C.? buyssoni (Vachal), from Perú, remains unresolved.

\begin{tabular}{|c|c|c|c|}
\hline Taxon & Sex & Elevation & Countries recorded \\
\hline \multicolumn{4}{|l|}{ Genus Chlerogas Vachal } \\
\hline C. araguaensis Brooks \& Engel & $\hat{\sigma}$ & $2000 \mathrm{~m}$ & Venezuela \\
\hline C. aterrimus Engel & q & $1800-2030 \mathrm{~m}$ & Bolivia \\
\hline C. boliviensis Brooks \& Engel & q & $2000-2030 \mathrm{~m}$ & Bolivia \\
\hline C. colombiensis Brooks \& Engel & $\hat{0}$ & est. $2100 \mathrm{~m}$ & Colombia \\
\hline C. cooperi Engel et al. & qo & $2100 \mathrm{~m}$ & Ecuador \\
\hline C. cyaneus Brooks \& Engel & q $\hat{O}$ & $2000-2400 \mathrm{~m}$ & Colombia, Ecuador \\
\hline C. chlerogas (Vachal) & q & $1900 \mathrm{~m}$ & Perú \\
\hline C. hirsutipennis Cockerell & $\hat{\sigma}$ & est. $2200 \mathrm{~m}$ & Perú \\
\hline C. nephos Brooks \& Engel & $q$ & est. $1500 \mathrm{~m}$ & Colombia \\
\hline C. tatamaensis Engel \& Gonzalez & $\hat{\sigma}$ & $2430 \mathrm{~m}$ & Colombia \\
\hline C. tiara Brooks \& Engel & +人 & $1200 \mathrm{~m}$ & Venezuela \\
\hline C. townesi Brooks \& Engel & q) & $1510-2400 \mathrm{~m}$ & Venezuela \\
\hline \multicolumn{4}{|l|}{ Genus Chlerogella Michener } \\
\hline C. agaylei sp. n. & q $\hat{O}$ & - & Ecuador \\
\hline C. anthonoma Engel & $\hat{0}$ & $400 \mathrm{~m}$ & Costa Rica \\
\hline C. arhyncha sp. n. ${ }^{* *}$ & +0 & $1300-1500 \mathrm{~m}$ & Perú \\
\hline C. azurea (Enderlein) & $q \hat{0}$ & $620-1200 \mathrm{~m}$ & Ecuador, Perú \\
\hline C. borysthenis sp. $\mathbf{n}$. & q & $1300 \mathrm{~m}$ & Ecuador \\
\hline C. breviceps sp. n.** & $q$ & $1000 \mathrm{~m}$ & Ecuador \\
\hline C.? buyssoni (Vachal) & q & unknown & Perú \\
\hline C. clidemiae Engel & q & $350 \mathrm{~m}$ & Panamá \\
\hline C. cochabambensis sp. $\mathbf{n}$. & q) & $1400-1480 \mathrm{~m}$ & Bolivia \\
\hline C. cooperella sp. $\mathbf{n}$. & $\hat{0}$ & $1100 \mathrm{~m}$ & Ecuador \\
\hline C. cyranoi sp. $\mathbf{n}$. & $\delta$ & - & Colombia \\
\hline C. dolichorhina sp. n. & $q$ & - & Ecuador \\
\hline C. elongaticeps Michener & qô & $800-860 \mathrm{~m}$ & Panamá \\
\hline C. elysia sp. n. & $+\hat{0}$ & $760-1300 \mathrm{~m}$ & Ecuador \\
\hline C. eumorpha sp. n. & q & $1100-1450 \mathrm{~m}$ & Ecuador \\
\hline C. euprepia sp. n. & $q$ & $300-1200 \mathrm{~m}$ & Ecuador \\
\hline C. fortunaensis Engel & $\sigma^{\pi}$ & $1050 \mathrm{~m}$ & Panamá \\
\hline C. hauseri sp. $\mathbf{n}$. & $\delta$ & $1685 \mathrm{~m}$ & Bolivia \\
\hline C. hypermeces sp. $\mathbf{n}$. & q) & $400-1100 \mathrm{~m}$ & Colombia, Ecuador \\
\hline C. kellieae Engel & qo & $700-1050 \mathrm{~m}$ & Costa Rica \\
\hline C. materdonnae sp. $\mathbf{n}$. & $+0^{\pi}$ & $1100 \mathrm{~m}$ & Ecuador \\
\hline C. mourella Engel & q & $2300 \mathrm{~m}$ & Ecuador \\
\hline C. nasus (Enderlein) & $q$ & $1000-1120 \mathrm{~m}$ & Perú \\
\hline C. octogesima (Brooks \& Engel) & $\hat{0}$ & - & Ecuador \\
\hline C. oresbios sp. $\mathbf{n}$. & $q \hat{0}$ & $1000-1500 \mathrm{~m}$ & Venezuela \\
\hline C. picketti sp. n. & $\hat{0}$ & $40 \mathrm{~m}$ & Colombia \\
\hline C. pinocchio Engel & $\hat{\sigma}$ & $700 \mathrm{~m}$ & Costa Rica \\
\hline
\end{tabular}




\begin{tabular}{|c|c|c|c|}
\hline Taxon & Sex & Elevation & Countries recorded \\
\hline C. prolixa Engel & +क्र & $1250-1380 \mathrm{~m}$ & Panamá \\
\hline C. rostrata $\mathbf{s p .} \mathbf{n}$. & q & $1300-1500 \mathrm{~m}$ & Ecuador \\
\hline C. silvula sp. n. & $\hat{\sigma}$ & $500 \mathrm{~m}$ & Ecuador \\
\hline C. terpsichore sp. $\mathbf{n}$. & की & $40 \mathrm{~m}$ & Colombia \\
\hline C. tychoi sp. n. & q & $560 \mathrm{~m}$ & Colombia \\
\hline C. vachali sp. n.** & q & $480 \mathrm{~m}$ & Perú \\
\hline C. xuthopleura sp. $\mathbf{n}$. & $\hat{\sigma}$ & $1000 \mathrm{~m}$ & Venezuela \\
\hline \multicolumn{4}{|c|}{ Genus Chlerogelloides Engel et al. } \\
\hline C. femoralis Engel et al. & $q \hat{0}$ & $270-400 \mathrm{~m}$ & Brazil, Colombia, Ecuador, Perú \\
\hline C. simplex Engel \& Brooks & q0 & $200-280 m$ & French Guiana \\
\hline \multicolumn{4}{|l|}{ Genus Ischnomelissa Engel } \\
\hline I. cyanea Brooks \& Engel ${ }^{* *}$ & q & $2200 \mathrm{~m}$ & Colombia \\
\hline I. ecuadoriana Brooks \& Engel & $\delta$ & $2200 \mathrm{~m}$ & Ecuador \\
\hline I. lescheni Brooks \& Engel ${ }^{* *}$ & q⿳亠口冋 & $1000-1750 \mathrm{~m}$ & Ecuador \\
\hline I. rasmusseni Engel \& Brooks & q & $2152 \mathrm{~m}$ & Ecuador \\
\hline I. rhina Brooks \& Engel & q & $2300-2600 \mathrm{~m}$ & Ecuador \\
\hline I. zonata Engel** & qर्र & $1800-2000 \mathrm{~m}$ & Colombia \\
\hline \multicolumn{4}{|l|}{ Genus Rhynchochlora Engel } \\
\hline R. chlerogopsis Engel & $q$ & $1450 \mathrm{~m}$ & Ecuador \\
\hline
\end{tabular}

\section{Material and methods}

Material for this study slowly accumulated over the last 16 years. For a long time after the description of the genus the only known specimen was the holotype of C. elongaticeps Michener, although two species described in Halictus by Enderlein (1903) subsequently were discovered to be Chlerogella and one species described by Vachal (1901) putatively belongs to the genus (vide infra). By the early 1990s when I began studying the tribe approximately 40 specimens had been located. This number grew slowly but steadily with each passing year, often consisting of new species which retarded completion of the project. Within the last couple of years additional material has been rare and, when the odd specimen or two has appeared, usually has consisted of species already known among those described herein. Accordingly, it seemed an appropriate time to finalize the keys and submit the manuscript. Excluding the Central American fauna which was treated elsewhere (Engel, 2009a), a total of 151 South American specimens $(80 q 9,71 \hat{\jmath})$ were found and studied from the following collections:

AMNH Division of Invertebrate Zoölogy, American Museum of Natural History, New York, New York, USA.

BLCU Bee Biology and Systematics Laboratory, USDA-ARS, Utah State University, Logan, Utah, USA.

CNC Canadian National Collection, Ottawa, Ontario, Canada. 
COOP Martin Cooper collection, Wiltshire, UK (eventually to be deposited in the Natural History Museum, London).

CSCA California State Collection of Arthropods, Sacramento, California, USA.

CUIC Cornell University Insect Collection, Ithaca, New York, USA.

MEFLG Museo Entomologico Francisco Luis Gallego, Universidad National de Colombia, Sede Medellin, Colombia.

MIZA Museo del Instituto de Zoología Agrícola, Universidad Central de Venezuela, Maracay, Venezuela.

MUSM Museo de Historia Natural, Universidad Nacional Mayor de San Marcos, Lima, Perú.

MZSP Museu de Zoologia da Universidade de São Paulo, São Paulo, Brazil.

PMAE Provincial Museum of Alberta, Edmonton, Alberta, Canada.

QCAZ Quito Catholic Zoology Museum, Departamento de Biologia, Pontifica Universidad Catolica del Ecuador, Quito, Ecuador.

SEMC Division of Entomology (Snow Entomological Collection), University of Kansas Natural History Museum, Lawrence, Kansas, USA.

UMMZ Museum of Zoology, University of Michigan, Ann Arbor, Michigan, USA.

USNM Department of Entomology, National Museum of Natural History (United States National Museum), Smithsonian Institution, Washington, D.C., USA.

YORK Bee Collection, York University, Toronto, Canada.

ZMHB Museum für Naturkunde der Humboldt-Universität, Berlin, Germany.

Morphological terminology for this study follows that of Michener $(1944,2007)$ and Engel (2000, 2001, 2007b, 2009a), particularly replacement of metatibial spur "teeth" with "branches" arising from the "rachis" as advocated by Engel (2009a). The abbreviations $S$ and $T$ are used in place of metasomal sternum and tergum, respectively. The format for the descriptions is generally taken from that used elsewhere in Augochlorini (e.g., Engel 2009a) except some standard metrics are herein removed to Table 2. Measurements were prepared using an ocular micrometer on an Olympus SZX-12 stereomicroscope and are summarized in that table along with other metrics for each species. The head length was calculated by measuring from the vertex to the apex of the clypeus, head width from the maximum outer borders of the compound eyes, and total body length by measuring the individual lengths of the head, mesosoma, and metasoma and summing the values.

Species accounts are organized geographically by country beginning with the Bolivian fauna and then proceeding northward to Colombia and Venezuela. An index to specific epithets is provided at the end of the monograph for more ready access to the descriptions and figures of individual taxa. 
Table 2. Comparison of head metrics across South American species of Chlerogella; values in millimeters where appropriate; ML vs. MB is the malar length as a function of the number of times the basal mandibular width; the abbreviation F is used for flagellomere and FII vs. FI is the length of the second flagellomere as a function of the number of times the length of the first flagellomere (such proportion is only indicated for males where there is significant variation). n.a. = not applicable. For sample sizes see material examined under each species.

\begin{tabular}{|c|c|c|c|c|c|c|c|}
\hline Species & $\begin{array}{l}\text { Head } \\
\text { length }\end{array}$ & $\begin{array}{l}\text { Head } \\
\text { width }\end{array}$ & $\begin{array}{l}\text { Malar } \\
\text { length }\end{array}$ & \begin{tabular}{|l|} 
Eye \\
length
\end{tabular} & $\begin{array}{l}\text { Malar- } \\
\text { Eye \% }\end{array}$ & \begin{tabular}{|l|} 
ML \\
vs. \\
MB
\end{tabular} & \begin{tabular}{|l|} 
F II \\
vs. \\
FI \\
\end{tabular} \\
\hline \multicolumn{8}{|c|}{ Females $(+)$} \\
\hline C. agaylei sp. $\mathrm{n}$. & 2.45 & 1.54 & 0.60 & 1.34 & $44.8 \%$ & $3.8 \times$ & n.a. \\
\hline C. arhnycha sp. n. & 1.90 & 1.67 & 0.026 & 1.38 & $1.9 \%$ & $0.12 \times$ & n.a. \\
\hline C. azurea (Enderlein) & $2.39-2.50$ & $1.40-1.46$ & $0.55-0.56$ & $1.33-1.34$ & $41.4-41.8 \%$ & $3.4 \times$ & n.a. \\
\hline C. borysthenis sp. $\mathrm{n}$. & 2.16 & 1.93 & 0.10 & 1.54 & $6.8 \%$ & $0.5 x$ & n.a. \\
\hline C. breviceps sp. $\mathrm{n}$. & 1.82 & 1.51 & 0.13 & 1.25 & $10.4 \%$ & $0.72 \times$ & n.a. \\
\hline C. cochabambensis sp. $\mathrm{n}$. & $2.60-2.66$ & $1.69-1.77$ & $0.52-0.53$ & $1.47-1.51$ & $34.4-35.8 \%$ & $2.5 x$ & n.a. \\
\hline C. dolichorhina sp. n. & 2.71 & 1.69 & 0.68 & 1.48 & $45.9 \%$ & $3.8 \times$ & n.a. \\
\hline C. elysia sp. n. & $2.32-2.35$ & $1.63-1.72$ & $0.23-0.24$ & $1.46-1.48$ & $16.4-17.6 \%$ & $1.3 \times$ & n.a. \\
\hline C. eumorpha sp. n. & $2.29-2.30$ & $1.69-1.71$ & 0.26 & $1.47-1.48$ & $17.6-17.7 \%$ & $1.1 \times$ & n.a. \\
\hline C. euprepia sp. n. & $2.69-2.71$ & $1.82-1.83$ & 0.68 & $1.51-1.52$ & $44.8-45.0 \%$ & $3.2 \times$ & n.a. \\
\hline C. hypermeces sp. n. & $3.07-3.23$ & $1.80-1.88$ & $1.03-1.07$ & $1.57-1.64$ & $65.2-66.0 \%$ & $5.1 \times$ & n.a. \\
\hline C. materdonnae sp. n. & 2.71 & 1.74 & 0.65 & 1.48 & $43.9 \%$ & $3.6 x$ & n.a. \\
\hline C. mourella Engel & 2.44 & 1.84 & 0.30 & 1.58 & $19.0 \%$ & $1.3 \times$ & n.a. \\
\hline C. nasus (Enderlein) & $2.58-2.60$ & $1.76-1.78$ & $0.52-0.55$ & $1.46-1.48$ & $35.6-37.2 \%$ & $2.4 \times$ & n.a. \\
\hline C. oresbios sp. n. & $2.35-2.37$ & $1.56-1.64$ & $0.39-0.42$ & 1.48 & $26.3-28.4 \%$ & $\begin{array}{l}2.3- \\
2.5 \times\end{array}$ & n.a. \\
\hline C. rostrata sp. n. & $2.73-2.75$ & $1.88-1.91$ & $0.60-0.61$ & $1.56-1.58$ & $38.5-38.6 \%$ & $2.9 \times$ & n.a. \\
\hline C. terpsichore sp. n. & $2.35-2.36$ & $1.55-1.57$ & $0.43-0.44$ & $1.39-1.41$ & $30.9-31.1 \%$ & $2.0 x$ & n.a. \\
\hline C. tychoi sp. n. & 2.45 & 1.56 & 0.68 & 1.43 & $47.6 \%$ & $4.3 \times$ & n.a. \\
\hline C. vachali sp. n. & 1.64 & 1.30 & 0.078 & 1.09 & $7.2 \%$ & $0.4 x$ & n.a. \\
\hline \multicolumn{8}{|c|}{ Males $\left({ }^{\Uparrow}\right)$} \\
\hline C. agaylei sp. n. & 2.55 & 1.54 & 0.63 & 1.35 & $46.7 \%$ & $3.8 \times$ & $2.0 \mathrm{x}$ \\
\hline C. arhyncha sp. n. & $1.67-1.70$ & $1.51-1.53$ & 0.026 & $1.22-1.23$ & $2.1 \%$ & $0.2 \times$ & $2.0 \mathrm{x}$ \\
\hline C. azurea (Enderlein) & $2.42-2.45$ & $1.33-1.36$ & 0.60 & $1.25-1.26$ & $47.6-48.0 \%$ & $3.8 \times$ & $2.0 \mathrm{x}$ \\
\hline C. cochabambensis sp. $\mathrm{n}$. & $2.63-2.67$ & $1.61-1.67$ & $0.63-0.65$ & $1.39-1.41$ & $45.3-46.1 \%$ & $4.5 \times$ & $3.0 \mathrm{x}$ \\
\hline C. cooperella sp. n. & $2.08-2.10$ & $1.41-1.42$ & 0.23 & 1.30 & $17.7 \%$ & $1.3 \times$ & $3.4 \mathrm{x}$ \\
\hline C. cyranoi sp. n. & 2.42 & 1.48 & 0.65 & 1.28 & $50.7 \%$ & $4.6 x$ & $2.2 \mathrm{x}$ \\
\hline C. elysia sp. n. & $2.30-2.48$ & $1.59-1.63$ & $0.26-0.29$ & $1.44-1.46$ & $18.0-19.9 \%$ & $1.6 x$ & $2.4 \mathrm{x}$ \\
\hline C. eumorpha sp. n. & $2.24-2.32$ & $1.56-1.61$ & 0.26 & $1.46-1.48$ & $17.6-17.8 \%$ & $1.3 \times$ & $3.4 \mathrm{x}$ \\
\hline C. hauseri sp. n. & $3.39-3.54$ & $1.74-1.85$ & $1.02-1.04$ & $1.61-1.72$ & $59.3-64.6 \%$ & $\begin{array}{l}5.6- \\
5.7 x\end{array}$ & $3.0 \mathrm{x}$ \\
\hline C. hypermeces sp. n. & $3.15-3.30$ & $1.63-1.83$ & $1.07-1.10$ & $1.54-1.58$ & $69.5-70.0 \%$ & $6.3 \times$ & $3.4 \mathrm{x}$ \\
\hline C. materdonnae sp. n. & $2.58-2.60$ & $1.59-1.60$ & 0.73 & $1.43-1.44$ & $50.7-51.0 \%$ & $4.6 x$ & $2.4 \mathrm{x}$ \\
\hline $\begin{array}{l}\text { C. octogesima } \\
\text { (Brooks \& Engel) }\end{array}$ & 1.73 & 1.19 & 0.14 & 1.15 & $12.2 \%$ & $1.0 x$ & $2.5 \mathrm{x}$ \\
\hline C. oresbios sp. n. & $2.50-2.53$ & $1.64-1.66$ & 0.44 & $1.51-1.54$ & $28.6-29.1 \%$ & $2.6 x$ & $3.0 \mathrm{x}$ \\
\hline C. picketti sp. n. & 2.16 & 1.56 & 0.26 & 1.38 & $18.8 \%$ & $1.6 x$ & $3.0 \mathrm{x}$ \\
\hline C. silvula sp. n. & $1.74-1.80$ & $1.25-1.28$ & $0.13-0.16$ & $1.12-1.15$ & $11.6-13.9 \%$ & $1.2 \times$ & $2.8 \mathrm{x}$ \\
\hline C. terpsichore sp. n. & $2.37-2.41$ & $1.57-1.60$ & $0.43-0.44$ & $1.41-1.42$ & $30.5-31.0 \%$ & $2.1 \times$ & $2.0 \mathrm{x}$ \\
\hline C. xuthopleura sp. n. & $2.32-2.42$ & $1.59-1.64$ & $0.44-0.47$ & $1.41-1.46$ & $31.2-32.2 \%$ & \begin{tabular}{|l|}
$3.1-$ \\
$3.5 \times$ \\
\end{tabular} & $3.0 \mathrm{x}$ \\
\hline
\end{tabular}




\section{Systematics}

\section{Genus Chlerogella Michener}

Chlerogella Michener, 1954: 75. Type species: Chlerogella elongaticeps Michener, 1954, by original designation and monotypy. Eickwort, 1969: 445; Engel, 1998: 110; Engel, 2000: 38; Michener, 2000: 389; González et al., 2005: 50; Michener, 2007: 405; Smith-Pardo and Vélez-Ruiz, 2008: 57.

Diagnosis. Female: Head longer than wide; mandible with weakly to moderately developed subapical tooth; labral distal process narrowly triangular; basal elevation orbicular to bilobed; lateral teeth absent; prementum not greatly elongate, less than seven times longer than wide; galeal apex lobed; galeal comb absent; galeal base reaching back to stipital base; hypostomal ridge carinate to lamellate; anterior angle rounded; malar length usually much longer than basal width of mandible although in a few species the malar space is as long as to much shorter than basal mandibular width (vide infra); epistomal sulcus acute to nearly orthogonal; ocelli not greatly enlarged; ocellar furrow absent; vertex not expanded or ridged behind ocelli; preoccipital ridge rounded. Pronotal dorsal surface typically unmodified from most genera with dorsal ridge rounded and medially overlapped by mesoscutum (rarely inflated between lateral portions of pronotal dorsal surface so that there is a long horizontal surface with a gently rounded anterior edge dropping down onto pronotal collar); lateral ridge entirely absent; mesoscutal anterior border rounded; tegula oval; prosternum expanded, pushing posterior corners of propleurae and anterior corners of procoxae apart. Probasitarsal brush present; metabasitibial plate bordered on all sides, not strongly rimmed; inner metatibial spur with pectinate branches along rachis, with eight or fewer branches. Forewing marginal cell apex acute; hind wing with distal hamuli irregularly spaced (typically arranged 2-1-2 or 3-1-2). Basal area of propodeum as long as or longer than combined lengths of mesoscutellum and metanotum, weakly to strongly imbricate; propodeal pit narrow, not set into broad V-shaped notch.

Male: Mandible simple; labrum without distal process; antenna long, reaching back to anterior through posterior borders of propodeum; second flagellomere longer than first flagellomere. Inner metatibial spur typically serrate, rarely ciliate or pectinate with short, thin branches. Metasoma typically elongate; SVII and SVIII with medio-apical projections; spiculum present and narrow; ventral surface of penis valve with prong; parapenial lobe absent; basal process of gonostylus absent; dorsal process of gonostylus typically reduced, with variable development of setae (typically with thickened elongate setae branched at their apices); ventral gonostylar process typically elaborately developed, with numerous sometimes thickened setae forming patches or fringes (secondarily simplified in a few species).

Comments. Some of the features historically believed to be of critical importance for defining Chlerogella are now understood to be rare among the diversity of species. 
For instance, the long and convex pronotal dorsal surface in C. elongaticeps is rare in the genus and does not fully characterize the clade. Similarly, the elongate malar space, while common across the genus, is not universal. Some of the more important characters that do hold are the elongate propodeum lacking striae or granular integument, the complete absence of the pronotal lateral ridge, a head that is longer than wide, a pectinate inner metatibial spur with eight or fewer branches, and an acute marginal cell. The related genus Chlerogelloides differs in that its species have a strongly acute epistomal sulcus that projects deeply into the clypeus as a thin lobe nearly reaching the clypeal apex and has a serrate inner metatibial spur in females, and a strongly doublecurved simple mandible, a shorter antenna, and the first flagellomere longer than the second in males. From Ischnomelissa the genus differs in the fewer branches of the inner metatibial spur (10 or more densely packed branches in Ischnomelissa) in females and the more elaborately developed gonostylar processes in males. All three of these genera share an expanded, diamond-shaped prosternum. In addition, the elongate propodeum lacking striae is common to these genera and the species of Chlerogelloides share with at least $C$. elongaticeps the inflated pronotal dorsal surface.

Distribution. The genus is distributed in the Andean region from Bolivia, through Perú and Ecuador, into Colombia, from there across to Venezuela (Maps 1-5), and northward into Central America as far North as Guanacaste Province, Costa Rica (refer to maps in Engel 2009a).

Floral records. Melastomataceae: Clidemia crenulata Gleason (C. clidemiae Engel); Orchidaceae: Phragmopedium longifolium (Warsz. \& Rchb.f.) Rolfe (Orchidaceae) (Chlerogella sp., identification of bee has not been confirmed as the material upon which the determination was made is unknown); Rubiaceae: Psychotria pongoana Standl. (C. hypermeces sp. n.). One label of a female of C. oresbios collected in Venezuela indicates the specimen was captured at flowers of "Corupelis". I have not been able to determine what plant genus this was intended to correspond to.

\section{Chlerogella cochabambensis Engel, sp. n.}

urn:Isid:zoobank.org:act:34A1F730-A468-4EFC-AA3A-BAF5D4A5045F

Figs 2-8, 14-15, Map 1

Holotype. + , Bolrvia: Cochabamba [Department], Cochabamba, 109 km E Yungas (Cochabamba - Villa Tunari Rd.), 1480 m, 170'50"S, 6542'29"W, 8-12 February 1999, R. Hanley, ex: flight intercept trap (SEMC).

Paratypes. Bolivia: 1 , Cochabamba [Department], Cochabamba, $109 \mathrm{~km} \mathrm{E}$

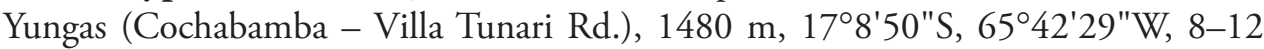
February 1999, R. Hanley, ex: flight intercept trap (SEMC); $3+$ 우 $10^{\Uparrow}$, Cochabamba [Department], Cochabamba, $109 \mathrm{~km}$ E Yungas (Cochabamba - Villa Tunari Rd.), $1480 \mathrm{~m}, 1^{\circ} 8^{\prime} 50^{\prime} \mathrm{S}, 6^{\circ} 42^{\prime} 29^{\prime \prime W}, 1-6$ February 1999, F. Genier, ex: flight intercept trap (SEMC); 1ㅇ, Cochabamba [Department], Cochabamba, $109 \mathrm{~km}$ E Yungas (Cochabamba - Villa Tunari Rd.), 1480 m, 1708'50"S, 6542'29"W, 1-6 Feb- 


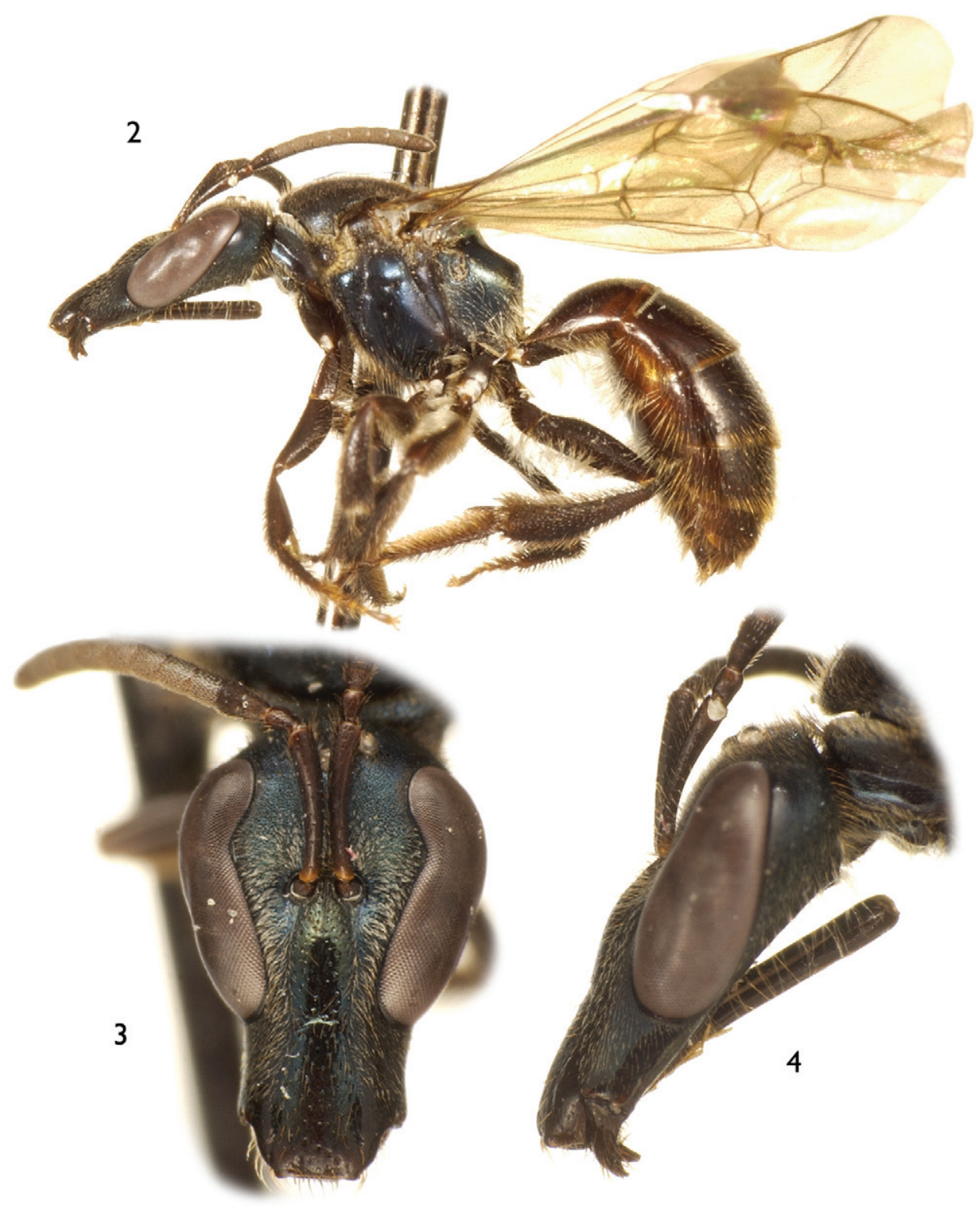

Figures 2-4. Female of Chlerogella cochabambensis sp. n. 2 Lateral habitus 3 Facial aspect $\mathbf{4}$ Lateral aspect of head.

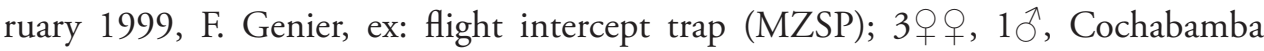
[Department], Cochabamba, $109 \mathrm{~km}$ E Yungas (Cochabamba - Villa Tunari Rd.), $1400 \mathrm{~m}, 17^{\circ} 8^{\prime} 52^{\prime \prime S}, 65^{\circ} 42^{\prime} 54^{\prime \prime W}, 8-12$ February 1999, F. Genier, ex: flight intercept trap (SEMC); 1 + , Prov. La Paz, Cumbre Alto Beni, vicinity of Caranavi, 1685 m, 1540'19"S, 67²9'35"W, 7-15.iv.2004 [7-15 April 2004], malaise traps, S.D. Gaimari \& M. Hauser (CSCA). 


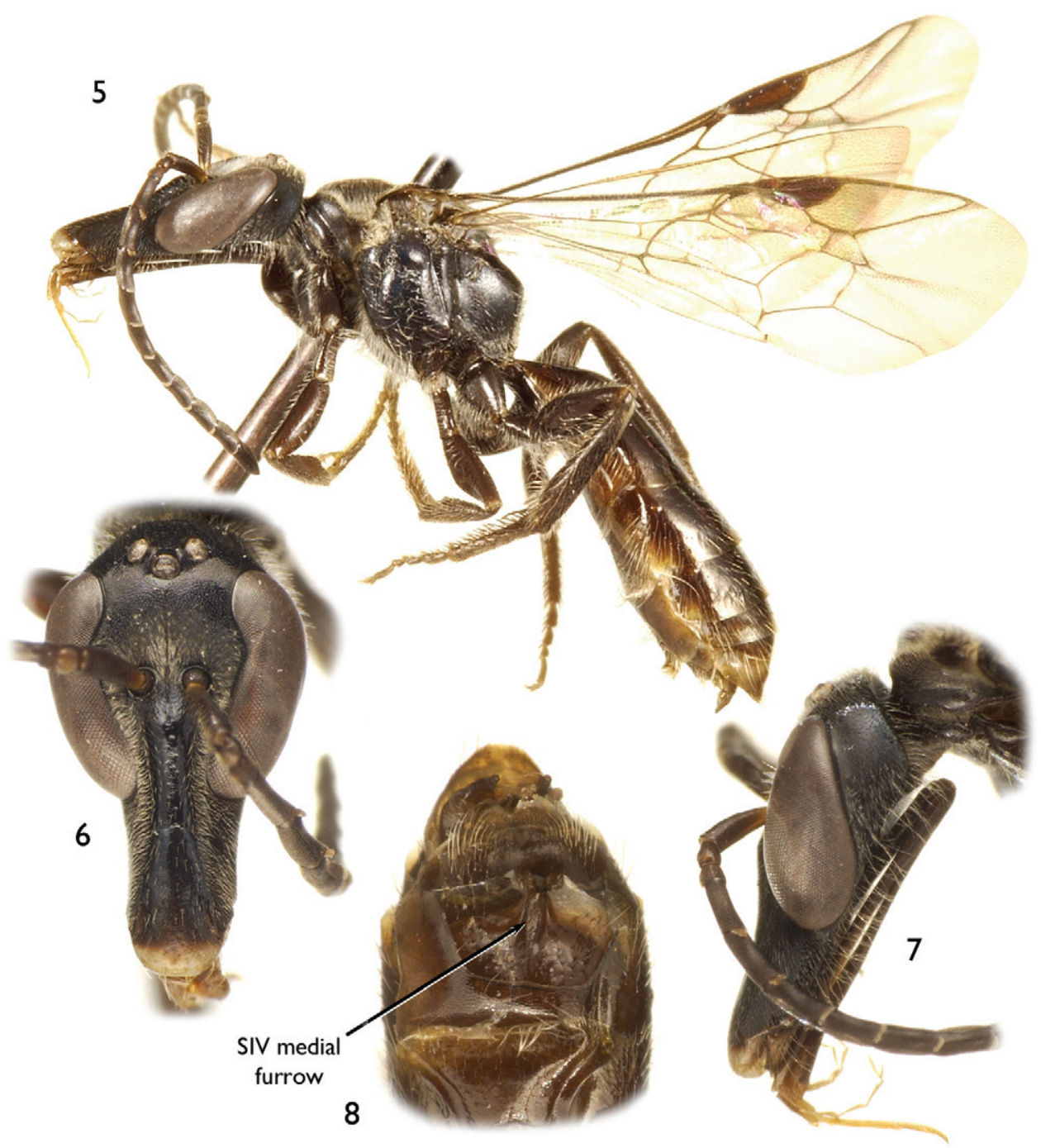

Figures 5-8. Male of Chlerogella cochabambensis sp. n. 5 Lateral habitus 6 Facial aspect 7 Lateral aspect of head $\mathbf{8}$ Apical sterna of metasoma.

Diagnosis. Chlerogella cochabambensis is most similar to C. oresbios from Venezuela (vide infra). The former can be distinguished by the more dull and muted coloration, the more closely punctured mesoscutum, the distinct arching of 2rs-m in the forewing, the structure of the SIV and terminalia in males (Figs 8, 14-15), and the slightly larger body size.

Description. Female: Total body length $8.94-9.43 \mathrm{~mm}$; forewing length $6.37-$ $6.40 \mathrm{~mm}$. Head length $2.60-2.66 \mathrm{~mm}$, width $1.69-1.77 \mathrm{~mm}$. Clypeus beginning just below lower tangent of compound eyes (Fig. 3). Malar space $34.4-35.8 \%$ compound eye length (malar length $0.52-0.53 \mathrm{~mm}$; compound eye length $1.47-1.51 \mathrm{~mm}$ ) 


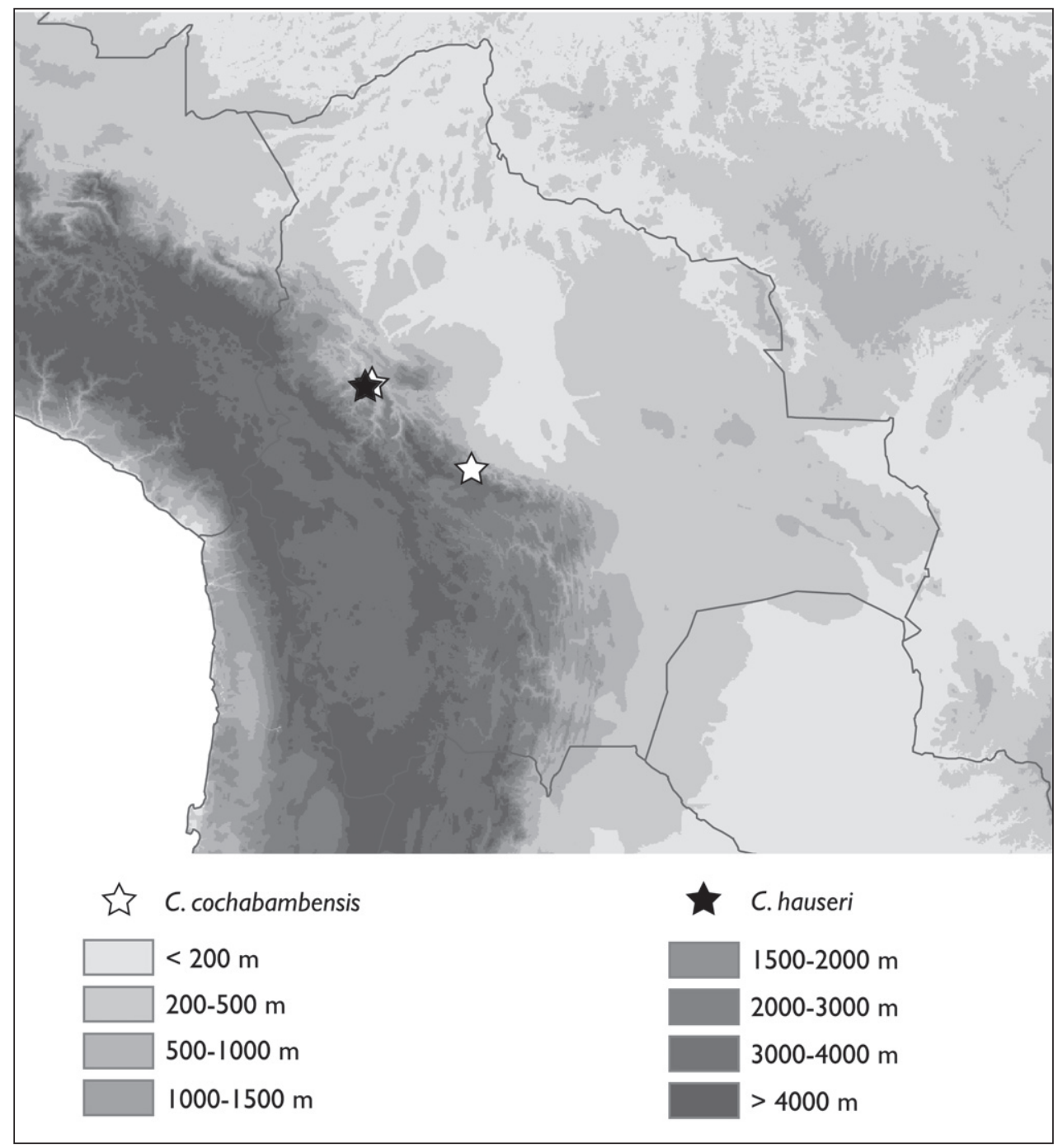

Map I. Collection localities for Bolivian Chlerogella.

(Figs. 3-4). Upper interorbital distance $0.87-0.89 \mathrm{~mm}$; lower interorbital distance 0.63-0.65 mm. Upper portion of pronotum medially depressed, not elongate, medially less than 0.25 times ocellar diameter in length; ventral portion of preëpisternal sulcus not broad, similar to scrobal sulcus and upper portion of preëpisternal sulcus; intertegular distance 1.38-1.43 mm; mesoscutellum weakly convex, not bigibbous. Basal vein distad cu-a by three times vein width; $1 \mathrm{rs}-\mathrm{m}$ distad $1 \mathrm{~m}$-cu by three times vein width; $2 \mathrm{rs}-\mathrm{m}$ distad $2 \mathrm{~m}$-cu by six times vein width, $2 \mathrm{rs}-\mathrm{m}$ gently arched; first submarginal cell longer than combined lengths of second and third submarginal cells; second submarginal cell not narrowed anteriorly, anterior border of second submarginal cell along Rs about as along as that of third submarginal cell; posterior border of 
third submarginal cell slightly more than two times longer than anterior border. Distal hamuli arranged 2-1-2. Inner metatibial spur with six branches (not including apical portion of rachis).

Clypeus and supraclypeal area imbricate with weak punctures separated by 1-2 times a puncture width; face with small, contiguous punctures, more widely spaced in malar space; punctures of face blending to faintly imbricate integument in ocellocular area and vertex, with punctures separated by a puncture width; gena smooth with small punctures separated by 1-2 times a puncture width; postgena imbricate and impunctate. Pronotum imbricate with minute punctures separated by $1-3$ times a puncture width; mesoscutum imbricate with small punctures separated by a puncture width or less on lateral thirds and along posterior border, medially punctures separated by $1-1.5$ times a puncture width, anteromedially punctures becoming exceedingly faint to absent; mesoscutellum faintly imbricate with small punctures separated by a puncture width or less; metanotum imbricate with minute punctures separated by a puncture width or less. Preëpisternum faintly imbricate with small punctures separated by $1-3$ times a puncture width; mesepisternum weakly imbricate with small punctures separated by $2-6$ times a puncture width, punctures weak; metepisternum faintly imbricate. Propodeum strongly imbricate. Metasoma weakly imbricate.

Mandible dark brown except reddish at apex; labrum dark brown; clypeal apex black, remainder of clypeus and head dark, dull metallic blue, nearly black in some individuals. Antenna dark brown. Mesosoma dark, dull metallic blue, nearly dark brown or black in some individuals (Fig. 2); tegula dark brown. Wing membranes weakly infumate; veins dark brown. Legs dark brown except apical tarsomeres slightly lighter. Metasoma dark brown, with apical margins of terga translucent brown.

Pubescence white to slightly golden except intermingled with fuscous setae on mesoscutum, mesoscutellum, metanotum, TIV-VI, and SIV-VI, and dark fuscous to black on pro- and mesotibiae, pro- and mesotarsi, metatibia, and metatarsus.

Male: As described for the female except as follows: Total body length 9.43-9.74 $\mathrm{mm}$; forewing length $6.40-6.53 \mathrm{~mm}$. Head length $2.63-2.67 \mathrm{~mm}$, width $1.61-1.67$ $\mathrm{mm}$. Clypeus beginning below lower tangent of compound eyes (Fig. 6). Malar space 45.3-46.1\% compound eye length (malar length $0.63-0.65 \mathrm{~mm}$; compound eye length $1.39-1.41 \mathrm{~mm}$ ) (Figs 6-7). Upper interorbital distance $0.76-0.78 \mathrm{~mm}$; lower interorbital distance $0.45-0.47 \mathrm{~mm}$. First flagellomere about as long as pedicel, about as long as wide; second flagellomere three times length of first flagellomere; ventral surfaces of second through eleventh flagellomeres densely covered in placoid sensilla, placoid fields disrupted by narrow mediolongitudinal line of fine, minute trichoid sensilla for lengths of flagellomeres $\mathrm{V}-\mathrm{X}$ and apically on flagellomere IV. Intertegular distance $1.33-1.38 \mathrm{~mm}$; mesoscutellum weakly bigibbous. Inner metatibial spur serrate. Apical margin of SIII entire; apical margin of SIV weakly produced medioapically, with narrow concave emargination between setose lobes, with narrow shallow medio-longitudinal furrow in apical half of disc, not bordered by carinae (Fig. 8); apical margin of SV weakly concave; apical margin of SVI emarginate; terminalia as depicted in figures 14 and 15. 
Mandible, labrum, and clypeal apex white. Areas of dark, dull metallic blue in female darker in male, nearly black and with faint hints of blue (Fig. 5).

Typical gender pilosity except postgena with numerous elongate, sinuate setae, such setae with short apical branches; inner surfaces of trochanters, mesofemur, and metacoxa with elongate, apically-plumose setae, similar setae on inner surfaces of metatrochanter, metafemur, and metatibia except largely simple and somewhat sinuate, those of metatibia particularly elongate and sinuous at apices. Apical margin of SIII with diffuse fringe of moderate-length white setae; SIV with small medioapical pads of short golden to fuscous setae bordering medial emargination; SV laterally with diffuse areas of long, inwardly-curved setae.

Etymology. The specific epithet is taken from the Department of Bolivia in which the type series was collected.

\section{Chlerogella hauseri Engel, sp. n.}

urn:lsid:zoobank.org:act:32EA2B73-11BE-4094-B00D-7E808C483B64

Figs 9-13, 16-17, Map 1

Holotype. $\sigma^{\top}$, Bolrvia: Prov. La Paz, Cumbre Alto Beni, vicinity of Caranavi, 1685 m, 1540'19"S, 67²9'35"W, 15-21.iv.2004 [15-21 April 2004], malaise traps, S.D. Gaimari \& M. Hauser (CSCA).

Paratypes. Bolivia: $1 \hat{\jmath}$, Prov. La Paz, Cumbre Alto Beni, vicinity of Caranavi, $1685 \mathrm{~m}, 1^{\circ} 40^{\prime} 19^{\prime} \mathrm{S}, 67^{\circ} 29^{\prime} 35^{\prime \prime W}, 15-21 . i v .2004$ [15-21 April 2004], malaise traps, S.D. Gaimari \& M. Hauser (SEMC); $1 \delta^{\Uparrow}$, Prov. La Paz, Cumbre Alto Beni, vicinity of Caranavi, 1685 m, 1540'19"S, 67²9'35"W, 19.iv.2004 [19 April 2004], S.D. Gaim-

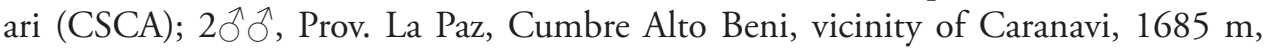
1540'19"S, 67²9'35"W, 7-15.iv.2004 [7-15 April 2004], malaise traps, S.D. Gaimari \& M. Hauser (CSCA); $1 \delta^{\AA}$, Prov. La Paz, Cumbre Alto Beni, vicinity of Caranavi, $1685 \mathrm{~m}, 15^{\circ} 40^{\prime} 19^{\prime \prime S}, 67^{\circ} 29^{\prime} 35^{\prime \prime W}, 7-15 . i v .2004$ [7-15 April 2004], malaise traps, S.D. Gaimari \& M. Hauser (SEMC).

Diagnosis. This is one of the largest species of Chlerogella currently known, sharing its prodigious size with its more northern cousin, C. hypermeces (vide infra). Chlerogella hauseri and $C$. hypermeces both approximate in size species of the superficially similar genus Chlerogas. Chlerogella hauseri can be distinguished by the combination of an extremely elongate head (Figs 9-11), a unique color pattern of the head and body (Figs 9, 11), a swollen metafemur (Fig. 12), the structure of the male SIV (Fig. 13) and terminalia (Figs 16-17).

Description. Male: Total body length $11.39-11.67 \mathrm{~mm}$; forewing length 7.53-7.87 $\mathrm{mm}$. Head length 3.39-3.54 mm, width 1.74-1.85 mm. Clypeus beginning below lower tangent of compound eyes (Fig. 11). Malar space 59.3-64.6\% compound eye length (malar length 1.02-1.04 mm; compound eye length 1.61-1.72 mm) (Figs. 10-11). Upper interorbital distance $0.78-0.83 \mathrm{~mm}$; lower interorbital distance $0.47-0.49 \mathrm{~mm}$. First flagellomere about as long as pedicel, about as long as wide; second flagellomere three 


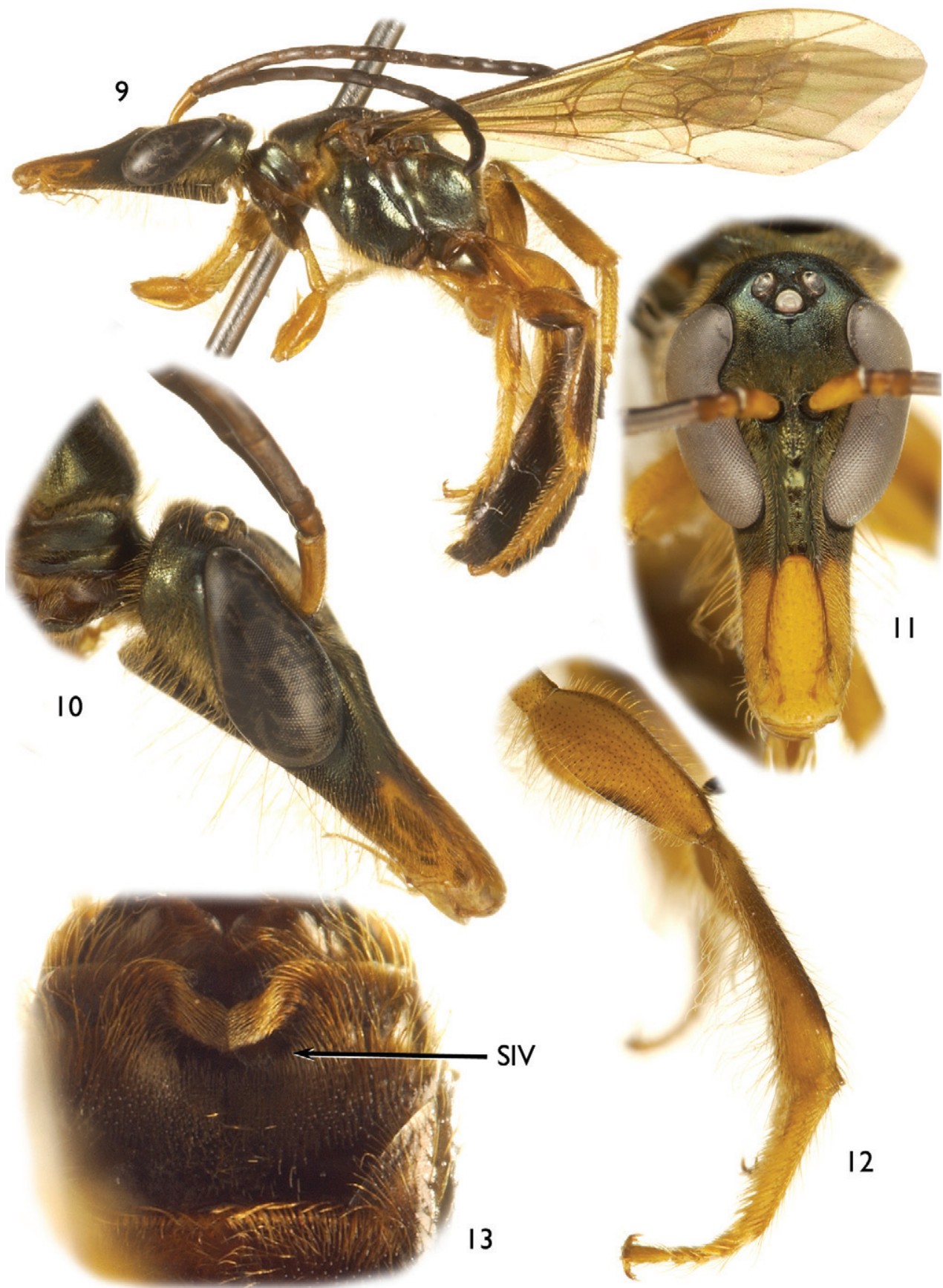

Figures 9-I3. Male of Chlerogella hauseri sp. n. 9 Lateral habitus 10 Lateral aspect of head I I Facial aspect $\mathbf{I} \mathbf{2}$ Hind leg $\mathbf{I} \mathbf{3}$ Apical sterna of metasoma. 

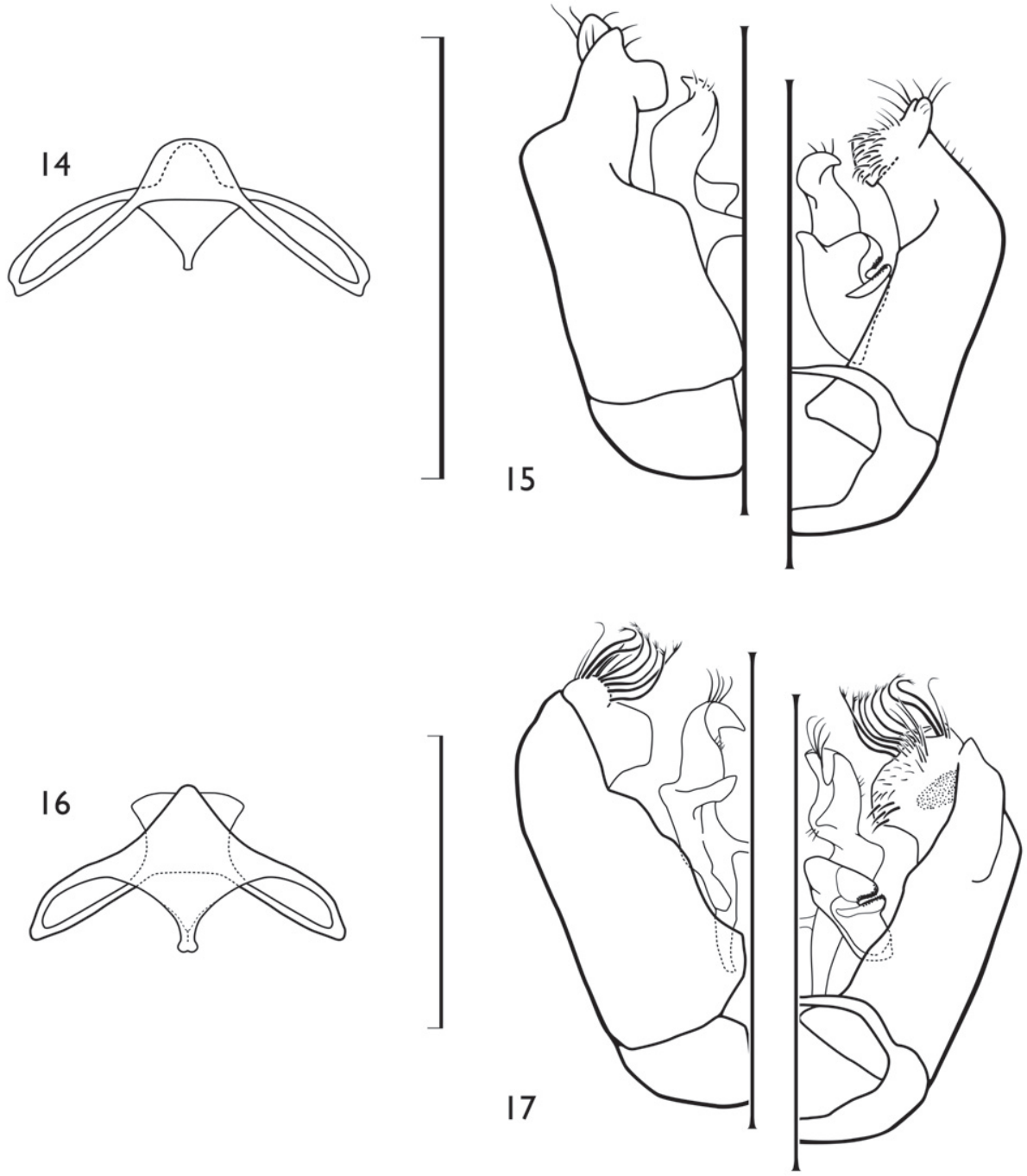

Figures 14-17. Male terminalia for Bolivian Chlerogella species I4 Chlerogella cochabambensis sp. n., hidden and fused sterna VII and VIII I5 C. cochabambensis sp. n., genital capsule (left is dorsal aspect, right is ventral aspect) 16 C. hauseri sp. n., hidden and fused sterna VII and VIII 17 C. hauseri sp. n., genital capsule (left is dorsal aspect, right is ventral aspect). All scale bars $=1 \mathrm{~mm}$.

times length of first flagellomere; ventral surfaces of second through eleventh flagellomeres densely covered in placoid sensilla, placoid fields disrupted by narrow mediolongitudinal line of fine, minute trichoid sensilla in small apical patches on flagellomeres IV-VIII and basal patches on flagellomeres IV-XI, basal and apical patches on flagellomere IV particularly small and basal patch on flagellomere IX longest. Upper portion of pronotum medially depressed, not elongate, medially less than 0.25 times ocellar diameter in length; ventral portion of preëpisternal sulcus not broad, similar to scrobal sulcus and upper por- 
tion of preëpisternal sulcus; intertegular distance $1.43-1.48 \mathrm{~mm}$; mesoscutellum weakly bigibbous. Basal vein distad cu-a by three times vein width; $1 \mathrm{rs}-\mathrm{m}$ distad $1 \mathrm{~m}$-cu by five times vein width; $2 \mathrm{rs}-\mathrm{m}$ distad $2 \mathrm{~m}$-cu by ten times vein width, $2 \mathrm{rs}-\mathrm{m}$ gently curved; first submarginal cell longer than combined lengths of second and third submarginal cells; second submarginal cell slightly narrowed anteriorly, anterior border of second submarginal cell along Rs shorter than that of third submarginal cell; posterior border of third submarginal cell nearly two times longer than anterior border. Distal hamuli arranged 2-1-2. Profemur ventrally swollen; meso- and metafemora somewhat swollen (Fig. 12); inner metatibial spur serrate. Apical margin of SIII entire; apical margin of SIV produced medioapically, with broad concave emargination between setose lobes (Fig. 13), without medio-longitudinal furrow; apical margin of SV with broad, shallow medioapical emargination; apical margin of SVI emarginate; terminalia as depicted in figures 16 and 17.

Clypeus and supraclypeal area imbricate with weak punctures separated by 2-4 times a puncture width; face with small, contiguous punctures, more widely spaced in malar space; punctures of face blending to faintly imbricate integument in ocellocular area and vertex, with small punctures separated by 1-4 times a puncture width; gena faintly imbricate with small punctures separated by $1-2$ times a puncture width; postgena imbricate and impunctate. Pronotum weakly imbricate with minute punctures separated by 1-2.5 times a puncture width; mesoscutum coarsely imbricate with minute punctures separated by a puncture width or less, anteromedially punctures becoming faint to absent; mesoscutellum faintly imbricate with small punctures separated by $1-2$ times a puncture width, separated by less than a puncture width on weak mesoscutellar tubercles; metanotum faintly imbricate with small punctures separated by a puncture width or less. Preëpisternum faintly imbricate with small punctures separated by $1-2$ times a puncture width; mesepisternum faintly imbricate with small punctures separated by $2-5$ times a puncture width, punctures weak; metepisternum faintly imbricate. Propodeum strongly imbricate. Metasoma weakly imbricate.

Mandible and labrum pale yellow; clypeus and malar area alongside clypeus yellow (Figs 10-11), remainder of head shining metallic green, with some golden highlights. Scape and pedicel yellow, although the latter sometimes more brown and the former sometimes with some brown dorsally at apex; first flagellomere brown, remainder of flagellum dark brown. Mesosoma dark metallic green (Fig. 9), with very slight bluish tint on pleura, pronotal lobe yellowish brown (in holotype there is a yellowish spot on the upper third of the metepisternum and the lateral and posterior surfaces of the propodeum are yellowish brown); tegula translucent yellow brown. Wing membranes weakly infumate; veins yellowish brown except $\mathrm{C}$ and $\mathrm{Sc}+\mathrm{R}$ dark brown. Legs yellow except procoxae metallic green as on remainder of mesosoma and brown marks dorsally on meso- and metatibiae and dorsally and ventrally on metafemur (in holotype metacoxa also has metallic green on outer surface and this same area is dark brown without metallic coloration in one of the paratypes). Metasoma dark brown except TI yellow with dark brown apical margin and TII with basolateral yellow spots; SI yellow; SII light brown to brown.

Pubescence golden; typical gender pilosity except postgena with numerous elongate, sinuate setae, such setae with short apical branches; inner surfaces of trochanters, mesofe- 
mur, and metacoxa with elongate, apically-plumose setae, similar setae on inner surfaces of metatrochanter, metafemur, and metatibia except largely simple and somewhat sinuate, those of metatibia particularly elongate and sinuous at apices. Apical margin of SIII with diffuse fringe of moderate-length setae; SIV with small medioapical pads of short dark golden setae bordering medial emargination and lateral areas of more diffuse long, inwardly-curved setae; SV laterally with diffuse areas of long, inwardly-curved setae.

Female: Unknown.

Etymology. The specific epithet is a patronym honoring Dr. Martin Hauser who collected part of the type series, recognized the significance of the bees, and generously made the material available for study.

\section{Chlerogella? buyssoni (Vachal)}

Map 2

Halictus (Rhopalictus) buyssoni Vachal, 1901: 78.

Corynura buyssoni (Vachal); Moure, 1944: 68.

Chlerogella buyssoni (Vachal); Moure and Hurd, 1987: 218; Moure et al., 2007: 794.

Comments. This species was placed without reservation in Chlerogella by Moure and Hurd (1987), who presumably had seen the type specimen. I attempted, without success, to locate the type in the Museum National d'Histoire Naturelle, Paris in 1996 and accordingly could not confirm this generic assignment nor provide a description for the species. Vachal's original description gives the impression of a Chlerogella owing to the elongate head, small size $(6 \mathrm{~mm})$, and pectinate inner metatibial spur with five branches, but he does not provide sufficient detail for a more confident placement. No description of uniquely Chlerogella features such as the dorsal surface of the pronotum (modified in some species) or the propodeum are provided and the few elements given do not match ideally those species before me. Vachal's descriptive notes come closest to C. nasus (Enderlein), but only in superficial details of coloration and given the significantly larger size for the latter I have preferred not to assume that the two are conspecific. Vachal's holotype was collected near Callanga, Perú. Hopefully further collecting in the area will recover new material and the species may be adequately characterized.

\section{Chlerogella arhyncha Engel, sp. n.}

urn:lsid:zoobank.org:act:3D292109-C246-4220-B1AF-4880595E1DC6

Figs 18-23, 39-41, Map 2

Holotype. ㅇ, Perú: Junin, Quebrada Mala Noche, c. 10 km W. San Ramon, 13001500m, 9-12 vi.1993 [9-12 June 1993], M. Cooper (COOP).

Paratypes. Perú: $1 \widehat{O}$, Junin, Quebrada Mala Noche, c. $10 \mathrm{~km}$ W. San Ramon, 1300-1500m, 16.vii.1990 [16 July 1990], M. Cooper (COOP); $2 \widehat{ }{ }^{\lambda}$, Junin, Que- 


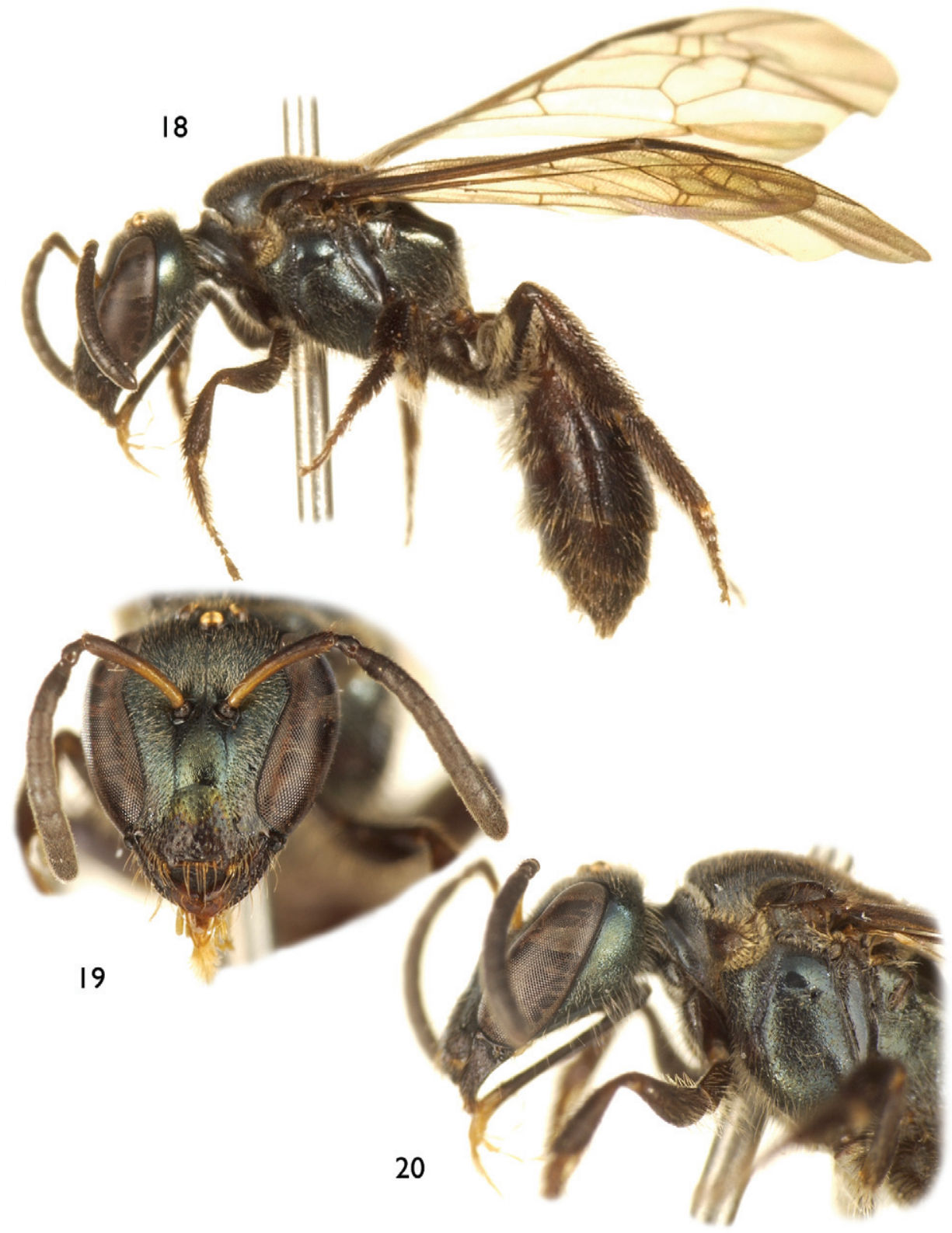

Figures 18-20. Holotype female of Chlerogella arhyncha sp. n. 18 Lateral habitus 19 Facial aspect 20 Lateral aspect of head and anterior mesosoma.

brada Mala Noche, c. 10 km W. San Ramon, 1300-1500m, 9-12 vi.1993 [9-12 June 1993], M. Cooper (COOP).

Diagnosis. Chlerogella arhyncha, as its name suggests, is distinctive for the near absence of a discernible malar space, the compound eye abutting the mandibular base (Figs 19-20, 22-23). 


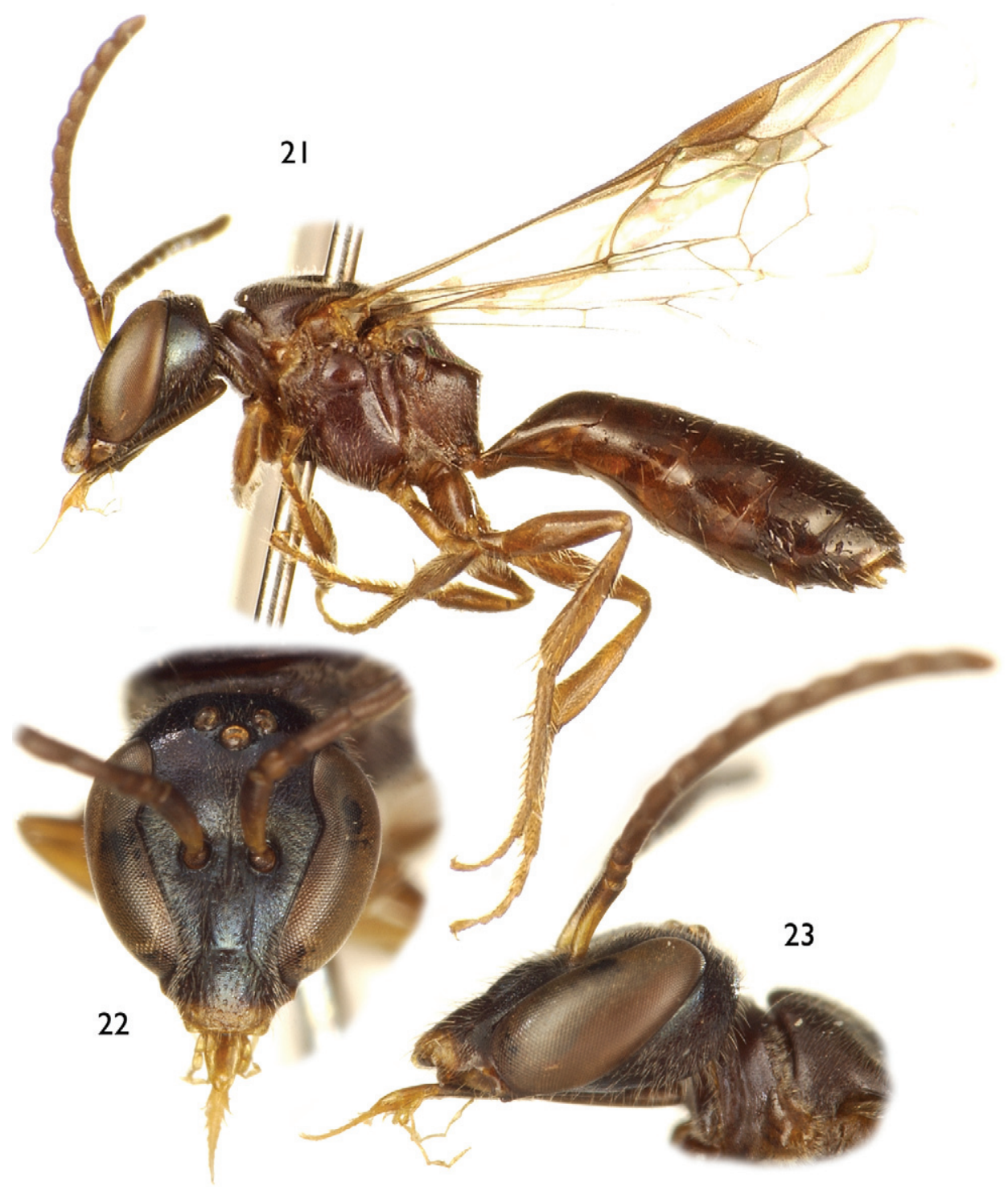

Figures 21-23. Male of Chlerogella arhyncha sp. n. 2 I Lateral habitus 22 Facial aspect $\mathbf{2 3}$ Lateral aspect of head.

Description. Female: Total body length $7.50 \mathrm{~mm}$; forewing length $5.73 \mathrm{~mm}$. Head length $1.90 \mathrm{~mm}$, width $1.67 \mathrm{~mm}$. Clypeus beginning above lower tangent of compound eyes (Fig. 19). Malar space 1.9\% compound eye length (malar length $0.026 \mathrm{~mm}$; compound eye length $1.38 \mathrm{~mm}$ ) (Figs 19-20). Upper interorbital distance $0.89 \mathrm{~mm}$; lower interorbital distance $0.73 \mathrm{~mm}$. Upper portion of pronotum medially depressed, not elongate, medially less than 0.25 times ocellar diameter in length; ventral portion of preëpisternal sulcus not broad, similar to scrobal sulcus and upper portion of preëpisternal 


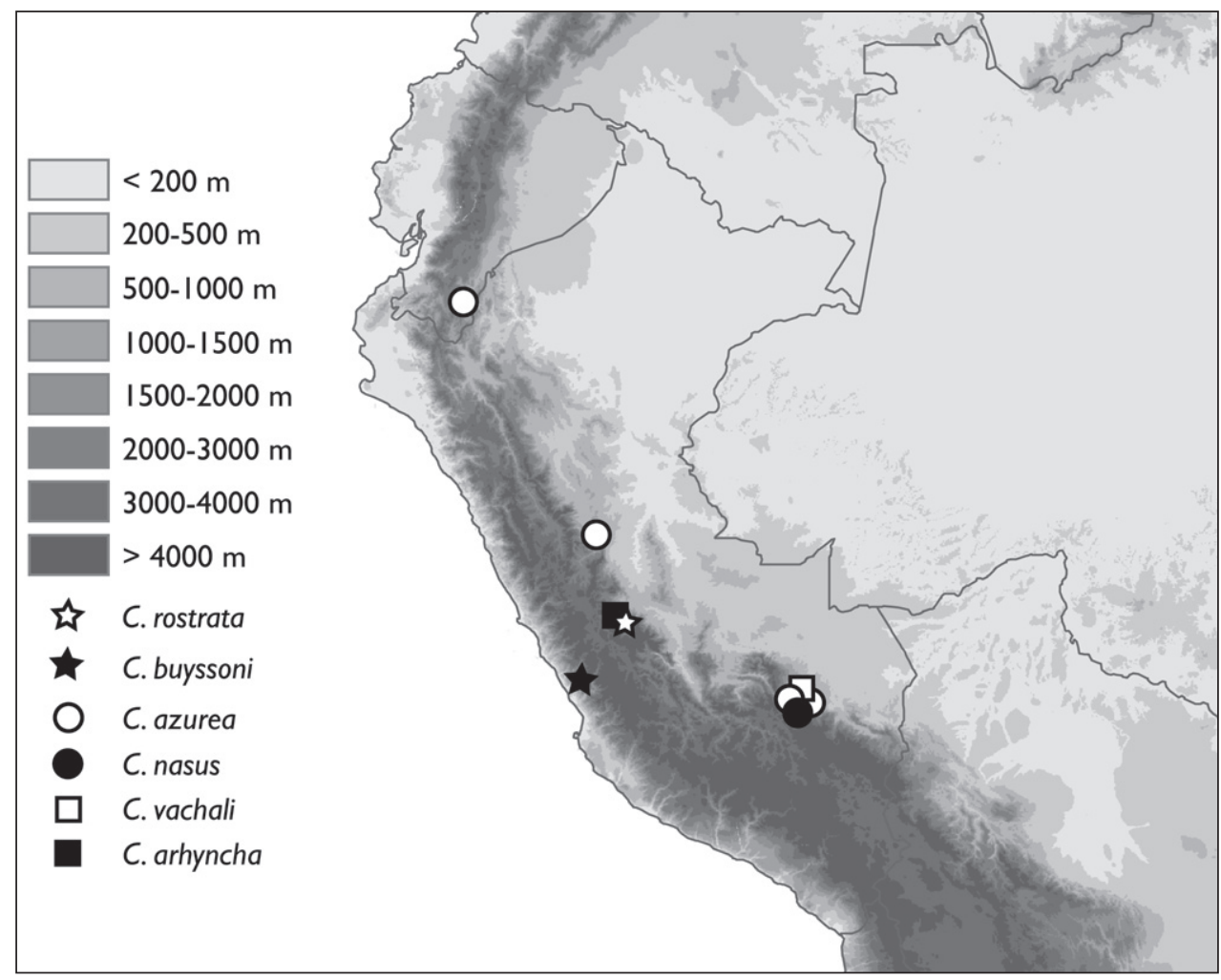

Map 2. Collection localities for Peruvian Chlerogella (note that C. azurea extends into southeastern Ecuador; vide etiam Map 3).

sulcus; intertegular distance $1.22 \mathrm{~mm}$; mesoscutellum weakly convex, not bigibbous. Basal vein distad cu-a by two times vein width; $1 \mathrm{rs}$ - $\mathrm{m}$ distad $1 \mathrm{~m}$-cu by two times vein width; 2 rs-m distad $2 \mathrm{~m}$-cu by five times vein width, 2rs-m relatively straight; first submarginal cell longer than combined lengths of second and third submarginal cells; second submarginal cell slightly narrowed anteriorly, anterior border of second submarginal cell along Rs slightly shorter than that of third submarginal cell; posterior border of third submarginal cell slightly more than two times longer than anterior border. Distal hamuli arranged 2-1-2. Inner metatibial spur with five branches (not including apical portion of rachis).

Clypeus and supraclypeal area imbricate with weak punctures separated by $0.5-2$ times a puncture width; face with small, contiguous punctures, more widely spaced in malar space; punctures of face blending to imbricate integument in ocellocular area and vertex, with punctures separated by a puncture width or less; gena finely imbricate with small punctures separated by 1-2 times a puncture width; postgena imbricate and impunctate. Pronotum imbricate with minute punctures separated by $1-2$ times a puncture width; mesoscutum strongly imbricate with small punctures separated by 1-1.5 times a puncture width on lateral thirds and posteriorly, anteromedially punctures becoming exceedingly faint to absent; mesoscutellum and metanotum imbricate 
with minute scattered punctures. Preëpisternum imbricate, weakly rugulose above; mesepisternum imbricate with small punctures separated by 2-4 times a puncture width, punctures weak; metepisternum faintly imbricate. Propodeum strongly imbricate. Metasoma finely imbricate.

Mandible dark brown except reddish at apex; labrum dark brown; clypeal apex dark brown, remainder of clypeus and head dark metallic bluish green to greenish grey-blue. Antenna dark brown except ventral surface of scape lighter. Mesosoma dark metallic bluish green to greenish grey-blue (Fig. 18); tegula dark brown. Wing membranes lightly infumate; veins dark brown. Legs dark brown. Metasoma dark brown, with apical margins of TIII-VI translucent brown.

Pubescence white to slightly golden except dark fuscous on tibiae, tarsi, and apically on metasoma.

Male: As described for the female except as follows: Total body length 7.20-7.25 $\mathrm{mm}$; forewing length $5.33-5.40 \mathrm{~mm}$. Head length $1.67-1.70 \mathrm{~mm}$, width $1.51-1.53$ $\mathrm{mm}$. Malar space $2.1 \%$ compound eye length (malar length $0.026 \mathrm{~mm}$; compound eye length $1.22-1.23 \mathrm{~mm}$ ) (Figs 22-23). Upper interorbital distance $0.78-0.79 \mathrm{~mm}$; lower interorbital distance $0.52-0.54 \mathrm{~mm}$. First flagellomere about as long as pedicel, about as long as wide; second flagellomere two times length of first flagellomere; ventral surfaces of second through eleventh flagellomeres densely covered in placoid sensilla, placoid fields not disrupted. Intertegular distance 1.07-1.10 mm. Inner metatibial spur minutely ciliate. Apical margin of SIII entire; apical margin of SIV entire, without furrow on disc; apical margin of SV entire; apical margin of SVI emarginate; terminalia as depicted in figures 39 and 41.

Mandible, labrum, and clypeal apex pale yellow, remainder of head dark metallic blue with greenish cast in various places. Antenna brown except ventral surface of scape lighter. Mesosoma reddish brown (faded) with dark metallic blue or greenish blue dorsally and in places on pleura (specimen is clearly very faded) (Fig. 21). Legs brown except tibiae and tarsi lighter. Metasoma dark reddish brown with strong metallic blue highlights on terga.

Pubescence white, with typical gender pilosity. Apical margin of SIII without fringe; SIV with diffuse apicolateral areas of long, white setae; SV laterally with diffuse areas of long, inwardly-curved setae.

Etymology. The specific epithet is a combination of the Greek prefix $a$ (meaning, "without") and the term rhynchos (meaning, "snout").

\section{Chlerogella vachali Engel, sp. n.}

urn:lsid:zoobank.org:act:4534952C-2A8C-4B33-AA58-2A134BF86A19

Figs 24-26, Map 2

Holotype. + , Perú: Dept. Madre de Dios, Amazonas Lodge, N. Atalaya, 1252.2'S, $71^{\circ} 22.6^{\prime} \mathrm{W}, 480 \mathrm{~m}, 10-13-\mathrm{XI}-2007$ [10-13 November 2007], D. Brzoska, ex: flight intercept trap (MUSM). 


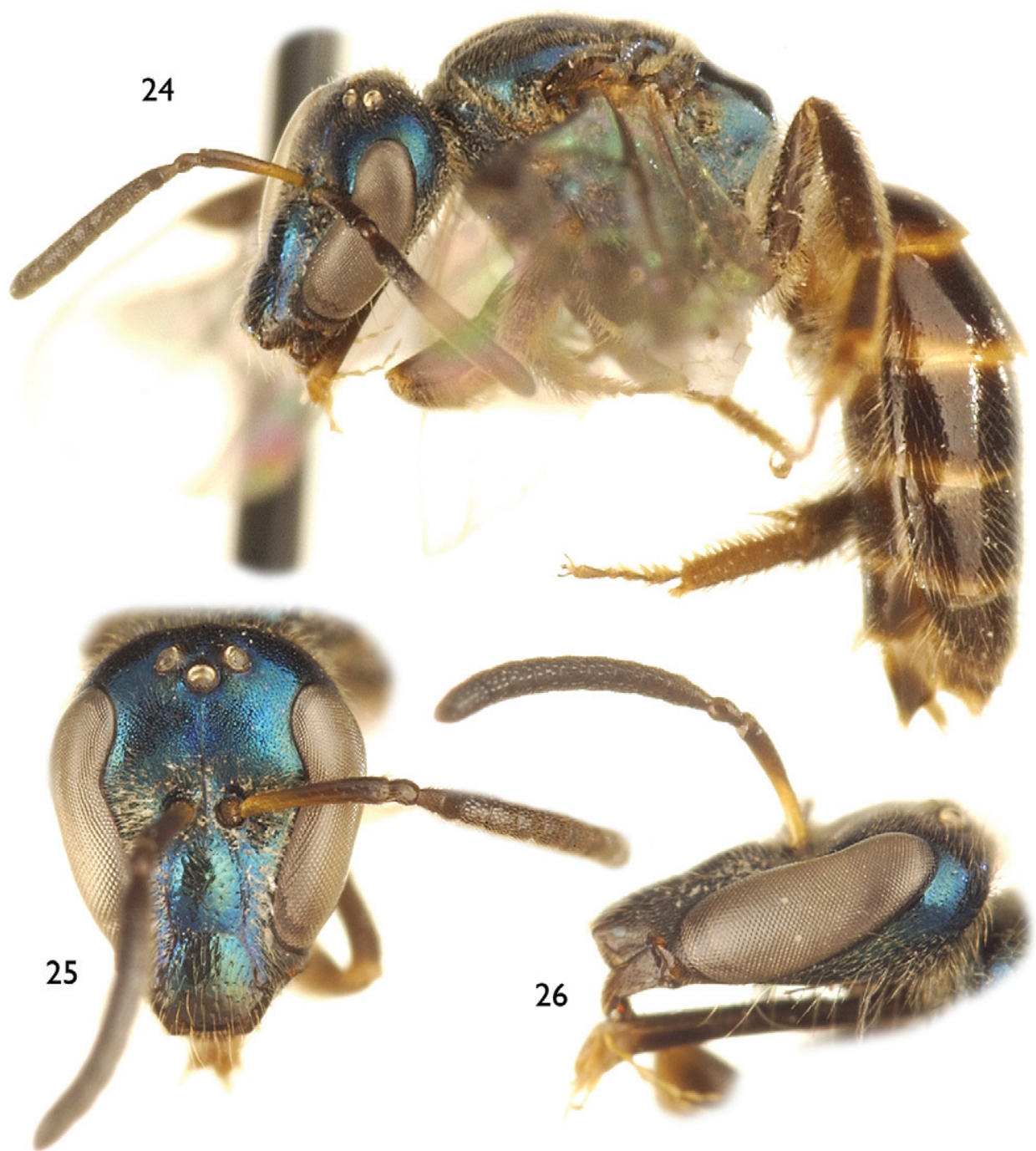

Figures 24-26. Holotype female of Chlerogella vachali sp. n. 24 Lateral habitus $\mathbf{2 5}$ Facial aspect 26 Lateral aspect of head.

Diagnosis. Among short-headed species of Chlerogella, C. vachali can be recognized by the combination of the generally dark brown metasoma with an amber spot centrally on the first metasomal tergum, the brilliant metallic blue coloration of the head and mesosoma (Figs 24-26), the more widely spaced punctures of the mesoscutum, and its small body size.

Description. Female: Total body length $6.38 \mathrm{~mm}$; forewing length $4.40 \mathrm{~mm}$. Head length $1.64 \mathrm{~mm}$, width $1.30 \mathrm{~mm}$. Clypeus beginning above lower tangent of compound eyes. Malar space $7.2 \%$ compound eye length (malar length $0.078 \mathrm{~mm}$; 
compound eye length $1.09 \mathrm{~mm}$ ) (Figs 25-26). Upper interorbital distance $0.73 \mathrm{~mm}$; lower interorbital distance $0.52 \mathrm{~mm}$. Upper portion of pronotum medially depressed, not elongate, medially less than 0.25 times ocellar diameter in length; ventral portion of preëpisternal sulcus not broad, similar to scrobal sulcus and upper portion of preëpisternal sulcus; intertegular distance $0.99 \mathrm{~mm}$; mesoscutellum weakly convex, not bigibbous. Basal vein distad cu-a by 3.5 times vein width; $1 \mathrm{rs}-\mathrm{m}$ distad $1 \mathrm{~m}$-cu by two times vein width; $2 \mathrm{rs}-\mathrm{m}$ distad $2 \mathrm{~m}$-cu by five times vein width, 2 rs-m relatively straight; first submarginal cell longer than combined lengths of second and third submarginal cells; second submarginal cell narrowed anteriorly, anterior border of second submarginal cell along Rs about one-half as long as that of third submarginal cell; posterior border of third submarginal cell about two times longer than anterior border. Distal hamuli arranged 2-1-2. Inner metatibial spur with four branches (not including apical portion of rachis).

Clypeus and supraclypeal area finely imbricate with weak punctures separated by a puncture width or less; face with small, contiguous punctures, more widely spaced in malar space; punctures of face blending to smooth integument in ocellocular area and vertex, with punctures separated by $0.5-2$ times a puncture width; gena smooth with small punctures separated by 1-2 times a puncture width; postgena imbricate and impunctate. Pronotum faintly imbricate with minute punctures separated by 1-3 times a puncture width; mesoscutum smooth with small punctures separated by 1-2 times a puncture width, anteromedially punctures becoming faint to absent and finely imbricate; mesoscutellum smooth with minute punctures separated by 1.5-3.5 times a puncture width; metanotum smooth with scattered minute punctures. Preëpisternum smooth with small punctures separated by 1-3 times a puncture width; mesepisternum smooth with small punctures separated by 2-6 times a puncture width, punctures weak; metepisternum faintly imbricate. Propodeum strongly imbricate. Metasoma finely imbricate.

Mandible dark brown except reddish at apex; labrum dark brown; clypeal apex dark brown, remainder of clypeus and head brilliant metallic azurite blue. Antenna dark brown except basal half of scape yellow brown. Mesosoma brilliant metallic azurite blue except pronotal lobe brown (Fig. 24); tegula dark brown. Wing membranes hyaline; veins dark brown. Legs dark brown except procoxa brilliant metallic azurite blue. Metasoma dark brown, with apical margins of terga translucent light brown and medial anterior-facing surface of TI amber brown.

Pubescence white to slightly golden except intermingled with fuscous setae at apex of metasoma.

Male: Unknown.

Etymology. The specific epithet is a patronym honoring Joseph Vachal (18381911), an early pioneer in the systematics of Halictidae, particularly the South American fauna, and who likely described the first species of Chlerogella from an individual in Perú (C. buyssoni, vide supra). 


\section{Chlerogella nasus (Enderlein)}

Figs 27-29, Map 2

Halictus nasus Enderlein, 1903: 38.

Chlerogella nasus (Enderlein); Moure and Hurd, 1987: 218; Moure et al., 2007: 795.

Holotype. + , Perú: Departement Cuzco, Cosnipata-Ebene, 1000 m, 3 December 1900, S.V. Garlepp (ZMHB).

Additional material. Perú: 19 , Dept. Cusco, Cock of the Rock Lodge, NE Paucartambo, 1303.3'S, 71³2.7'W, 1120 m, 4-9-XI-2007 [4-9 November 2007], D. Brzoska, ex: flight intercept trap (SEMC).

Diagnosis. Chlerogella nasus is distinctive for the combination of its elongate malar space and dark brown coloration, with weak metallic highlights (Figs 27-29).

Description. Female: Total body length $9.44-9.64 \mathrm{~mm}$; forewing length 6.80 $7.04 \mathrm{~mm}$. Head length $2.58-2.60 \mathrm{~mm}$, width $1.76-1.78 \mathrm{~mm}$. Clypeus beginning just below lower tangent of compound eyes. Malar space 35.6-37.2\% compound eye length (malar length $0.52-0.55 \mathrm{~mm}$; compound eye length $1.46-1.48 \mathrm{~mm}$ ) (Figs. 28-29). Upper interorbital distance $0.88-0.89 \mathrm{~mm}$; lower interorbital distance 0.63-0.64 $\mathrm{mm}$. Upper portion of pronotum medially depressed, not elongate, medially less than 0.25 times ocellar diameter in length; ventral portion of preëpisternal sulcus not broad, similar to scrobal sulcus and upper portion of preëpisternal sulcus; intertegular distance 1.35-1.40 mm; mesoscutellum weakly convex, not bigibbous. Basal vein distad cu-a by two times vein width; $1 \mathrm{rs}-\mathrm{m}$ distad $1 \mathrm{~m}$-cu by two times vein width; 2 rs- $\mathrm{m}$ distad $2 \mathrm{~m}$-cu by five times vein width, $2 \mathrm{rs}$ - $\mathrm{m}$ gently arched; first submarginal cell longer than combined lengths of second and third submarginal cells; second submarginal cell slightly narrowed anteriorly, anterior border of second submarginal cell along Rs slightly shorter than that of third submarginal cell; posterior border of third submarginal cell slightly more than 1.5 times longer than anterior border. Distal hamuli arranged 2-1-2. Inner metatibial spur with four branches (not including apical portion of rachis).

Clypeus and supraclypeal area imbricate with weak punctures separated by $0.5-2$ times a puncture width; face with small, contiguous punctures, more widely spaced in malar space; punctures of face blending to imbricate integument in ocellocular area and vertex, with punctures separated by a puncture width or less; gena imbricate with small punctures separated by a puncture width; postgena imbricate and impunctate. Pronotum imbricate with scattered minute punctures; mesoscutum with small contiguous punctures, anteromedially punctures becoming weaker and integument distinctly imbricate; mesoscutellum and metanotum with small contiguous punctures. Preëpisternum strongly imbricate with coarse punctures separated by a puncture width or less; mesepisternum strongly imbricate with weak punctures separated by $2-5$ times a puncture width; metepisternum finely imbricate. Propodeum strongly imbricate. Metasoma finely imbricate. 


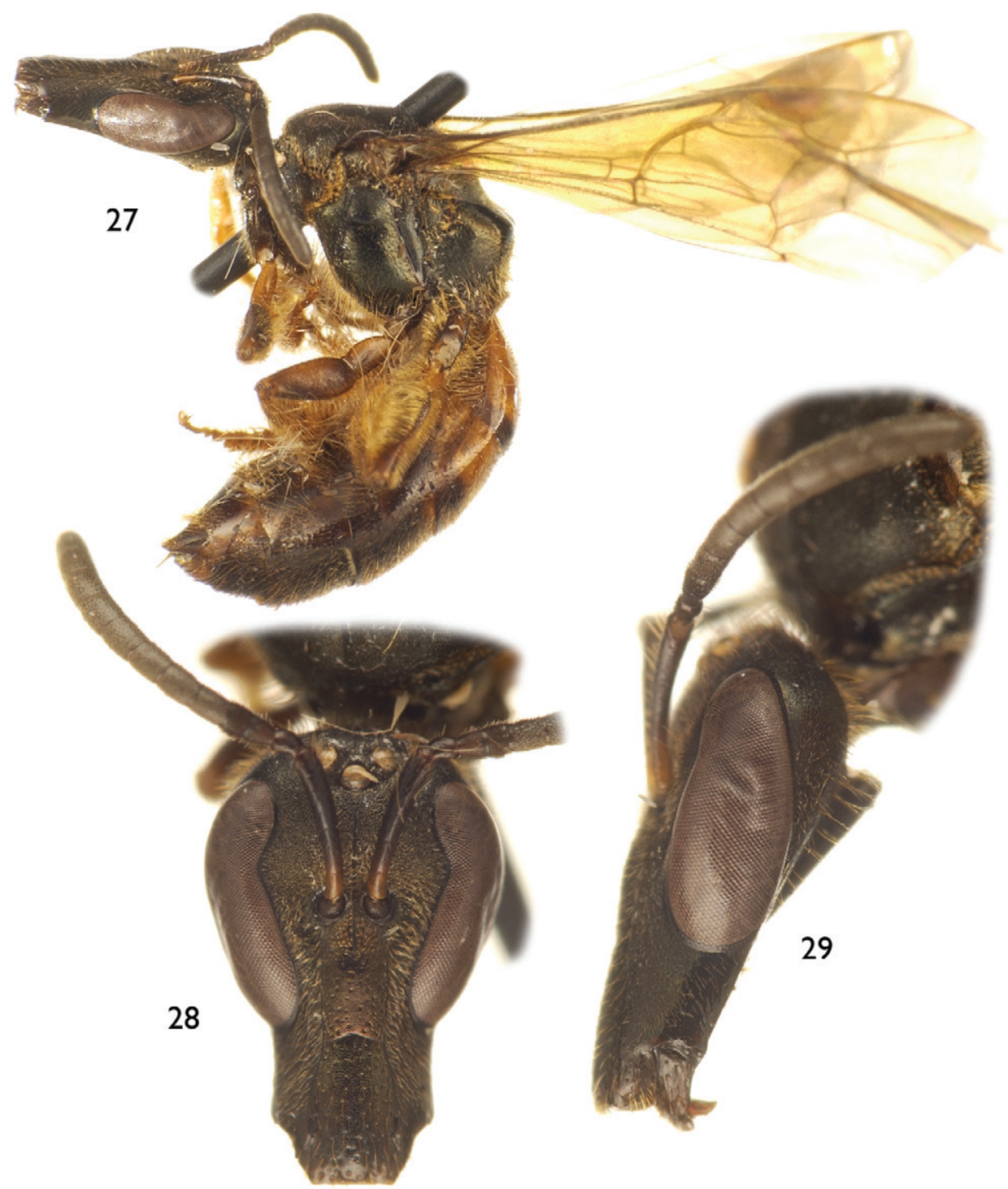

Figures 27-29. Female of Chlerogella nasus (Enderlein). 27 Lateral habitus 28 Facial aspect 29 Lateral aspect of head.

Mandible dark brown except reddish at apex; labrum dark brown; clypeal apex dark brown to black, remainder of clypeus and head dark brown to nearly black with weak metallic copper-green highlights. Antenna dark brown except base of scape brown. Mesosoma dark brown to nearly black with weak metallic copper-green highlights (Fig. 27); tegula dark brown. Wing membranes lightly infumate; veins dark brown. Legs amber brown except procoxa dark brown with weak metallic copper-green 
highlights. Metasoma dark brown except amber brown on TI, TII except apical margin dark brown, and basal third of TIII (apical two-thirds dark brown).

Pubescence golden except intermingled with fuscous setae apically on metasoma.

Male: Unknown.

\section{Chlerogella rostrata Engel, sp. n.}

urn:lsid:zoobank.org:act:8B314451-279E-4B7F-A803-21D0BA5F050F

Figs 1, 30-32, Map 2

Holotype. + , Perú: Junin, Quebrada, Mala Noche, c. 10 km West San Ramon, 1300-1500 m, 9-12.vi.1993, M. Cooper (COOP).

Paratypes. Perú: 2 + 9 , Junin, Quebrada, Mala Noche, c. $10 \mathrm{~km}$ West San Ramon, 1300-1500 m, 9-12.vi.1993, M. Cooper (COOP).

Diagnosis. Chlerogella rostrata belongs to a complex of very similar metallic blue species with elongate malar spaces. It is most similar to C. materdonnae but differs by the more dull, non-shining caerulean blue color of the integument (Figs 30-31; cf. Figs 55-56) and the more densely spaced punctures ventrally on the mesepisternum.

Description. Female: Total body length $9.53-9.65 \mathrm{~mm}$; forewing length 7.0-7.15 $\mathrm{mm}$. Head length $2.73-2.75 \mathrm{~mm}$, width $1.88-1.91 \mathrm{~mm}$. Clypeus beginning below lower tangent of compound eyes. Malar space 38.5-38.6\% compound eye length (malar length $0.60-0.61 \mathrm{~mm}$; compound eye length $1.56-1.58 \mathrm{~mm}$ ) (Figs 31-32). Upper interorbital distance $0.88-0.89 \mathrm{~mm}$; lower interorbital distance $0.68-0.69 \mathrm{~mm}$. Upper portion of pronotum medially depressed, not elongate, medially less than 0.25 times ocellar diameter in length; ventral portion of preëpisternal sulcus not broad, similar to scrobal sulcus and upper portion of preëpisternal sulcus; intertegular distance 1.51-1.52 mm; mesoscutellum weakly convex, not bigibbous. Basal vein distad cu-a by two times vein width; $1 \mathrm{rs}$-m distad $1 \mathrm{~m}$-cu by three times vein width; $2 \mathrm{rs}-\mathrm{m}$ distad $2 \mathrm{~m}$-cu by nine times vein width, $2 \mathrm{rs}-\mathrm{m}$ relatively straight; first submarginal cell longer than combined lengths of second and third submarginal cells; second submarginal cell slightly narrowed anteriorly, anterior border of second submarginal cell along Rs about as along as that of third submarginal cell; posterior border of third submarginal cell slightly more than two times longer than anterior border. Distal hamuli arranged 2-12. Inner metatibial spur with four branches (not including apical portion of rachis).

Clypeus and supraclypeal area imbricate with weak punctures separated by $0.5-1.5$ times a puncture width; face with small, contiguous punctures, more widely spaced in malar space; punctures of face blending to imbricate integument in ocellocular area and vertex, with punctures separated by a puncture width or less; gena finely imbricate with small punctures separated by $0.5-2$ times a puncture width; postgena imbricate and impunctate. Pronotum imbricate with minute punctures separated by $1-3$ times a puncture width; mesoscutum imbricate with punctures separated by a puncture width or less on lateral thirds and posteriorly, anteromedially punctures becoming exceedingly faint to absent; mesoscutellum finely imbricate with small punctures separated by a puncture 


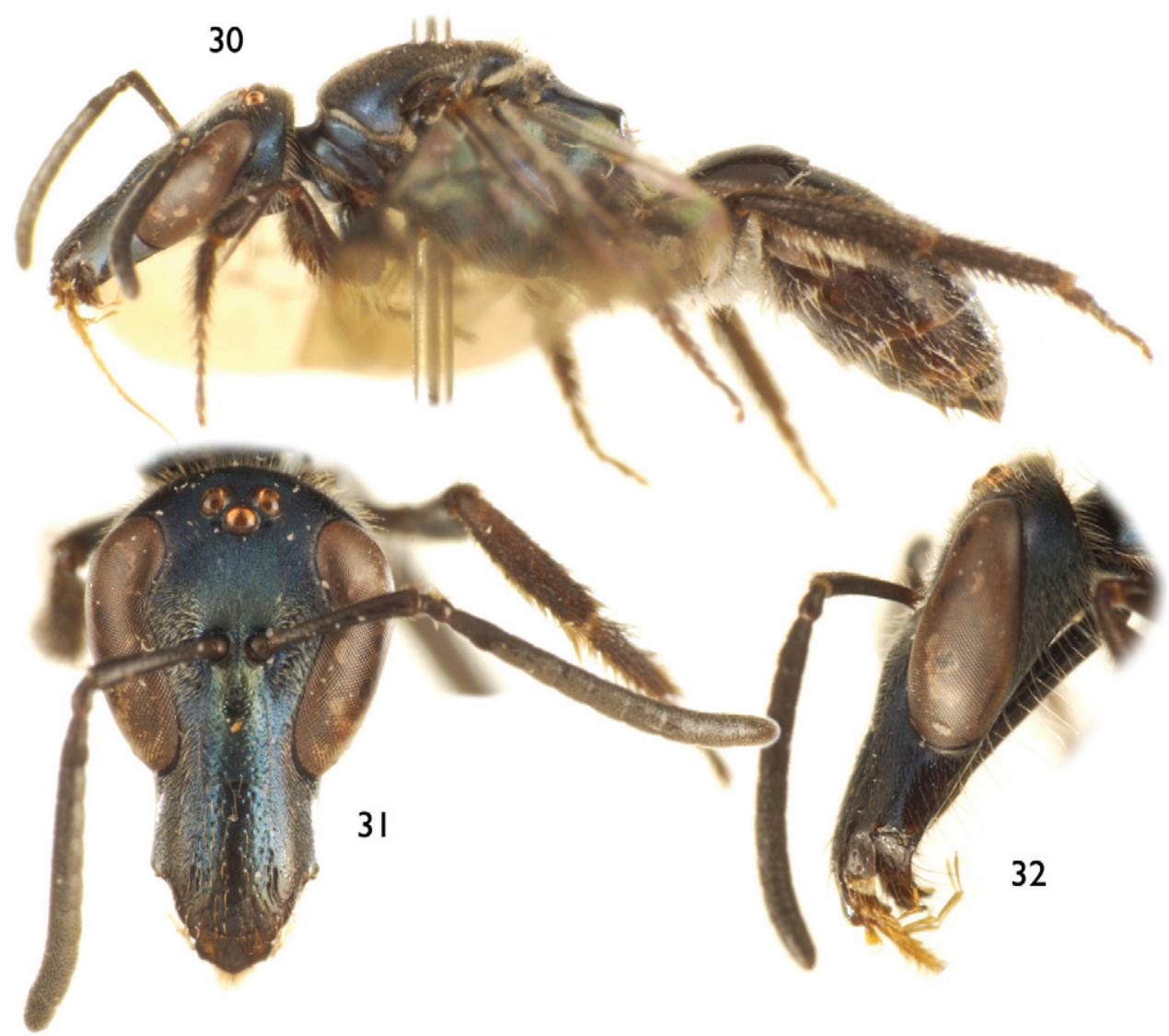

Figures 30-32. Holotype female of Chlerogella rostrata sp. n. 30 Lateral habitus 31 Facial aspect 32 Lateral aspect of head.

width or less; metanotum imbricate with minute punctures separated by a puncture width or less. Preëpisternum finely imbricate with small punctures separated by 1-3 times a puncture width; mesepisternum finely imbricate with punctures widely spaced in upper half, separated by $2-5$ times a puncture width, blending to noticeably more dense posteriorly and ventrally, separated by $0.5-2$ times a puncture width; metepisternum faintly imbricate. Propodeum strongly imbricate. Metasoma finely imbricate.

Mandible dark brown except reddish at apex; labrum dark brown; clypeal apex black, remainder of clypeus and head dark, dull metallic caerulean blue (Fig. 31). Antenna dark brown. Mesosoma dark, dull metallic caerulean blue (Fig. 30); tegula dark brown. Wing membranes lightly infumate; veins dark brown. Legs dark brown. Metasoma dark brown.

Pubescence white except intermingled with dark fuscous setae on metatibia and with dark fuscous setae predominant on tarsi, apicalmost metasomal segments, and pro- and mesotibiae. 
Male: Unknown.

Etymology. The specific epithet is taken from the Latin term rostratus, meaning "beaked".

\section{Chlerogella azurea (Enderlein), comb. n.}

Figs 33-38, 42-44, Maps 2, 3

Halictus azureus Enderlein, 1903: 40.

Caenohalictus azureus (Enderlein); Moure and Hurd, 1987: 177; Moure et al., 2007: 830.

Holotype. ${ }^{\top}$; Perú: Departement Cuzco, Cosnipata-Ebene, 1000 m, 5 January 1901, S.V. Garlepp (ZMHB).

Additional material. Perú: 19 , Huanuco Dept., P.N. Tingo Maria vic cueva d., Lechuzas, 15 January 1983, A. Newton \& M. Thayer (SEMC); 1 9 , Huanuco Dept., Tingo Maria, 30-1-1984 [30 January 1984], L. Huggert (PMAE); 19, Tingo Maria, 20-27.i.1968 [20-27 January 1968], A. Garcia \& C. Porter (SEMC); 1ㅇ,

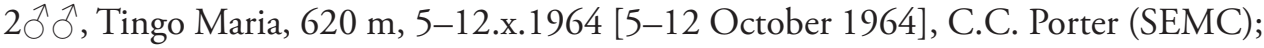
1 , , Dept. Cusco, Cock of the Rock Lodge, NE Paucartambo, $13^{\circ} 03.3^{\prime} \mathrm{S}, 71^{\circ} 32.7^{\prime} \mathrm{W}$, 1120 m, 4-9-XI-2007 [4-9 November 2007], D. Brzoska, ex: flight intercept trap (SEMC). Ecuador: 1잉, Morona-Santiago, Cord. de Cutucu, 6km E Macas, $1000 \mathrm{~m}$, 12.viii.1990 [12 August 1990], M. Cooper (COOP); 1 §, Zamora [Province], Zamora 1200 m, xi-23-1970, L. Pena (AMNH).

Diagnosis. Chlerogella azurea belongs to a complex of exceptionally similar metallic blue species with elongate heads. Among those species in this complex with bright azurite blue coloration, C. azurea is most similar to C. agaylei in which females are virtually indistinguishable, although the former tends to be slightly more lighter blue in some individuals (e.g., Fig. 33, although some approximate that of C. agaylei) and the scape tends to have some lighter coloration basally. The unmodified SIV in males makes them easy to distinguish from C. agaylei.

Description. Female: Total body length $7.95-8.23 \mathrm{~mm}$; forewing length $5.40-5.61$ $\mathrm{mm}$. Head length $2.39-2.50 \mathrm{~mm}$, width $1.40-1.46 \mathrm{~mm}$. Clypeus beginning well below lower tangent of compound eyes. Malar space 41.4-41.8\% compound eye length (malar length 0.55-0.56 mm; compound eye length 1.33-1.34 mm) (Figs. 34-35). Upper interorbital distance $0.73-0.75 \mathrm{~mm}$; lower interorbital distance $0.47-0.49 \mathrm{~mm}$. Upper portion of pronotum medially depressed, not elongate, medially less than 0.25 times ocellar diameter in length; ventral portion of preëpisternal sulcus not broad, similar to scrobal sulcus and upper portion of preëpisternal sulcus; intertegular distance $1.25-1.30 \mathrm{~mm}$; mesoscutellum weakly convex, not bigibbous. Basal vein distad cu-a by two times vein width; $1 \mathrm{rs}-\mathrm{m}$ distad $1 \mathrm{~m}$-cu by three times vein width; $2 \mathrm{rs}-\mathrm{m}$ distad $2 \mathrm{~m}$-cu by seven times vein width, 2 rs-m relatively straight; first submarginal cell longer than combined lengths of second and third submarginal cells; second submarginal cell 


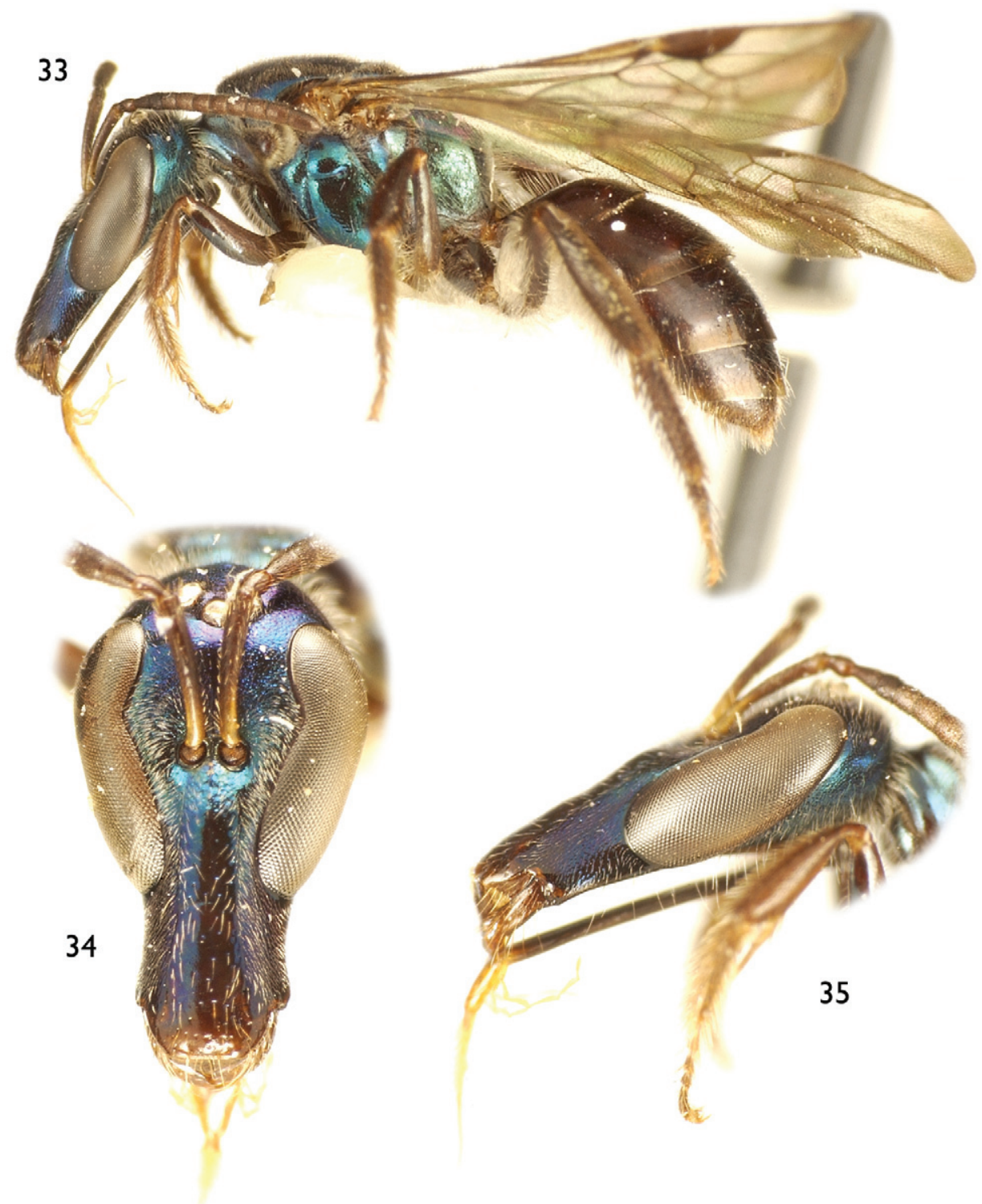

Figures 33-35. Female of Chlerogella azurea (Enderlein), comb. n. 33 Lateral habitus 34 Facial aspect 35 Lateral aspect of head.

slightly narrowed anteriorly, anterior border of second submarginal cell along Rs about as along as that of third submarginal cell; posterior border of third submarginal cell slightly more than two times longer than anterior border. Distal hamuli arranged 2-12. Inner metatibial spur with six branches (not including apical portion of rachis).

Clypeus and supraclypeal area finely imbricate with weak punctures separated by 0.5-2 times a puncture width; face with small, contiguous punctures, more widely 


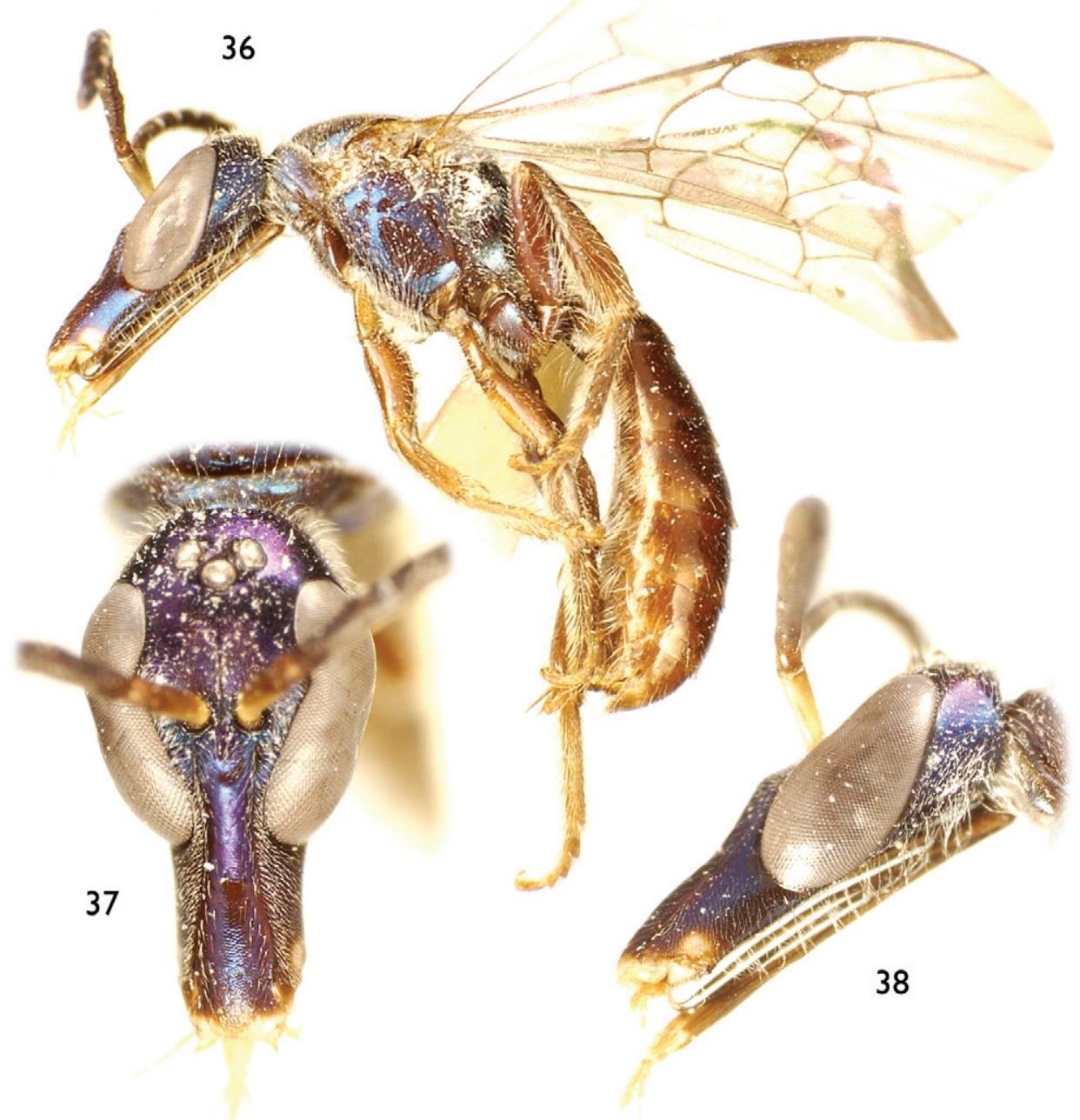

Figures 36-38. Male of Chlerogella azurea (Enderlein), comb. n. 36 Lateral habitus 37 Facial aspect 38 Lateral aspect of head.

spaced in malar space; punctures of face blending to imbricate integument in ocellocular area and vertex, with punctures separated by 1-2 times a puncture width; gena finely imbricate with small punctures separated by $0.5-2$ times a puncture width; postgena imbricate and impunctate. Pronotum imbricate with minute punctures separated by 1-3 times a puncture width; mesoscutum imbricate with punctures separated by a puncture width or less on lateral thirds and posteriorly, anteromedially punctures becoming exceedingly faint to absent; mesoscutellum finely imbricate with small punctures separated by a puncture width or less; metanotum imbricate with minute punctures separated by 
39

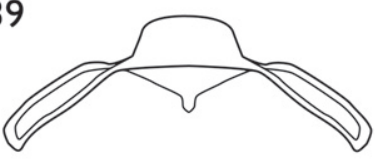

40

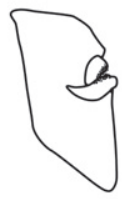

42

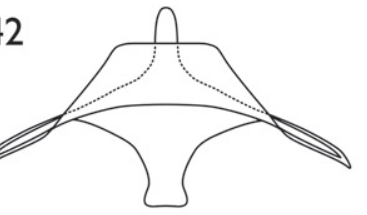

43

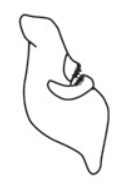

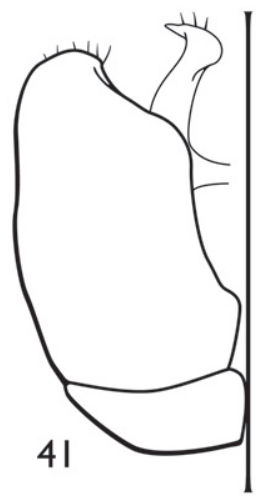
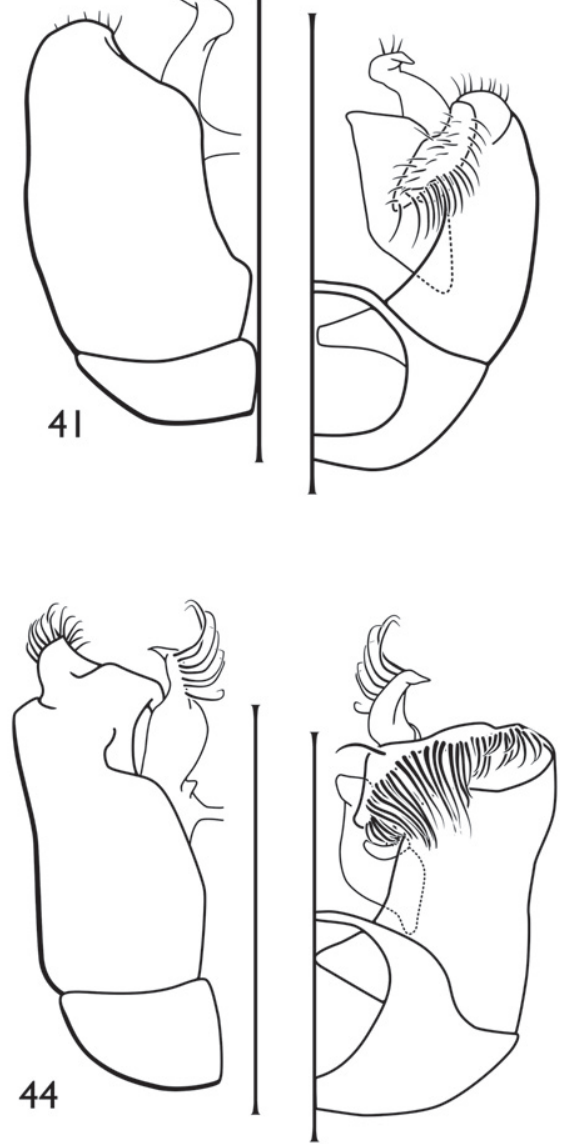

Figures 39-44. Male terminalia for Peruvian Chlerogella species [note: C. azurea (Enderlein), comb. n., also has been recorded from southeastern Ecuador, vide Map 3]. 39 Chlerogella arhyncha sp. n., hidden and fused sterna VII and VIII 40 Detail of volsella for C. arhyncha sp. n. 4I C. arhyncha sp. n., genital capsule (left is dorsal aspect, right is ventral aspect) $\mathbf{4 2}$ C. azurea, hidden and fused sterna VII and VIII $\mathbf{4 3}$ Detail of volsella for C. azurea 44 C. azurea, genital capsule (left is dorsal aspect, right is ventral aspect). All scale bars $=1 \mathrm{~mm}$.

a puncture width or less. Preëpisternum finely imbricate with small punctures separated by $1-3$ times a puncture width; mesepisternum smooth and shining to faintly imbricate with weak punctures separated by $2-5$ times a puncture width; metepisternum faintly imbricate. Propodeum strongly imbricate. Metasoma finely imbricate.

Mandible dark brown except reddish at apex; labrum dark brown; clypeal apex black, remainder of clypeus and head brilliant metallic azurite blue, with purple highlights. Antenna dark brown. Mesosoma brilliant metallic azurite blue, with purple highlights (Fig. 33); tegula dark brown. Wing membranes lightly infumate; veins dark brown. Legs dark brown. Metasoma dark brown. 


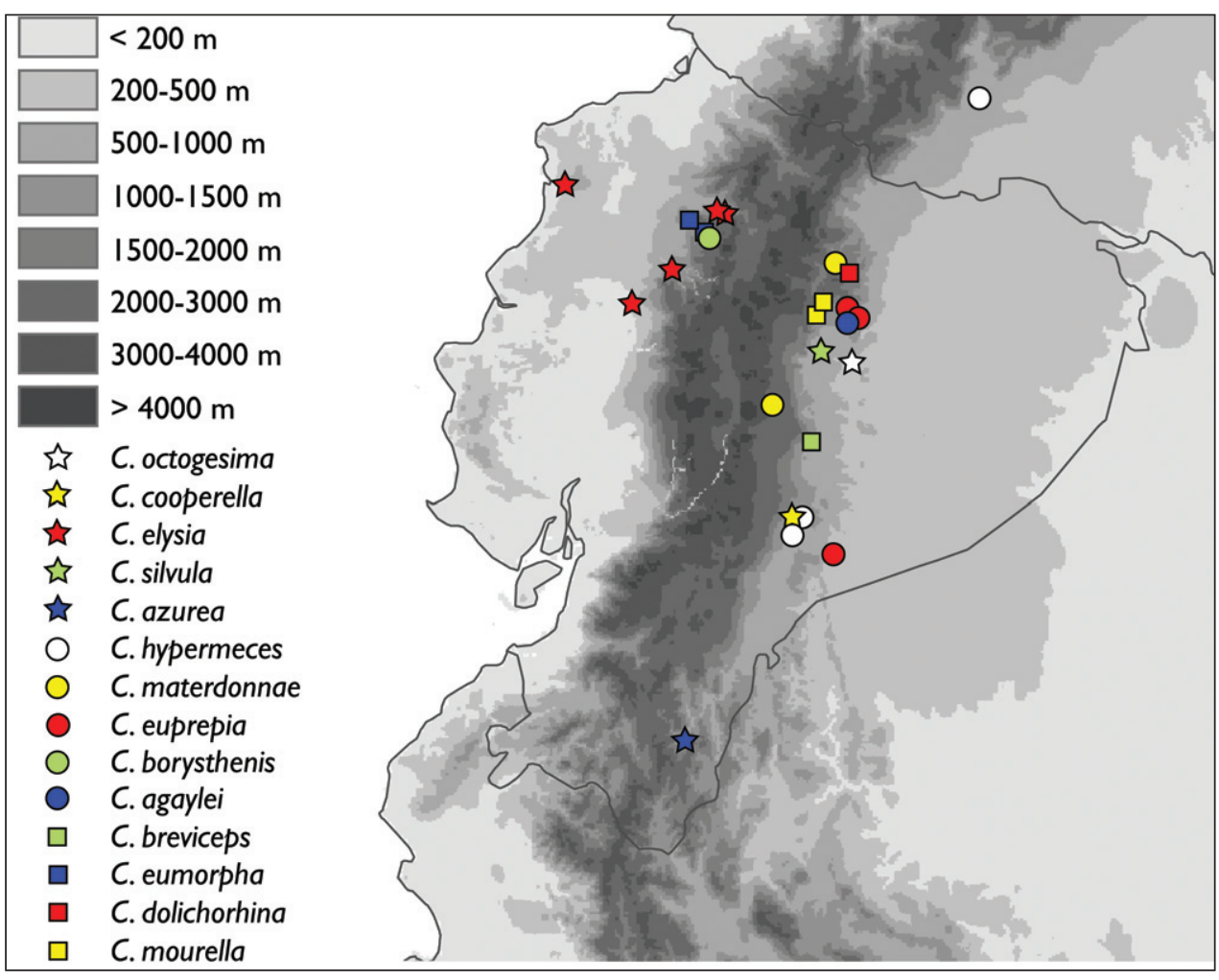

Map 3. Collection localities for Ecuadorian Chlerogella (note that $C$. azurea has been captured principally in Perú and C. hypermeces in Colombia; vide etiam Maps 2 \& 4).

Pubescence white except intermingled with dark fuscous setae on metatibia and with dark fuscous setae predominant on tarsi, apicalmost metasomal segments, and pro- and mesotibiae.

Male: As described for the female except as follows: Total body length 8.02-8.10 $\mathrm{mm}$; forewing length $5.33-5.41 \mathrm{~mm}$. Head length $2.42-2.45 \mathrm{~mm}$, width $1.33-1.36$ $\mathrm{mm}$. Clypeus beginning well below lower tangent of compound eyes. Malar space $47.6-48 \%$ compound eye length (malar length $0.60 \mathrm{~mm}$; compound eye length $1.25-1.26 \mathrm{~mm}$ ) (Figs 37-38). Upper interorbital distance 0.65-0.66 mm; lower interorbital distance $0.34-0.35 \mathrm{~mm}$. First flagellomere about as long as pedicel, about as long as wide; second flagellomere two times length of first flagellomere; ventral surfaces of second through eleventh flagellomeres densely covered in placoid sensilla, placoid fields not disrupted. Intertegular distance 1.07-1.10 mm; mesoscutellum not bigibbous. Inner metatibial spur serrate. Apical margin of SIII entire; apical margin of SIV entire or faintly concave, without furrow in apical half of disc; apical margin of SV entire; apical margin of SVI emarginate; terminalia as depicted in figures 42-44.

Mandible, labrum, and clypeal apex white, often with spot of white in malar space near mandibular base; scape yellow ventrally. Purple coloration stronger in some speci- 
mens (resulting from fading of darker underlying integument to a reddish brown shade which with the azurite blue results in a metallic purple coloration: e.g., Fig. 36).

Typical gender pilosity except postgena with numerous elongate, sinuate setae, such setae with short apical branches; inner surfaces of trochanters, mesofemur, and metacoxa with elongate, apically-plumose setae, similar setae on inner surfaces of metatrochanter, metafemur, and metatibia except largely simple and somewhat sinuate, those of metatibia particularly elongate, longer than metatibial width. Apical margin of SIII with diffuse fringe of moderate-length white setae; SIV with diffuse medioapical areas of long setae; SV similar to SIV although setae even more diffuse.

Comment. The elongate head of the holotype and sparse description of Enderlein (1903) is perhaps what misled Moure and Hurd (1987) to transfer this species to Caenohalictus in the Caenohalictini. During a study of Caenohalictus by B.W.T. Coelho she borrowed the holotype and discovered that the specimen belongs to the Augochlorini, not the Caenohalictini, and was indeed a species of Chlerogella. I am grateful to her for bringing this to my attention so that I was able to examine Enderlein's specimen, transfer it to the genus Chlerogella, and properly associate it among its relatives.

\section{Chlerogella dolichorhina Engel, sp. n.}

urn:lsid:zoobank.org:act:4403F04E-199C-4732-BBDD-3C2898F214B1

Figs 45-47, Map 3

Holotype. + , Ecuador: Napo, Chaco, 11 March 1983, Masner and Sharkey (SEMC).

Paratype. Ecuador: 1 9 , Napo, Chaco, 11.iii.1983 [11 March 1983], Masner \& Sharkey (PMAE).

Diagnosis. The female of $C$. dolichorbina is superficially most similar to $C$. agaylei but can be distinguished by the strongly and coarsely imbricate mesepisternum and the more dull and non-shining blue coloration, with only faint purple highlights (Figs. 45-47).

Description. Female: Total body length $8.85 \mathrm{~mm}$; forewing length $6.53 \mathrm{~mm}$. Head length $2.71 \mathrm{~mm}$, width $1.69 \mathrm{~mm}$. Clypeus beginning below lower tangent of compound eyes. Malar space 45.9\% compound eye length (malar length $0.68 \mathrm{~mm}$; compound eye length $1.48 \mathrm{~mm}$ ) (Figs 46-47). Upper interorbital distance $0.83 \mathrm{~mm}$; lower interorbital distance $0.57 \mathrm{~mm}$. Upper portion of pronotum medially depressed, not elongate, medially less than 0.25 times ocellar diameter in length; ventral portion of preëpisternal sulcus not broad, similar to scrobal sulcus and upper portion of preëpisternal sulcus; intertegular distance $1.3 \mathrm{~mm}$; mesoscutellum weakly convex, not bigibbous. Basal vein distad cu-a by two times vein width; $1 \mathrm{rs}-\mathrm{m}$ distad $1 \mathrm{~m}$-cu by three times vein width; $2 \mathrm{rs}-\mathrm{m}$ distad $2 \mathrm{~m}$-cu by nine times vein width, $2 \mathrm{rs}-\mathrm{m}$ relatively straight; first submarginal cell longer than combined lengths of second and third submarginal cells; second submarginal cell slightly narrowed anteriorly, anterior border of second submarginal cell along Rs about as along as that of third submarginal cell; posterior border of third submarginal cell slightly more than two times longer than an- 


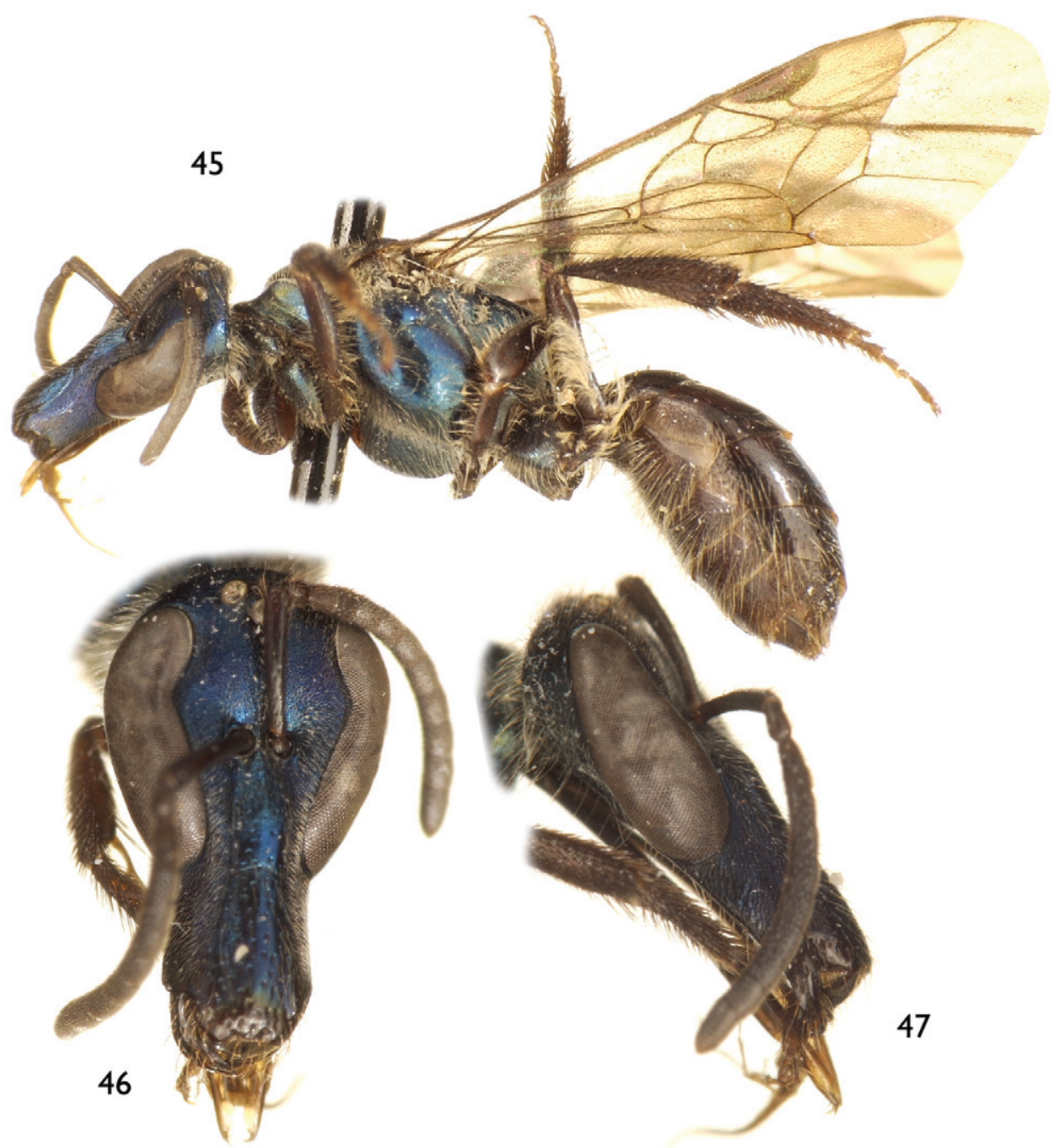

Figures 45-47. Holotype female of Chlerogella dolichorhina sp. n. 45 Lateral habitus 46 Facial aspect 35 Lateral aspect of head.

terior border. Distal hamuli arranged 2-1-2. Inner metatibial spur with seven branches (not including apical portion of rachis).

Clypeus and supraclypeal area imbricate with weak punctures separated by $0.5-1$ times a puncture width; face with small, contiguous punctures, more widely spaced in malar space; punctures of face blending to finely imbricate integument in ocellocular area and vertex, with punctures separated by $0.5-2$ times a puncture width; gena finely imbricate with small punctures separated by $1-3$ times a puncture width; postgena imbricate and impunctate. Pronotum imbricate with minute punctures separated by 1-3 times a puncture width; mesoscutum imbricate with punctures separated by a puncture 
width or less on lateral thirds and posteriorly, anteromedially punctures becoming exceedingly faint to absent; mesoscutellum imbricate with small punctures separated by a puncture width or less; metanotum imbricate with minute punctures separated by a puncture width or less. Preëpisternum finely imbricate with small punctures separated by 1-3 times a puncture width; mesepisternum strongly and coarsely, relatively dull, with coarse, shallow punctures separated by 1.5-4 times a puncture width; metepisternum faintly imbricate. Propodeum strongly imbricate. Metasoma finely imbricate.

Mandible dark brown except reddish at apex; labrum dark brown; clypeal apex black, remainder of clypeus and head dark metallic azurite blue, with weak purple highlights. Antenna dark brown. Mesosoma dark metallic azurite blue, with weak purple highlights (Fig. 45); tegula dark brown. Wing membranes lightly infumate; veins dark brown. Legs dark brown. Metasoma dark brown.

Pubescence white except intermingled with dark fuscous setae on metatibia and with dark fuscous setae predominant on tarsi, apicalmost metasomal segments, and pro- and mesotibiae.

Male: Unknown.

Etymology. The specific epithet is a combination of the Greek terms dolichos, meaning "long", and rhinos, meaning "nose".

\section{Chlerogella agaylei Engel, sp. $\mathbf{n}$.}

urn:Isid:zoobank.org:act:A2EB807F-FB58-4A15-86F6-9834F329E715

Figs 48-54, 68-69, Map 3

Holotype. ${ }^{\lambda}$, Ecuador: Napo, 1200 m, km 7.3 Sarayacu-Loreto rd., 20 July 1994, F. Génier, ex: feces trap (SEMC).

Paratype. ECUADOR: 19, same data as holotype (SEMC).

Diagnosis. Females of $C$. agaylei superficially resemble those of $C$. dolichorhina from which the former can be recognized by the smooth and shining integument of the mesepisternum and the brilliant integumental coloration of the head and mesosoma. Females of $C$. agaylei are also very similar to those of $C$. azurea in which the former tends to be slightly more dark blue and the antenna uniformly dark brown. The male can be distinguished from that of $C$. materdonnae by the strong azurite coloration and the structure of SIV (Fig. 54) and the terminalia (Figs 68-69) and from C. azurea by the structure SIV.

Description. Female: Total body length $8.45 \mathrm{~mm}$; forewing length $5.47 \mathrm{~mm}$. Head length $2.45 \mathrm{~mm}$, width $1.54 \mathrm{~mm}$. Clypeus beginning just below lower tangent of compound eyes. Malar space $44.8 \%$ compound eye length (malar length $0.60 \mathrm{~mm}$; compound eye length $1.34 \mathrm{~mm}$ ) (Figs 49-50). Upper interorbital distance $0.73 \mathrm{~mm}$; lower interorbital distance $0.52 \mathrm{~mm}$. Upper portion of pronotum medially depressed, not elongate, medially less than 0.25 times ocellar diameter in length; ventral portion of preëpisternal sulcus not broad, similar to scrobal sulcus and upper portion of preëpisternal sulcus; intertegular distance $1.25 \mathrm{~mm}$; mesoscutellum weakly convex, not bigibbous. Basal vein 


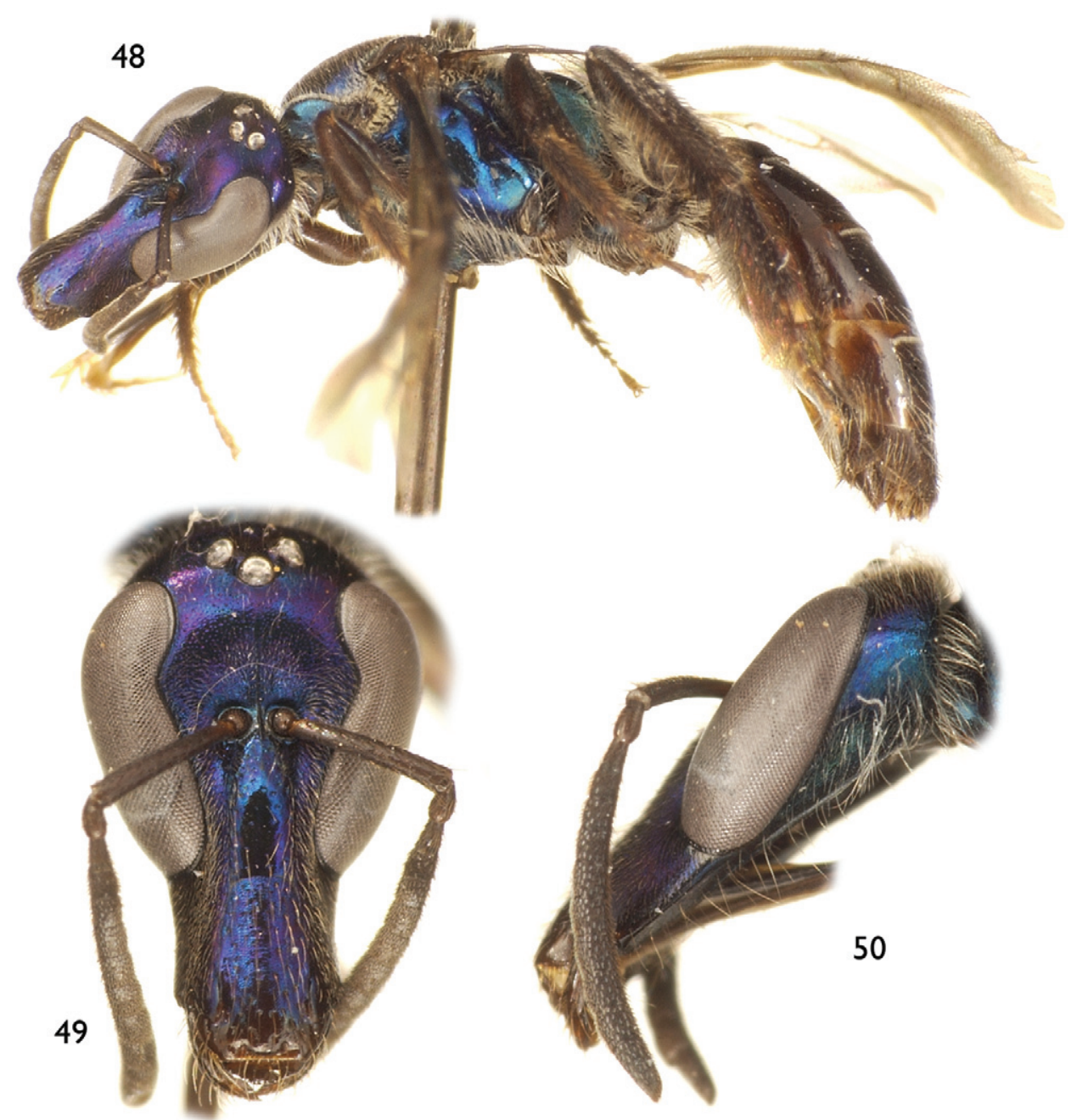

Figures 48-50. Paratype female of Chlerogella agaylei sp. n. 48 Lateral habitus 49 Facial aspect $\mathbf{5 0}$ Lateral aspect of head.

distad cu-a by two times vein width; 1 rs-m distad $1 \mathrm{~m}$-cu by two times vein width; $2 \mathrm{rs}-\mathrm{m}$ distad $2 \mathrm{~m}$-cu by eight times vein width, $2 \mathrm{rs}-\mathrm{m}$ weakly arched; first submarginal cell longer than combined lengths of second and third submarginal cells; second submarginal cell slightly narrowed anteriorly, anterior border of second submarginal cell along Rs about as along as that of third submarginal cell; posterior border of third submarginal cell slightly more than two times longer than anterior border. Distal hamuli arranged 2-1-2. Inner metatibial spur with five branches (not including apical portion of rachis).

Clypeus and supraclypeal area imbricate with weak punctures separated by $0.5-1.5$ times a puncture width; face with small, contiguous punctures, more widely spaced in malar space; punctures of face blending to imbricate integument in ocellocular area 


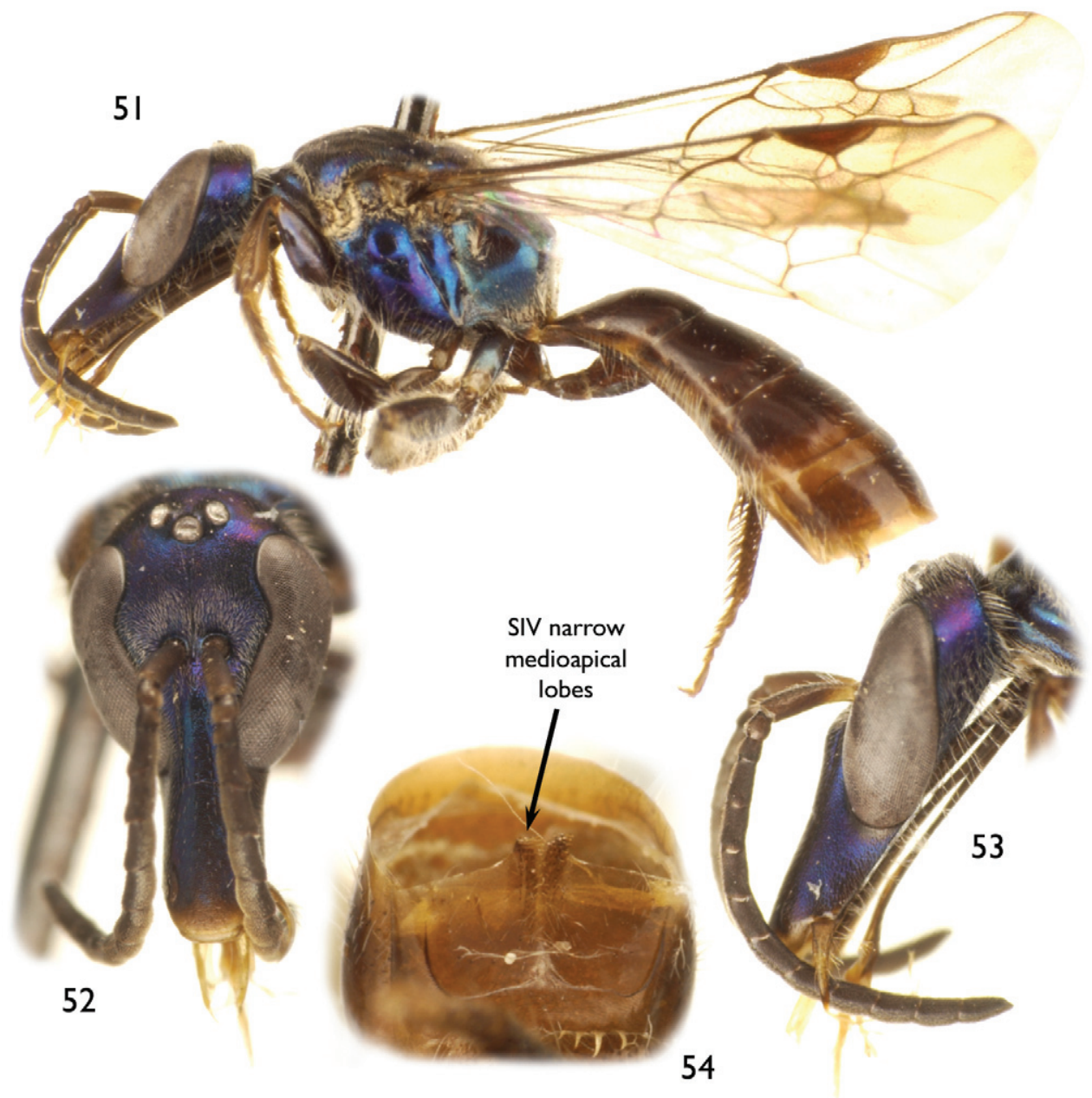

Figures 5 I-54. Holotype male of Chlerogella agaylei sp. n. 5 I Lateral habitus 52 Facial aspect 53 Lateral aspect of head $\mathbf{5 4}$ Apical sterna of metasoma.

and vertex, with punctures separated by $0.5-2$ times a puncture width; gena finely imbricate with small punctures separated by $0.5-2$ times a puncture width; postgena imbricate and impunctate. Pronotum imbricate with minute punctures separated by 1-3 times a puncture width; mesoscutum imbricate with punctures separated by a puncture width or less on lateral thirds and posteriorly, anteromedially punctures becoming exceedingly faint to absent; mesoscutellum finely imbricate with small punctures separated by a puncture width or less; metanotum imbricate with minute punctures separated by a puncture width or less. Preëpisternum finely imbricate with small punctures separated by $1-3$ times a puncture width; mesepisternum faintly imbricate and shining with weak punctures separated by $2-5$ times a puncture width; metepisternum faintly imbricate. Propodeum strongly imbricate. Metasoma finely imbricate. 
Mandible dark brown except reddish at apex; labrum dark brown; clypeal apex dark brown, remainder of clypeus and head azurite blue with strong purple highlights (Fig. 49). Antenna dark brown. Mesosoma azurite blue, with purple highlights but weaker than those of head (Fig. 48); tegula dark brown. Wing membranes lightly infumate; veins dark brown. Legs dark brown. Metasoma dark brown.

Pubescence white except intermingled with dark fuscous setae on metatibia and with dark fuscous setae predominant on tarsi, apicalmost metasomal segments, and pro- and mesotibiae.

Male: As described for the female except as follows: Total body length $8.88 \mathrm{~mm}$; forewing length $5.47 \mathrm{~mm}$. Head length $2.55 \mathrm{~mm}$, width $1.54 \mathrm{~mm}$. Clypeus beginning just below lower tangent of compound eyes. Malar space $46.7 \%$ compound eye length (malar length $0.63 \mathrm{~mm}$; compound eye length $1.35 \mathrm{~mm}$ ) (Figs 52-53). Upper interorbital distance $0.76 \mathrm{~mm}$; lower interorbital distance $0.39 \mathrm{~mm}$. First flagellomere about as long as pedicel, about as long as wide; second flagellomere two times length of first flagellomere; ventral surfaces of second through eleventh flagellomeres densely covered in placoid sensilla, placoid fields not disrupted. Intertegular distance 1.28 $\mathrm{mm}$; mesoscutellum not bigibbous. Inner metatibial spur serrate. Apical margin of SIII entire; apical margin of SIV with short, narrow median projection that is deeply emarginate medially (to form two very narrow paramedial projections) (Fig. 54); apical margin of SV entire; apical margin of SVI emarginate; terminalia as depicted in figures 68 and 69.

Mandible, labrum, and very narrow longitudinal mark at clypeal apex pale yellow.

Typical gender pilosity except postgena with numerous elongate, sinuate setae, such setae with short apical branches; inner surfaces of trochanters, mesofemur, and metacoxa with elongate, apically-plumose setae, similar setae on inner surfaces of metatrochanter, metafemur, and metatibia except largely simple and somewhat sinuate, those of metatibia particularly elongate, longer than metatibial width. Apical margin of SIII with diffuse fringe of moderate-length white setae; SIV with dense, short patches of fuscous setae on medioapical projections; SV with diffuse apicolateral areas of long white setae.

Etymology. The specific epithet is a patronym honoring my father, Rev. A. Gayle Engel.

\section{Chlerogella materdonnae Engel, sp. n.}

urn:lsid:zoobank.org:act:90CDFBB8-88FF-491B-B315-46A782333BBD

Figs 55-61, 70-71, Map 3

Holotype. $\widehat{\text { }}$, Ecuador: Tungurahua, Rio Pastaza, Pailon del Diablo, 5 km SE, II-181996, J.S. Ascher, flying along forest trail (SEMC).

Paratypes. Ecuador: 1 ${ }^{\lambda}$, Tungurahua, Pastaza Valley, Rio Topo, $1100 \mathrm{~m}$, 29.i.1986 [29 January 1986], M. Cooper (COOP); 1, Tungurahua, Pastaza Valley, Rio Topo, 1100 m, 20.xii.1982 [20 December 1982], M. Cooper (COOP); 1 万人, Napo, 5 km NE El Chaco, 11.ii.1983 [11 February 1983], L. Huggert (SEMC). 


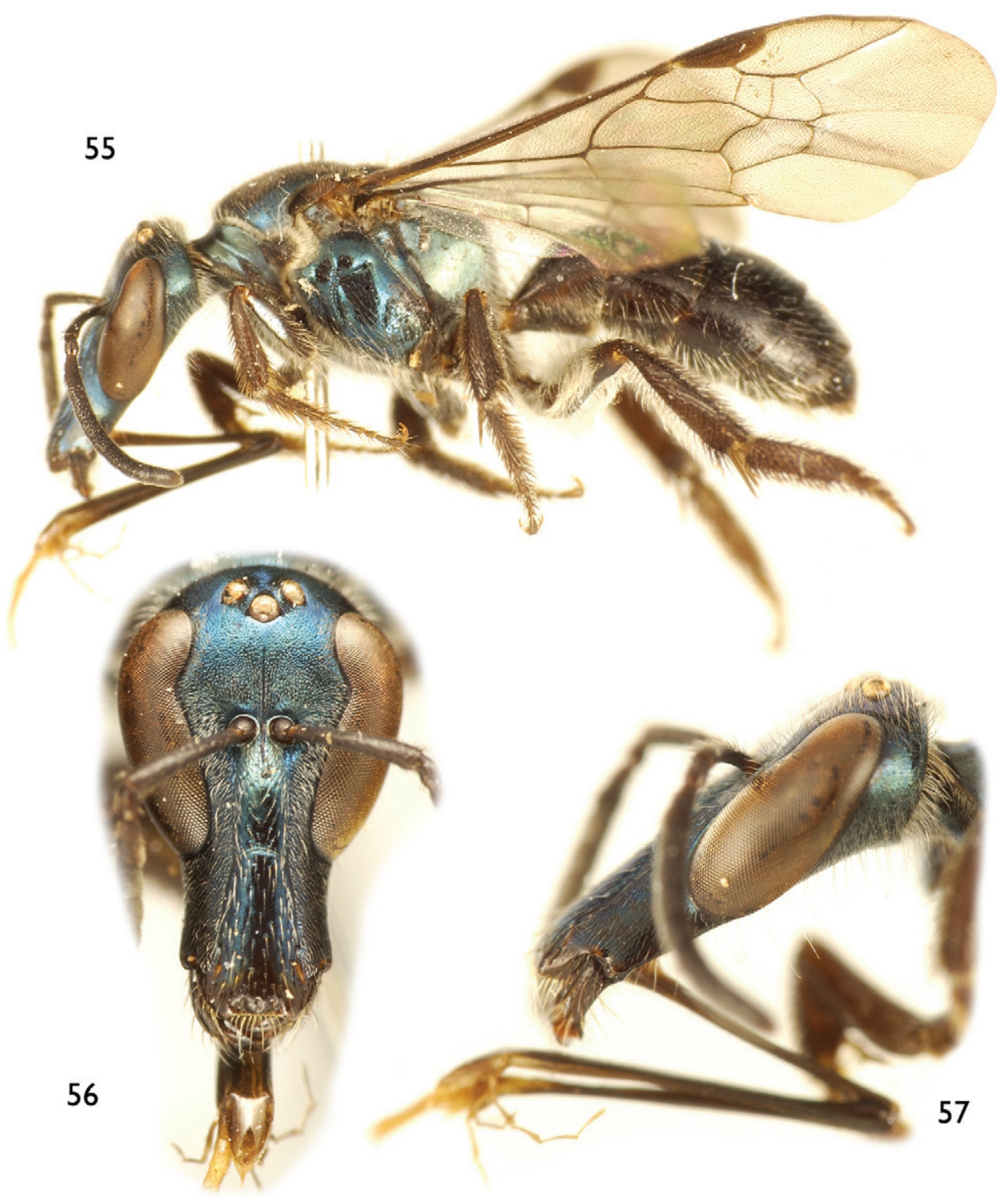

Figures 55-57. Female of Chlerogella materdonnae sp. n. 55 Lateral habitus 56 Facial aspect $\mathbf{5 7}$ Lateral aspect of head.

Diagnosis. Chlerogella materdonnae belongs to a complex of very similar metallic blue species with elongate malar spaces. The female is most similar to C. rostrata but differs by the brilliant and shiny caerulean blue color of the integument (Figs 55-56; $c f$. Figs 30-31) and the uniformly punctured mesepisternum (not more densely spaced ventrally as in $C$. rostrata, vide supra). The male can be distinguished from that of $C$. agalyei by the caerulean coloration and the structure of SIV (Fig. 61) and the terminalia (Figs 70-71). 


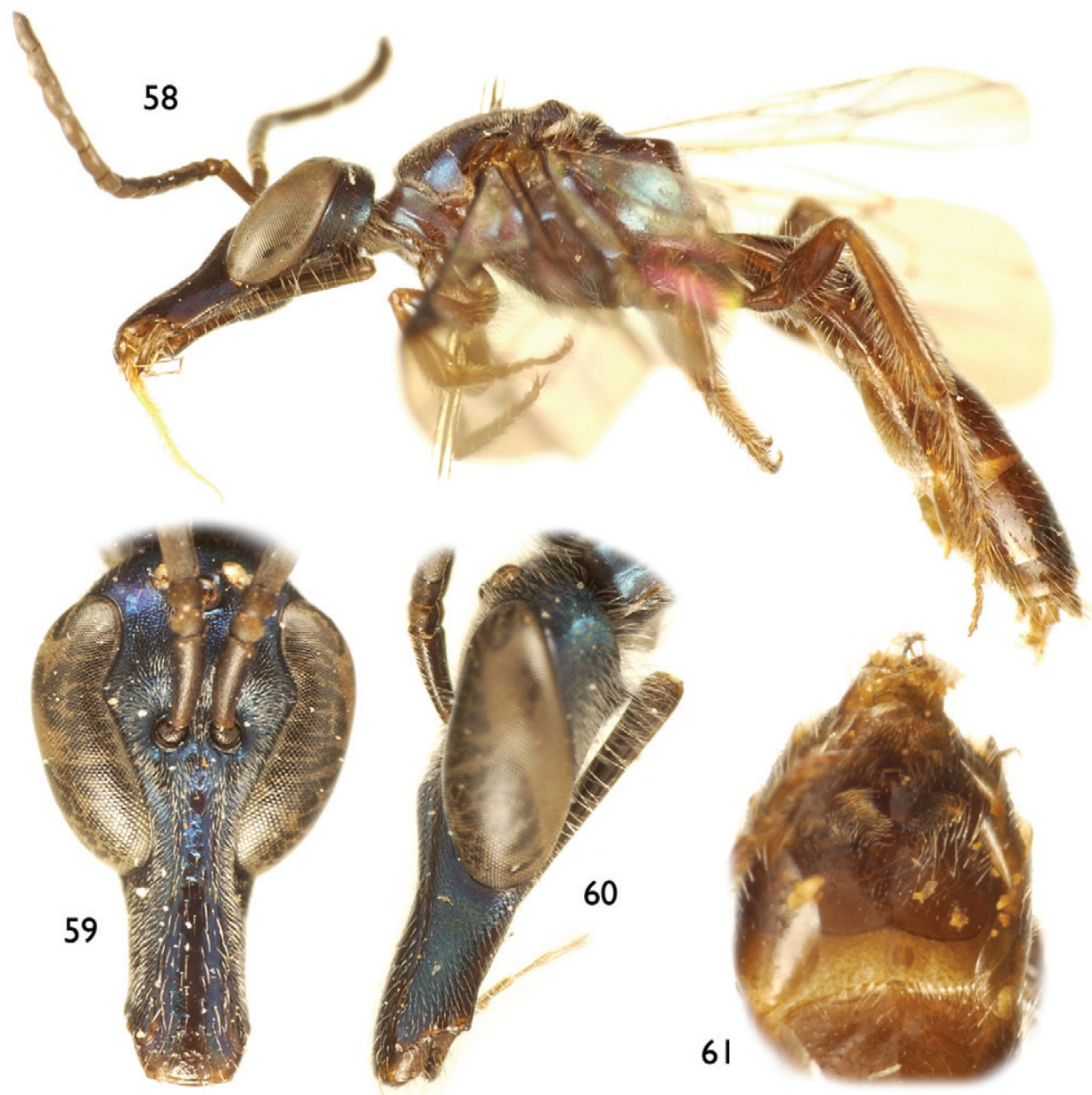

Figures 58-61. Male of Chlerogella materdonnae sp. n. 58 Lateral habitus 59 Facial aspect 60 Lateral aspect of head $\mathbf{6} \mathbf{I}$ Apical metasomal sterna.

Description. Female: Total body length $9.11 \mathrm{~mm}$; forewing length $6.20 \mathrm{~mm}$. Head length $2.71 \mathrm{~mm}$, width $1.74 \mathrm{~mm}$. Clypeus beginning at lower tangent of compound eyes. Malar space $43.9 \%$ compound eye length (malar length $0.65 \mathrm{~mm}$; compound eye length $1.48 \mathrm{~mm}$ ) (Figs 56-57). Upper interorbital distance $0.83 \mathrm{~mm}$; lower interorbital distance $0.63 \mathrm{~mm}$. Upper portion of pronotum medially depressed, not elongate, medially less than 0.25 times ocellar diameter in length; ventral portion of preëpisternal sulcus not broad, similar to scrobal sulcus and upper portion of preëpisternal sulcus; intertegular distance $1.43 \mathrm{~mm}$; mesoscutellum weakly convex, not bigibbous. Basal vein distad cu-a by three times vein width; $1 \mathrm{rs}-\mathrm{m}$ distad $1 \mathrm{~m}$-cu by two times vein width; 2 rs$\mathrm{m}$ distad $2 \mathrm{~m}$-cu by nine times vein width, $2 \mathrm{rs}-\mathrm{m}$ weakly arched; first submarginal cell longer than combined lengths of second and third submarginal cells; second submarginal cell slightly narrowed anteriorly, anterior border of second submarginal cell along Rs 
slightly longer than that of third submarginal cell; posterior border of third submarginal cell slightly more than two times longer than anterior border. Distal hamuli arranged 2-1-2. Inner metatibial spur with six branches (not including apical portion of rachis).

Clypeus and supraclypeal area imbricate with weak punctures separated by $0.5-1.5$ times a puncture width; face with small, contiguous punctures, more widely spaced in malar space; punctures of face blending to imbricate integument in ocellocular area and vertex, with punctures separated by $1-2$ times a puncture width; gena finely imbricate with small punctures separated by $0.5-2$ times a puncture width; postgena imbricate and impunctate. Pronotum imbricate with minute punctures separated by $1-3$ times a puncture width; mesoscutum imbricate with punctures separated by a puncture width or less on lateral thirds and posteriorly, anteromedially punctures becoming exceedingly faint to absent; mesoscutellum finely imbricate with small punctures separated by a puncture width or less; metanotum imbricate with minute punctures separated by a puncture width or less. Preëpisternum finely imbricate with small punctures separated by $1-3$ times a puncture width; mesepisternum imbricate with punctures separated by 2-4 times a puncture width; metepisternum faintly imbricate. Propodeum strongly imbricate. Metasoma finely imbricate.

Mandible dark brown except reddish at apex; labrum dark brown; clypeal apex dark brown, remainder of clypeus and head light metallic caerulean blue. Antenna dark brown. Mesosoma light metallic caerulean blue (Fig. 55); tegula dark brown. Wing membranes lightly infumate; veins dark brown. Legs dark brown. Metasoma dark brown.

Pubescence white except intermingled with dark fuscous setae on metatibia and with dark fuscous setae predominant on tarsi, apicalmost metasomal segments, and pro- and mesotibiae.

Male: As described for the female except as follows: Total body length 9.0-9.18 $\mathrm{mm}$; forewing length $6.13-6.15 \mathrm{~mm}$. Head length $2.58-2.60 \mathrm{~mm}$, width $1.59-1.60$ $\mathrm{mm}$. Clypeus beginning below lower tangent of compound eyes. Malar space 50.7$51 \%$ compound eye length (malar length $0.73 \mathrm{~mm}$; compound eye length $1.43-1.44$ $\mathrm{mm}$ ) (Figs 59-60). Upper interorbital distance 0.76-0.78 $\mathrm{mm}$; lower interorbital distance $0.42-0.43 \mathrm{~mm}$. First flagellomere about as long as pedicel, about as long as wide; second flagellomere 2.4 times length of first flagellomere; ventral surfaces of second through eleventh flagellomeres densely covered in placoid sensilla, placoid fields not disrupted. Intertegular distance 1.20-1.22 mm; mesoscutellum weakly bigibbous. Inner metatibial spur serrate. Apical margin of SIII entire; apical margin of SIV broadly concave medially and produced into short broad lobes lateral to concavity, without furrow in apical half of disc (Fig. 61); apical margin of SV entire; apical margin of SVI emarginate; terminalia as depicted in figures 70 and 71.

Mandible, labrum, and clypeal apex brown. Head and mesosoma light metallic caerulean blue except more deeply azurite colored on face and mesoscutum.

Typical gender pilosity except postgena with numerous elongate, sinuate setae, such setae with short apical branches; inner surfaces of trochanters, mesofemur, and metacoxa with elongate, apically-plumose setae, similar setae on inner surfaces of me- 
tatrochanter, metafemur, and metatibia except largely simple and somewhat sinuate, those of metatibia not particularly elongate, length of such setae not or scarcely longer than metatibial width. Apical margin of SIII with diffuse fringe of moderate-length white setae; SIV with small medioapical pads of short fuscous setae bordering medial emargination; SV with diffuse areas of moderate-length to long white setae.

Etymology. The specific epithet is a matronym combining the Latin term mater, meaning "mother", and Donna, in loving honor of my mother, Mrs. Donna G. Engel.

\section{Chlerogella eumorpha Engel, sp. n.}

urn:Isid:zoobank.org:act:F46DAF4B-A586-40D2-9201-9CFB0392EBFB

Figs 62-67, 72-73, Map 3

Holotype. + , Ecuador: Pichincha, Nambillo Valley near Mindo, 1450 m, 8.vi.1987 [8 June 1987], M. Cooper (COOP).

Paratypes. Ecuador: 1 ㅇ, $1 \overbrace{}^{\lambda}$, Pichincha, Nambillo Valley near Mindo, $1450 \mathrm{~m}$,

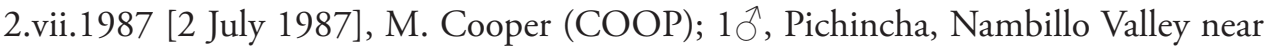
Mindo, 1450 m, 15.viii.1987 [15 August 1987], M. Cooper (COOP); 10, Pichincha, Nambillo Valley near Mindo, 1450 m, 16.viii.1987 [16 August 1987], M. Cooper (COOP); 1§̃, Pichincha, Los Bancos, 1100 m, 1.vi.1987 [1 June 1987], M. Cooper (COOP).

Diagnosis. Chlerogella eumorpha may be recognized most easily by the combination of a moderately long malar space (Figs 63-64, 66-67) and brilliant metallic blue on the head and mesosoma (Figs 62-67).

Description. Female: Total body length 7.49-7.52 mm; forewing length 5.67$5.79 \mathrm{~mm}$. Head length $2.29-2.30 \mathrm{~mm}$, width $1.69-1.71 \mathrm{~mm}$. Clypeus beginning at lower tangent of compound eyes. Malar space 17.6-17.7\% compound eye length (malar length $0.26 \mathrm{~mm}$; compound eye length $1.47-1.48 \mathrm{~mm}$ ) (Figs 63-64). Upper interorbital distance $0.78 \mathrm{~mm}$; lower interorbital distance $0.57-0.58 \mathrm{~mm}$. Upper portion of pronotum medially depressed, slightly elongate, medially less than an ocellar diameter in length; ventral portion of preëpisternal sulcus not broad, similar to scrobal sulcus and upper portion of preëpisternal sulcus; intertegular distance $1.31-1.35 \mathrm{~mm}$; mesoscutellum weakly convex, not bigibbous. Basal vein distad cu-a by three times vein width; $1 \mathrm{rs}$-m distad $1 \mathrm{~m}$-cu by two times vein width; $2 \mathrm{rs}-\mathrm{m}$ distad $2 \mathrm{~m}$-cu by five times vein width, $2 \mathrm{rs}-\mathrm{m}$ gently arched; first submarginal cell longer than combined lengths of second and third submarginal cells; second submarginal cell not narrowed anteriorly, anterior border of second submarginal cell along Rs slightly longer than that of third submarginal cell; posterior border of third submarginal cell about two times longer than anterior border. Distal hamuli arranged 2-1-2. Inner metatibial spur with four branches (not including apical portion of rachis).

Clypeus and supraclypeal area faintly imbricate with punctures separated by 1-2 times a puncture width; face with small, contiguous punctures, more widely spaced in malar space and bordering supraclypeal area; punctures of face blending to smooth in- 


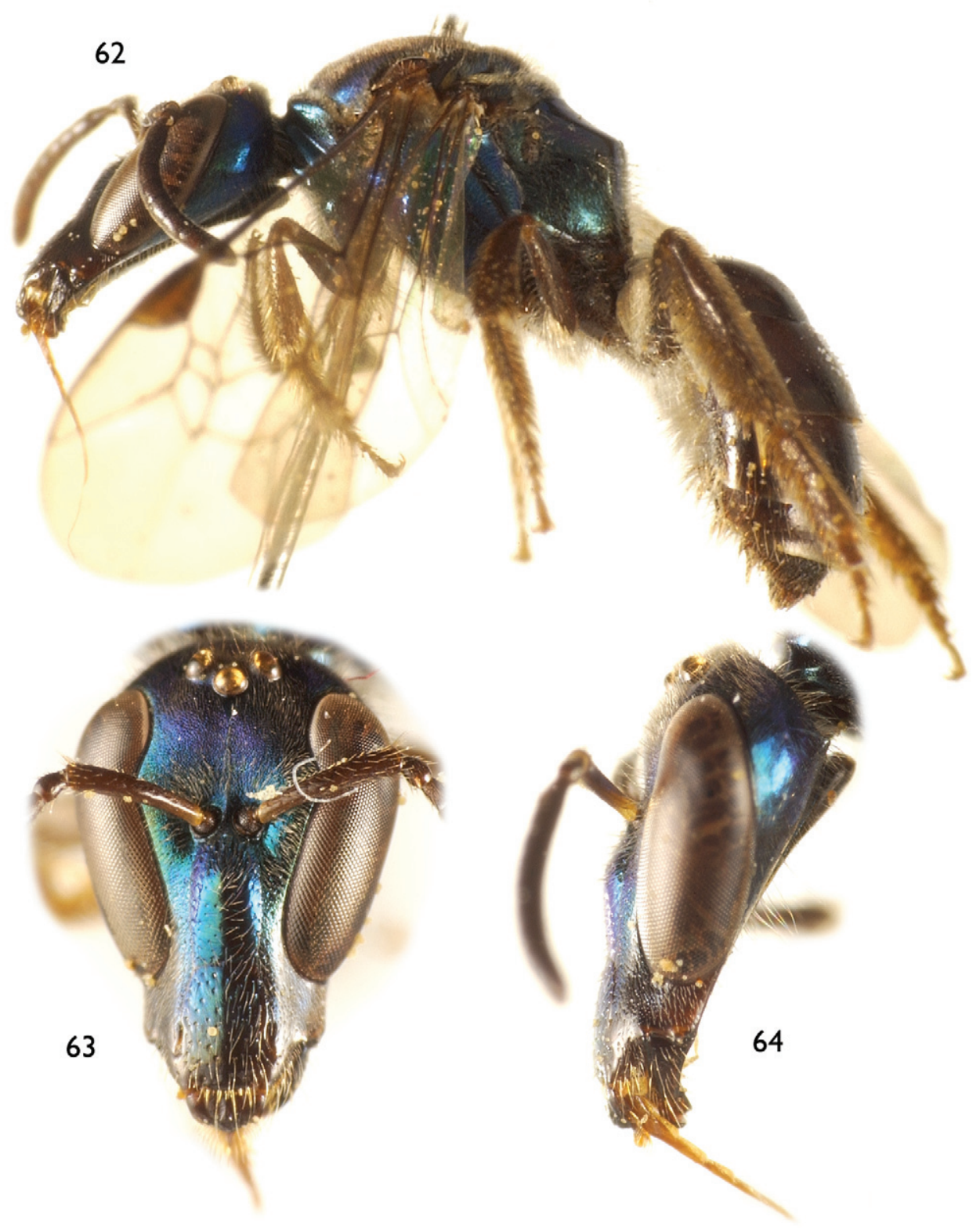

Figures 62-64. Holotype female of Chlerogella eumorpha sp. n. 62 Lateral habitus 63 Facial aspect 64 Lateral aspect of head.

tegument in ocellocular area and vertex, with punctures separated by $1-2$ times a puncture width; gena smooth with minute punctures separated by $1-3$ times a puncture width; postgena imbricate and impunctate. Pronotum finely imbricate with scattered minute punctures; mesoscutum smooth with small punctures separated by a puncture width, anteromedially punctures becoming exceedingly faint to absent and integu- 


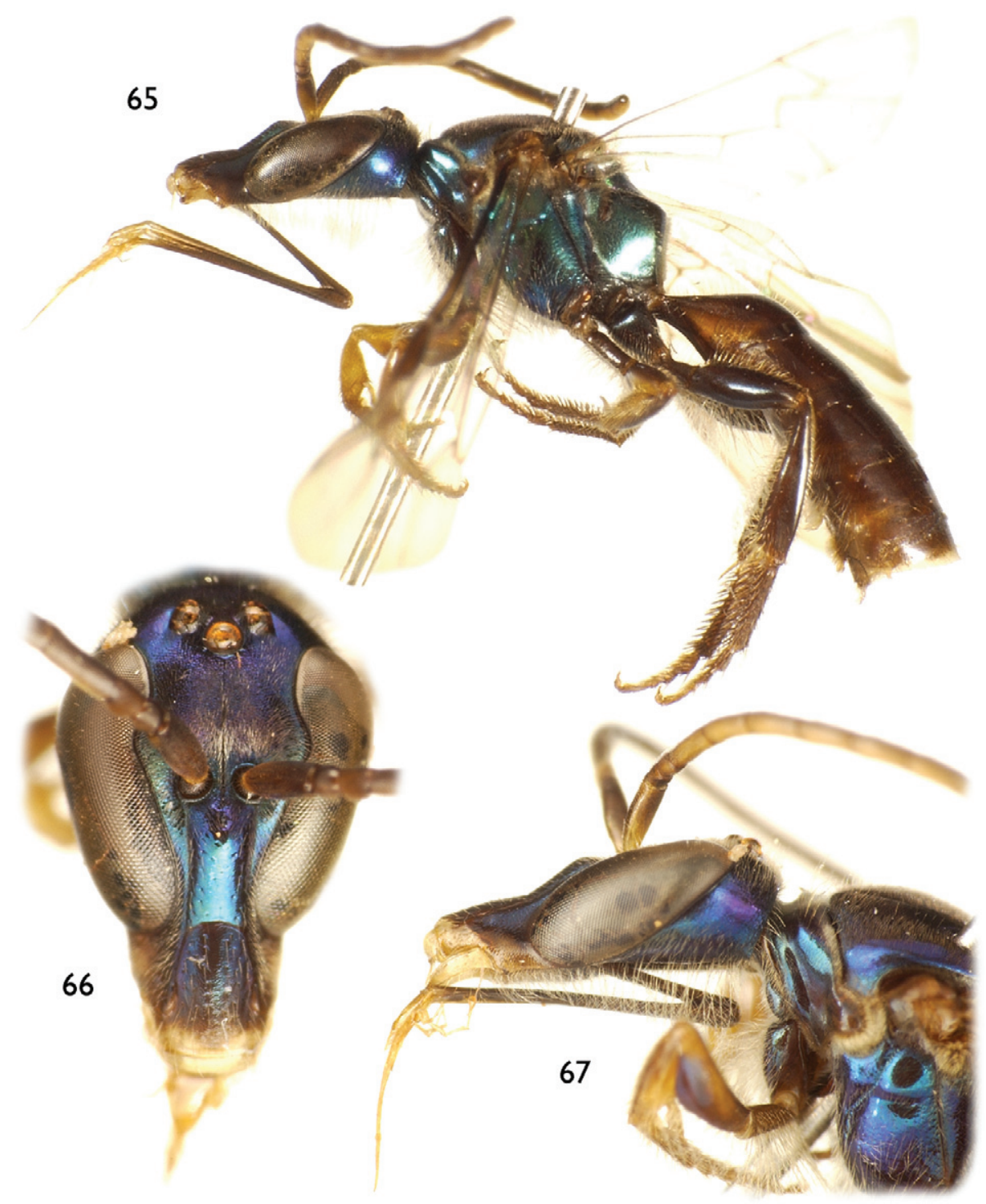

Figures 65-67. Paratype male of Chlerogella eumorpha sp. n. 65 Lateral habitus 66 Facial aspect 67 Lateral aspect of head.

ment finely imbricate; mesoscutellum and metanotum smooth with small punctures separated by a puncture width. Preëpisternum smooth with small punctures separated by 1-3 times a puncture width; mesepisternum smooth with small punctures separated by $2-6$ times a puncture width, punctures weak; metepisternum smooth. Propodeum strongly imbricate. Metasoma finely imbricate.

Mandible dark brown except reddish at apex; labrum dark brown; clypeal apex dark brown, remainder of clypeus and head brilliant metallic azurite blue, with 

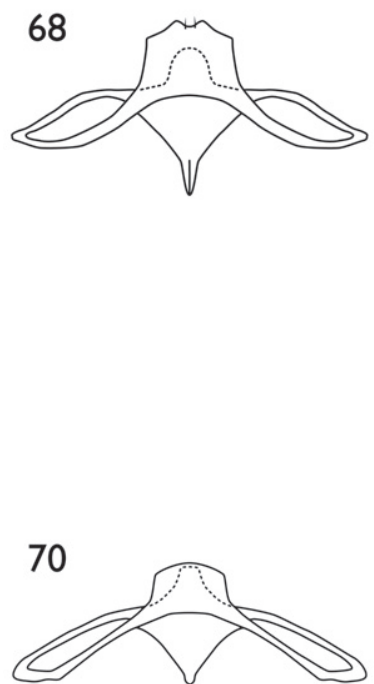

72
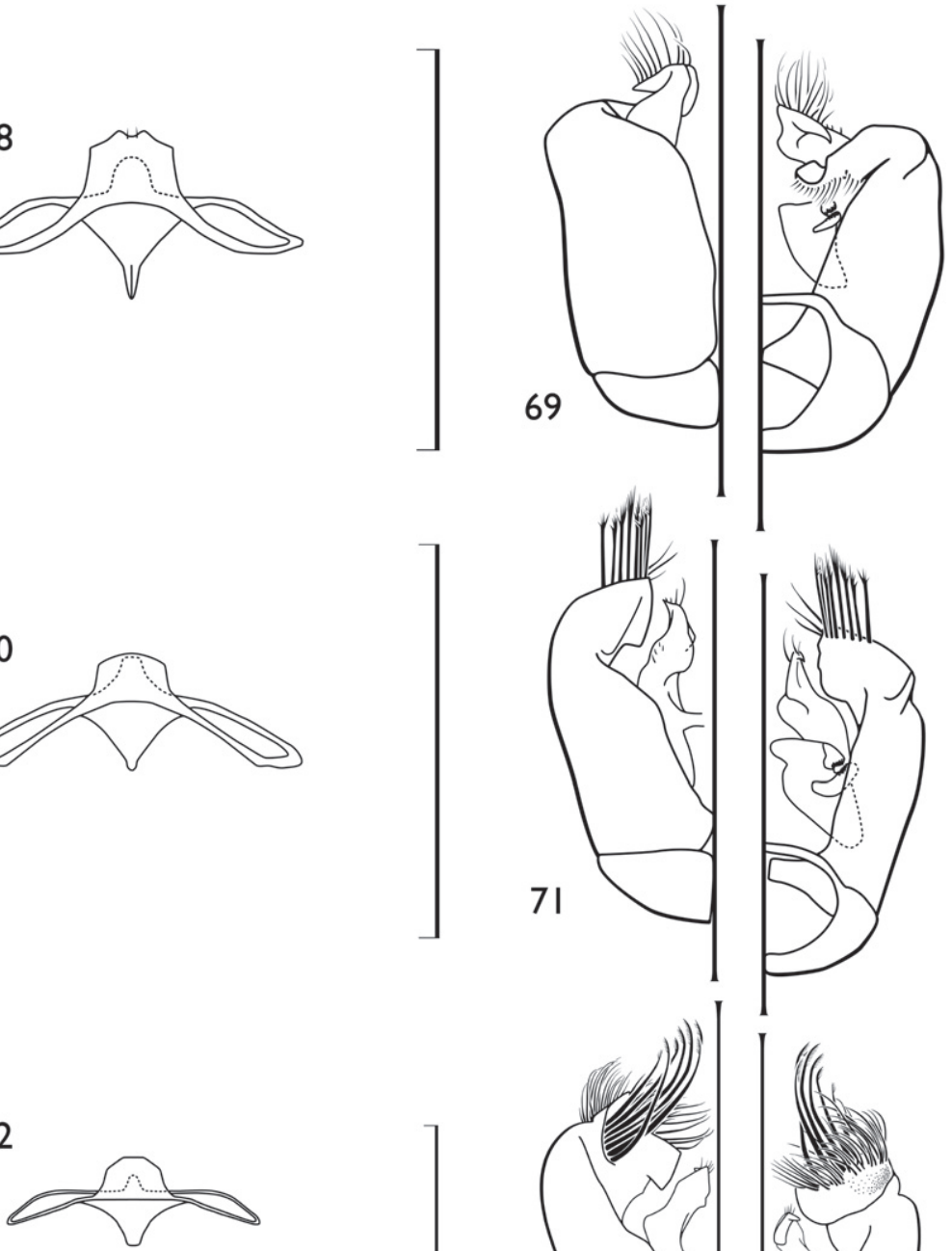

73
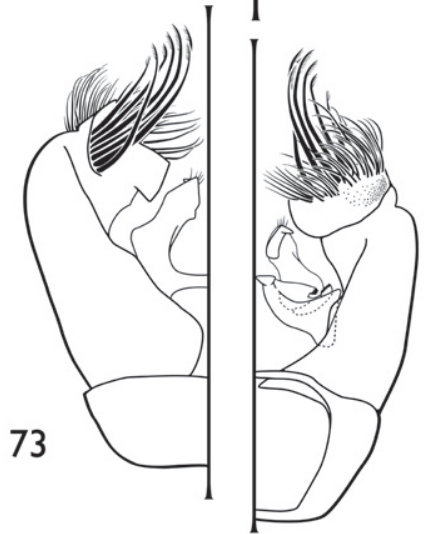

Figures 68-73. Male terminalia for some Ecuadorian Chlerogella species. 68 Chlerogella agaylei sp. n., hidden and fused sterna VII and VIII 69 C. agaylei sp. n., genital capsule (left is dorsal aspect, right is ventral aspect) $\mathbf{7 0}$ C. materdonnae sp. n., hidden and fused sterna VII and VIII $\mathbf{7 I}$ C. materdonnae sp. n., genital capsule (left is dorsal aspect, right is ventral aspect) $\mathbf{7 2}$ C. eumorpha sp. n., hidden and fused sterna VII and VIII 73 C. eumorpha sp. n., genital capsule (left is dorsal aspect, right is ventral aspect). All scale bars $=1 \mathrm{~mm}$. 
purple highlights. Antenna dark brown except extreme base of scape lighter. Mesosoma brilliant metallic azurite blue, with purple highlights (Fig. 62); tegula dark brown. Wing membranes weakly infumate; veins dark brown. Legs dark brown except procoxa metallic blue. Metasoma dark brown, with apical margins of TII-VI translucent brown.

Pubescence white to slightly golden except fuscous setae on tarsi, tibiae, inner surface of metatibia and fuscous setae intermingled on apical metasomal segments.

Male: As described for the female except as follows: Total body length 8.24-8.26 $\mathrm{mm}$; forewing length $5.73-5.93 \mathrm{~mm}$. Head length $2.24-2.32 \mathrm{~mm}$, width $1.56-1.61$ $\mathrm{mm}$. Clypeus beginning just above lower tangent of compound eyes. Malar space 17.6-17.8\% compound eye length (malar length $0.26 \mathrm{~mm}$; compound eye length $1.46-1.48 \mathrm{~mm}$ ) (Figs 66-67). Upper interorbital distance 0.70-0.73 mm; lower interorbital distance $0.36-0.39 \mathrm{~mm}$. First flagellomere about as long as pedicel, about as long as wide; second flagellomere 3.4 times length of first flagellomere; ventral surfaces of second through eleventh flagellomeres densely covered in placoid sensilla, placoid fields not disrupted. Intertegular distance $1.20-1.22 \mathrm{~mm}$; mesoscutellum not bigibbous. Inner metatibial spur serrate. Apical margin of SIII entire; apical margin of SIV medially broadly and weakly concave, with short, broad, setose lobes produced on either side of apical concavity, with disc weakly depressed medially bordering concavity; apical margin of SV entire; apical margin of SVI emarginate; terminalia as depicted in figures 72 and 73 .

Mandible, labrum, and clypeal apex pale yellow. Legs somewhat lighter than in female and with some metallic blue highlights.

Typical gender pilosity except postgena with numerous elongate, sinuate setae, such setae with short apical branches; posterior surface of procoxa, inner surfaces of trochanters (particularly dense on protrochanter), mesofemur, and metacoxa with elongate, apically-plumose setae, similar setae on inner surfaces of metatrochanter, metafemur, and metatibia except largely simple and somewhat sinuate, those of metatibia particularly elongate and sinuous at apices. Apical margin of SIII with diffuse fringe of moderate-length white setae; SIV with small medioapical pads of short fuscous setae on lobes bordering medial concavity; SV laterally with diffuse areas of long, inwardly-curved setae.

Etymology. The specific epithet is taken from the Greek term eumorpha, meaning "shapely".

Comments. Chlerogella eumorpha is remarkably similar to C. elysia (vide infra), which occurs in the same general region, despite the significant differences in their coloration. The terminalia of males do show some differences that appear to be species specific and no Augochlorini are currently known to have such dramatic differences in coloration (e.g., see examples discussed by Engel and Gonçalves2010). Thus, for the time being I conservatively consider these extreme morphs to be separate species rather than lump them under a single epithet. Certainly discovery of the nests and further investigation into the biology of these seemingly rare bees will help to further clarify the circumscription of this taxon. 


\section{Chlerogella borysthenis Engel, sp. n.}

urn:Isid:zoobank.org:act:C194957D-DE52-4D40-966F-2C983805DA81

Figs 74-76, Map 3

Holotype. O, Ecuador: Pichincha, Mindo, 1300 m, 7.vi.1987 [7 June 1987], M. Cooper (COOP).

Diagnosis. Chlerogella borysthenis from the northwestern side of the Ecuadorian Andes is superficially similar to $C$. breviceps, the latter from the eastern side of the Andes in Ecuador, but differs in the length of the malar space (Figs 75-76) and the dark and dull metallic greyish blue-green to greenish blue coloration of the head and mesosoma (Figs 74-76).

Description. Female: Total body length $8.22 \mathrm{~mm}$; forewing length $5.80 \mathrm{~mm}$. Head length $2.16 \mathrm{~mm}$, width $1.93 \mathrm{~mm}$. Clypeus beginning above lower tangent of compound eyes. Malar space $6.75 \%$ compound eye length (malar length $0.104 \mathrm{~mm}$; compound eye length $1.54 \mathrm{~mm}$ ) (Figs 75-76). Upper interorbital distance $0.91 \mathrm{~mm}$; lower interorbital distance $0.73 \mathrm{~mm}$. Upper portion of pronotum medially depressed, not elongate, medially less than 0.25 times ocellar diameter in length; ventral portion of preëpisternal sulcus not broad, similar to scrobal sulcus and upper portion of preëpisternal sulcus; intertegular distance $1.30 \mathrm{~mm}$; mesoscutellum weakly convex, not bigibbous. Basal vein distad cu-a by three times vein width; $1 \mathrm{rs}-\mathrm{m}$ distad $1 \mathrm{~m}$-cu by two times vein width; 2 rs-m distad $2 \mathrm{~m}$-cu by ten times vein width, $2 \mathrm{rs}-\mathrm{m}$ gently arched; first submarginal cell longer than combined lengths of second and third submarginal cells; second submarginal cell slightly narrowed anteriorly, anterior border of second submarginal cell along Rs slightly shorter than that of third submarginal cell; posterior border of third submarginal cell slightly more than 1.75 times longer than anterior border. Distal hamuli arranged 2-1-2. Inner metatibial spur with four branches (not including apical portion of rachis).

Clypeus and supraclypeal area imbricate with weak punctures separated by $0.5-2$ times a puncture width; face with small, nearly contiguous punctures, more widely spaced in malar space; punctures of face blending to faintly imbricate integument in ocellocular area and vertex, with punctures separated by a puncture width or less; gena faintly imbricate with small punctures separated by 1-2 times a puncture width; postgena imbricate and impunctate. Pronotum imbricate with minute punctures separated by $1-3$ times a puncture width; mesoscutum finely imbricate with small punctures separated by a puncture width or less, anteromedially punctures becoming faint; mesoscutellum faintly imbricate with small punctures separated by a puncture width or less; metanotum imbricate with minute punctures separated by a puncture width or less. Preëpisternum faintly imbricate with small punctures separated by $0.5-2$ times a puncture width; mesepisternum faintly imbricate with small punctures separated by $0.5-1.5$ times a puncture width; metepisternum faintly imbricate. Propodeum strongly imbricate. Metasoma weakly imbricate.

Mandible dark brown except reddish at apex; labrum dark brown; clypeal apex dark brown, remainder of clypeus and head dark greyish blue-green to greenish blue. Antenna dark brown. Mesosoma dark greyish blue-green to greenish blue (Fig. 74); 


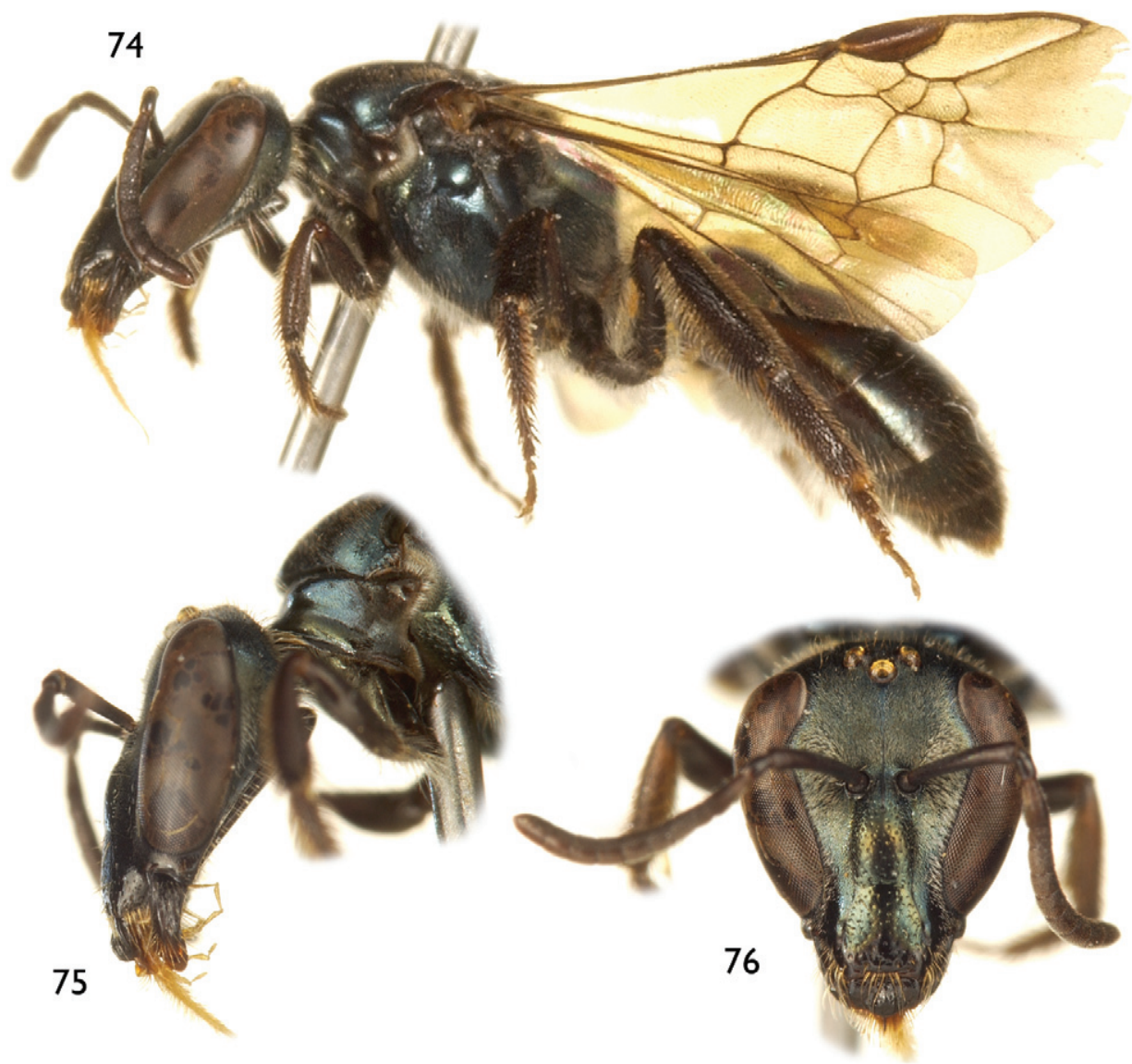

Figures 74-76. Holotype female of Chlerogella borysthenis, sp. n. 74 Lateral habitus 75 Lateral aspect of head 76 Facial aspect.

tegula brown. Wing membranes infumate; veins dark brown. Legs dark brown. Metasoma dark brown, with metallic highlights.

Pubescence white except fuscous on legs and apical metasomal segments.

Male: Unknown.

Etymology. The specific epithet is the name of one of the three Greek muses who were daughters of Apollo (Cephisso, Apollonis, and Borysthenis).

\section{Chlerogella breviceps Engel, sp. n.}

urn:Isid:zoobank.org:act:E56113D2-DD70-46C3-B021-BBA6DEB1CD5F

Figs 77-79, Map 3

Holotype. , Ecuador: Pastaza, Palora, 1000 m, 30.iv.1987 [30 April 1987], M. Cooper (COOP). 


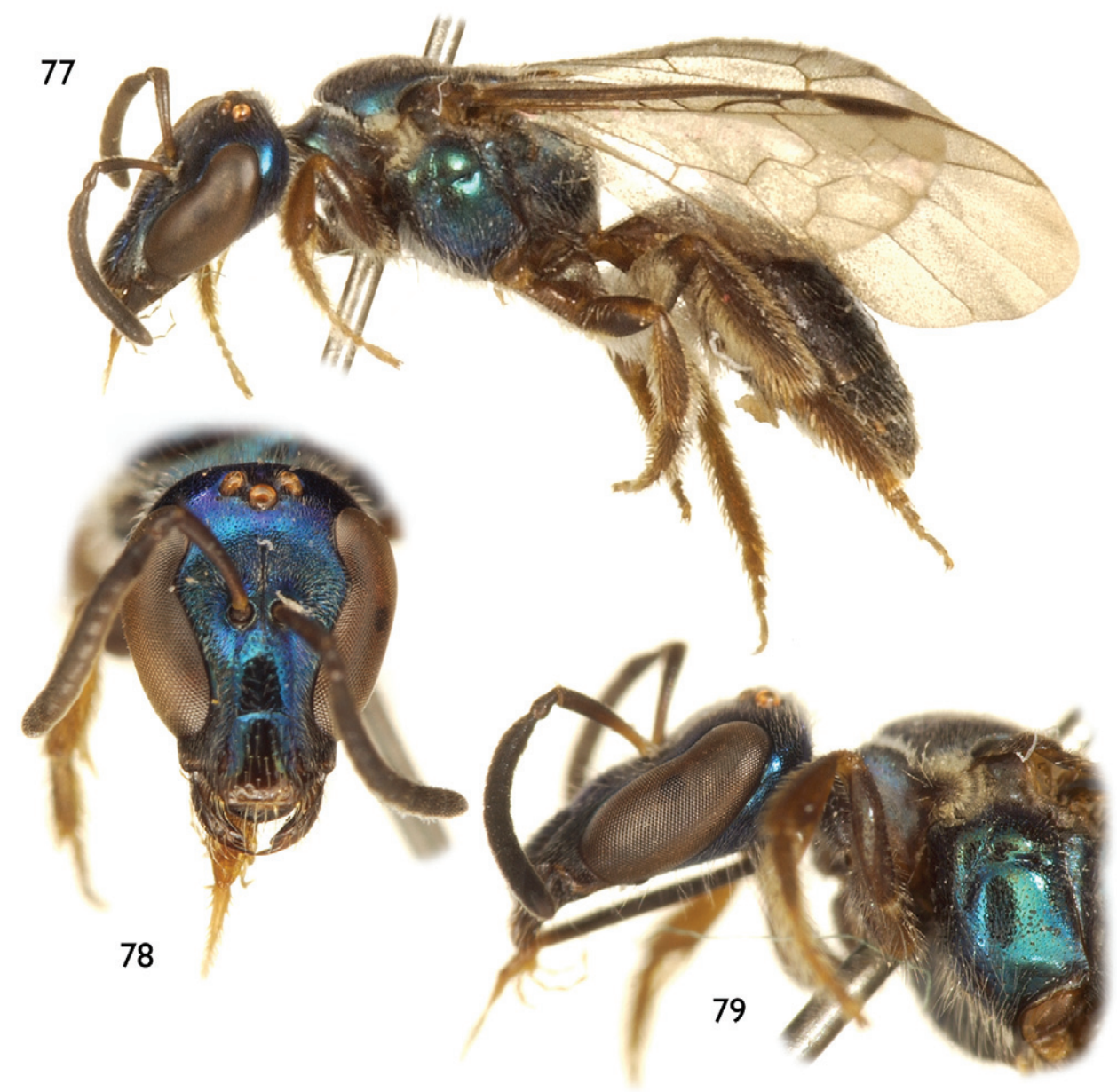

Figures 77-79. Holotype female of Chlerogella breviceps sp. n. 77 Lateral habitus 78 Facial aspect 79 Lateral aspect of head and anterior half of mesosoma.

Diagnosis. Chlerogella breviceps from the eastern side of the Andes in Ecuador is superficially most similar to $C$. borysthenis, itself from the northwestern side of the Ecuadorian Andes, but differs in the length of the malar space (Figs 78-79) and the brilliant and shining metallic blue coloration of the head and mesosoma (Figs 77-79).

Description. Female: Total body length $7.15 \mathrm{~mm}$; forewing length $5.27 \mathrm{~mm}$. Head length $1.82 \mathrm{~mm}$, width $1.51 \mathrm{~mm}$. Clypeus beginning above lower tangent of compound eyes. Malar space $10.4 \%$ compound eye length (malar length $0.13 \mathrm{~mm}$; compound eye length $1.25 \mathrm{~mm}$ ) (Figs 78-79). Upper interorbital distance $0.73 \mathrm{~mm}$; lower interorbital distance $0.52 \mathrm{~mm}$. Upper portion of pronotum medially depressed, not elongate, medially less than 0.25 times ocellar diameter in length; ventral portion of preëpisternal sulcus not broad, similar to scrobal sulcus and upper portion of preëpisternal sulcus; intertegular distance $1.25 \mathrm{~mm}$; mesoscutellum weakly convex, not bigibbous. Basal vein 
distad cu-a by two times vein width; 1 rs-m distad $1 \mathrm{~m}$-cu by two times vein width; 2 rs$\mathrm{m}$ distad $2 \mathrm{~m}$-cu by five times vein width, 2rs-m weakly arched; first submarginal cell longer than combined lengths of second and third submarginal cells; second submarginal cell not narrowed anteriorly, anterior border of second submarginal cell along Rs slightly longer than that of third submarginal cell; posterior border of third submarginal cell slightly more than 2.5 times longer than anterior border. Distal hamuli arranged 2-1-2. Inner metatibial spur with six branches (not including apical portion of rachis).

Clypeus and supraclypeal area imbricate with weak punctures separated by $0.5-2$ times a puncture width; face with small, nearly contiguous punctures, more widely spaced in malar space; punctures of face blending to smooth integument in ocellocular area and vertex, with punctures separated by 0.5-2 times a puncture width; gena smooth with small punctures separated by 1-3 times a puncture width; postgena imbricate and impunctate. Pronotum imbricate with minute punctures separated by 1-3 times a puncture width; mesoscutum smooth with small punctures separated by a puncture width or less; mesoscutellum as on mesoscutum; metanotum imbricate with small punctures separated by a puncture width or less. Preëpisternum smooth with small punctures separated by 0.5-2 times a puncture width; mesepisternum smooth with small punctures separated by 1-3 times a puncture width; metepisternum faintly imbricate. Propodeum strongly imbricate. Metasoma weakly imbricate.

Mandible dark brown except reddish at apex; labrum dark brown; clypeal apex dark brown, remainder of clypeus and head brilliant metallic azurite blue. Antenna dark brown. Mesosoma brilliant metallic azurite blue (Fig. 77); tegula dark brown. Wing membranes weakly infumate; veins dark brown. Legs dark brown except tarsomeres slightly lighter. Metasoma dark brown.

Pubescence white to slightly golden on legs.

Male: Unknown.

Etymology. The specific epithet is Latin term brevis (meaning, "short") and the suffix - ceps (derived from caput, meaning "head").

Comment. According to current maps Palora is located just inside Morona-Santiago along the border with Pastaza. It is unclear whether the Province is mislabeled on the holotype or whether the actual collection locality was within a couple of kilometers of Palora, just over the border into Pastaza Province.

\section{Chlerogella cooperella Engel, sp. n.}

urn:Isid:zoobank.org:act:73A0CE5E-DA28-42CB-9DDE-E7E5F458B71C

Figs 80-83, 87-89, Map 3

Holotype. đ̃, Ecuador: Morona-Santiago, Cord de Cutucu, 6 k E of Macas, 1100 m, 17.v.1981 [17 May 1981], M. Cooper (COOP).

Paratypes. ECUADOR: $1 \hat{\jmath}$, same data as holotype (COOP); $1 \hat{\jmath}$, Morona-Santiago, Cord de Cutucu, 6 k E of Macas, 1100 m, 13.v.1981 [13 May 1981], M. Cooper (COOP). 


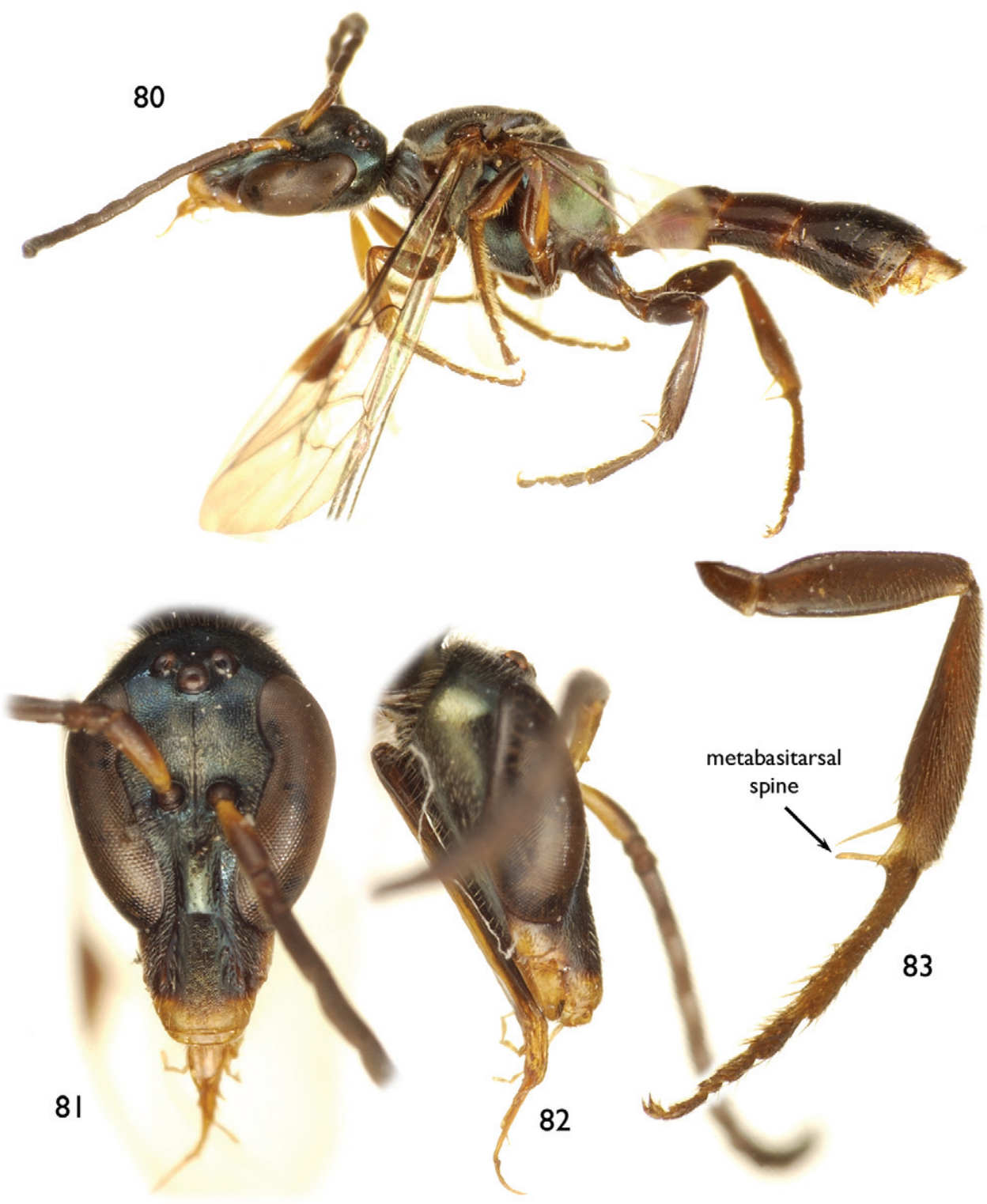

Figures 80-83. Holotype male of Chlerogella cooperella sp. n. 80 Lateral habitus $\mathbf{8 I}$ Facial aspect $\mathbf{8 2}$ Lateral aspect of head $\mathbf{8 3}$ Posterior view of hind leg from metatrochanter to meta-prestarsus, depicting spine at base of metabasitarsus.

Diagnosis. The male of C. cooperella is unique among species of Chlerogella for the presence of an elongate spine at the base of the metabasitarsus and orthogonal to the length of the tarsomere (Fig. 83).

Description. Male: Total body length 7.68-7.75 mm; forewing length $5.40-5.54$ $\mathrm{mm}$. Head length $2.08-2.10 \mathrm{~mm}$, width $1.41-1.42 \mathrm{~mm}$. Clypeus beginning above 
lower tangent of compound eyes. Malar space $17.7 \%$ compound eye length (malar length $0.23 \mathrm{~mm}$; compound eye length $1.30 \mathrm{~mm}$ ) (Figs 81-82). Upper interorbital distance $0.65-0.67 \mathrm{~mm}$; lower interorbital distance $0.34-0.36 \mathrm{~mm}$. First flagellomere about as long as pedicel, about as long as wide; second flagellomere 3.4 times length of first flagellomere; ventral surfaces of second through eleventh flagellomeres densely covered in placoid sensilla, placoid fields not disrupted. Upper portion of pronotum medially depressed, not elongate, medially less than 0.25 times ocellar diameter in length; ventral portion of preëpisternal sulcus not broad, similar to scrobal sulcus and upper portion of preëpisternal sulcus; intertegular distance $1.12-1.15 \mathrm{~mm}$; mesoscutellum weakly convex, not bigibbous. Basal vein distad cu-a by three times vein width; $1 \mathrm{rs}-\mathrm{m}$ distad $1 \mathrm{~m}$-cu by three times vein width; $2 \mathrm{rs}-\mathrm{m}$ distad $2 \mathrm{~m}$-cu by six times vein width, 2rs-m relatively straight; first submarginal cell longer than combined lengths of second and third submarginal cells; second submarginal cell slightly narrowed anteriorly, anterior border of second submarginal cell along Rs about as along as that of third submarginal cell; posterior border of third submarginal cell slightly more than two times longer than anterior border. Distal hamuli arranged 2-1-2. Inner base of metabasitarsus with elongate spine orthogonal to length of metabasitarsus (Fig. 83); inner metatibial spur pectinate with eight short branches (not including apical portion of rachis). Apical margins of SIII-V entire; apical margin of SVI emarginate; terminalia as depicted in figures $87-89$.

Clypeus and supraclypeal area imbricate with weak punctures separated by 1-2 times a puncture width; face with small, contiguous punctures, more widely spaced in malar space; punctures of face blending to smooth integument in ocellocular area, with punctures separated by $2-3$ times a puncture width, then to imbricate on vertex with punctures separated by 1-2 times a puncture width; gena smooth with small punctures separated by $2-3$ times a puncture width; postgena imbricate and impunctate. Pronotum imbricate with minute punctures separated by $1-3$ times a puncture width; mesoscutum imbricate with small punctures separated by a puncture width or less, anteromedially punctures becoming faint to absent; mesoscutellum imbricate with small punctures separated by a puncture width or less; metanotum imbricate with. Preëpisternum imbricate with small punctures separated by a puncture width or less; mesepisternum imbricate with small punctures separated by 0.5-3.5 times a puncture width; metepisternum faintly imbricate. Propodeum strongly imbricate. Metasoma finely imbricate.

Mandible yellow; labrum yellow; clypeal apex yellow, remainder of clypeus and face dark, dull metallic greyish blue, gena and postgena more greyish green. Antenna dark brown except base and ventral surface of scape lighter brown. Mesosoma dark, dull metallic greyish blue above and greyish green laterally (Fig. 80); tegula dark brown. Wing membranes lightly infumate; veins dark brown. Legs dark brown except anterior legs lighter and midlegs with lighter areas posteriorly. Metasoma dark brown.

Pubescence white. Typical gender pilosity except postgena with some elongate, sinuate setae, such setae with short apical branches. Apical margin of SIII without fringe; SIV with diffuse apicolateral areas of long, white setae; SV laterally with diffuse areas of long, inwardly-curved setae. 
Female: Unknown.

Etymology. The specific epithet is the diminutive of a patronym honoring Martin Cooper, Wiltshire, UK, collector of these and numerous other fine bees from the Neotropical Region.

\section{Chlerogella silvula Engel, sp. n.}

urn:lsid:zoobank.org:act:5912B372-09EA-48B7-9D05-A6FA2FE1AF7E

Figs 84-86, 90-91, Map 3

Holotype. ふै, Ecuador: Napo, Muyuna, 500 m, 5 km W. of Tena, 23.iv.1981 [23 April 1981], M. Cooper (COOP).

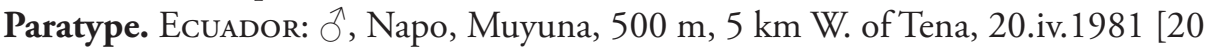
April 1981], M. Cooper (COOP).

Diagnosis. This species is very close to C. octogesima (Brooks and Engel) differing from that species by the more diffuse setae on SIII and SIV (developed into more dense fringes in $C$. octogesima), by the distinctly and greatly elongate diffuse apicolateral setae on SV (such elongate setae absent in C. octogesima), by the ventral fringe of setae on the ventral gonostylar process being elongate and not greatly thickened (Fig. 91) (decreasing in length to very short apically on ventral gonostylar process in C. octogesima, these same setae are distinctly thickened and curved, almost hooked, at their apices), and by the presence of greatly elongate setae dorsoapically on the penis valves (not present in C. octogesima).

Description. Male: Total body length 6.47-6.54 mm; forewing length 4.53$4.60 \mathrm{~mm}$. Head length 1.74-1.80 mm, width 1.25-1.28 mm. Clypeus beginning slightly above lower tangent of compound eyes. Malar space 11.6-13.9\% compound eye length (malar length $0.13-0.16 \mathrm{~mm}$; compound eye length $1.12-1.15 \mathrm{~mm}$ ) (Figs 85-86). Upper interorbital distance 0.63-0.64 mm; lower interorbital distance $0.30-0.34 \mathrm{~mm}$. First flagellomere about as long as pedicel, about as long as wide; second flagellomere 2.8 times length of first flagellomere; ventral surfaces of second through eleventh flagellomeres densely covered in placoid sensilla, placoid fields not disrupted. Upper portion of pronotum medially depressed, not elongate, medially less than 0.25 times ocellar diameter in length; ventral portion of preëpisternal sulcus not broad, similar to scrobal sulcus and upper portion of preëpisternal sulcus; intertegular distance 0.83-0.94 mm; mesoscutellum weakly convex, not bigibbous. Basal vein distad cu-a by three times vein width; $1 \mathrm{rs}-\mathrm{m}$ distad $1 \mathrm{~m}$-cu by four times vein width; 2 rs-m distad $2 \mathrm{~m}$-cu by five times vein width, 2 rs-m straight; first submarginal cell longer than combined lengths of second and third submarginal cells; second submarginal cell not narrowed anteriorly, anterior border of second submarginal cell along Rs slightly shorter than that of third submarginal cell; posterior border of third submarginal cell slightly more than two times longer than anterior border. Distal hamuli arranged 2-1-2. Inner metatibial spur minutely ciliate. Apical margin of SIII entire; apical margin of SIV entire, without furrow in apical half 


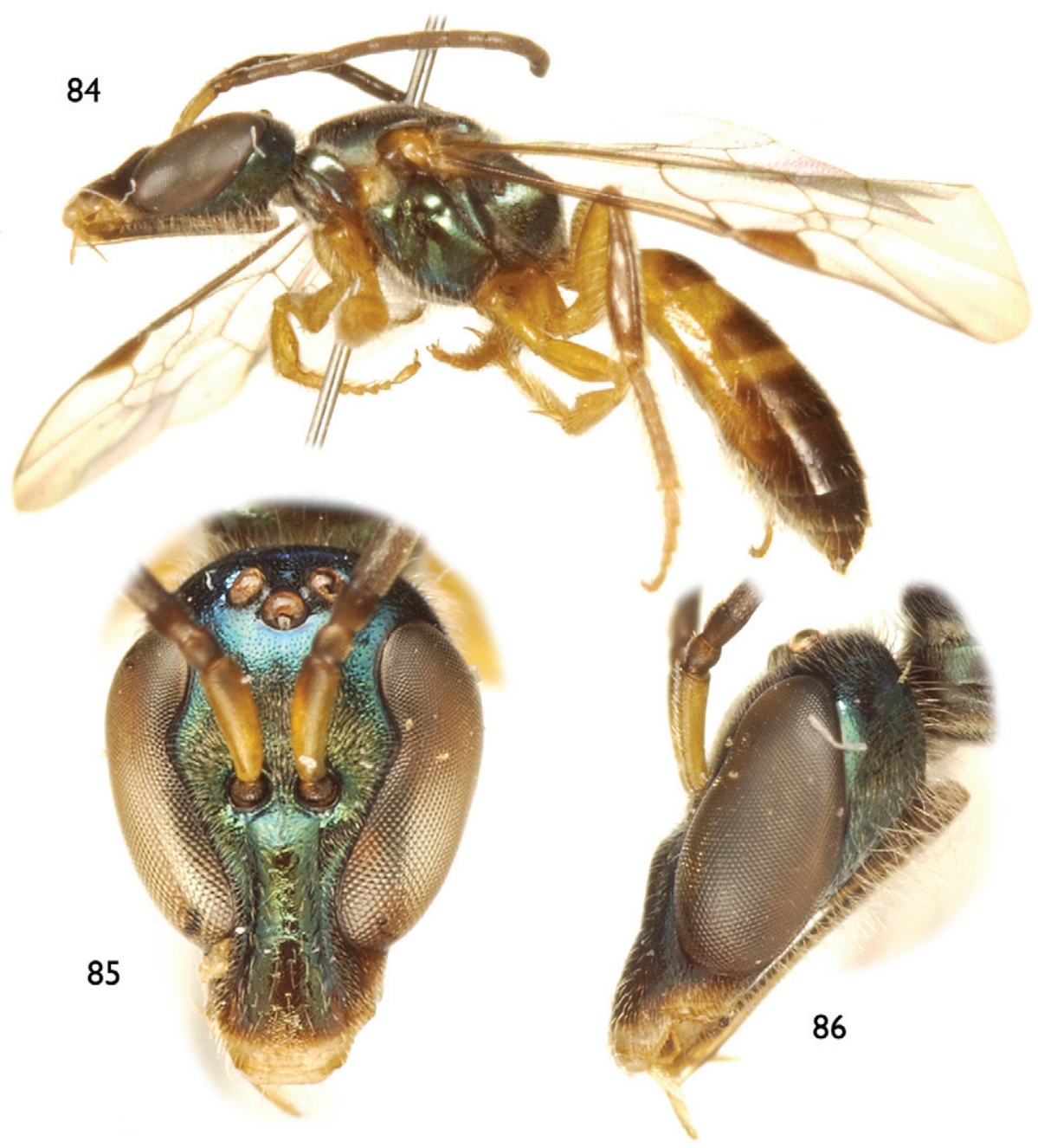

Figures 84-86. Holotype male of Chlerogella silvula sp. n. 84 Lateral habitus 85 Facial aspect 86 Lateral aspect of head.

of disc; apical margin of SV entire; apical margin of SVI emarginate; terminalia as depicted in figures 90 and 91 .

Clypeus and supraclypeal area faintly imbricate with weak punctures separated by 0.5-1.5 times a puncture width; face with small, contiguous punctures, more widely spaced in malar space; punctures of face blending to smooth integument in ocellocular area and vertex, with punctures separated by $1-2.5$ times a puncture width; gena smooth with small punctures separated by $1-3$ times a puncture width; postgena imbricate and impunctate. Pronotum smooth with scattered minute punctures; mesoscutum smooth with small punctures separated by 1-2.5 times a puncture width; mesoscutellum smooth with small punctures separated by $1-2$ times a puncture width; metanotum smooth with minute punctures separated by 1-3 times a puncture width. 

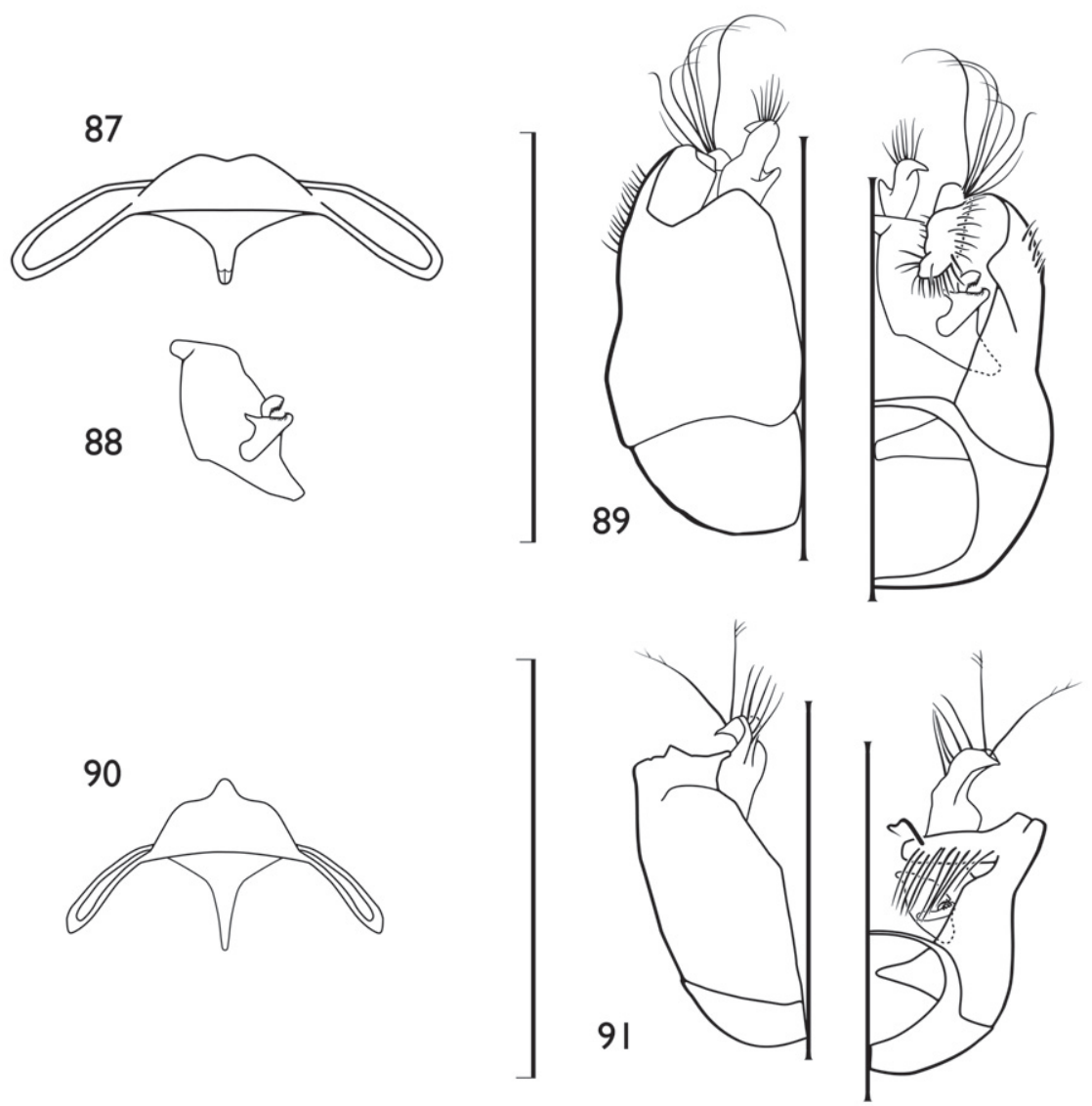

Figures 87-9 I. Male terminalia for some Ecuadorian Chlerogella species. 87 Chlerogella cooperella sp. n., hidden and fused sterna VII and VIII 88 Detail of volsella for C. cooperella sp. n. 89 C. cooperella sp. n., genital capsule (left is dorsal aspect, right is ventral aspect) $\mathbf{7 0}$ C. silvula sp. n., hidden and fused sterna VII and VIII 7 I C. silvula sp. n., genital capsule (left is dorsal aspect, right is ventral aspect). All scale bars $=1 \mathrm{~mm}$.

Preëpisternum smooth with small punctures separated by $2-5$ times a puncture width; mesepisternum smooth with small punctures separated by 2-6 times a puncture width; metepisternum smooth. Propodeum strongly imbricate. Metasoma weakly imbricate.

Mandible yellow except reddish at apex; labrum yellow; clypeal apex yellow, remainder of clypeus and head brilliant metallic green, with copper highlights, coloration more bluish on vertex. Antenna brown except scape largely yellow. Mesosoma brilliant metallic green, with copper highlights (Fig. 84), coloration more blue on mesosomal dorsum; pronotal lobe amber; tegula amber. Wing membranes lightly infumate; veins brown. Legs amber. Metasoma dark brown except SI-III amber, TI-III largely amber except brown on apical margin TI, apical third TII, and apical half TIII, tergal margins translucent brown. 
Pubescence white. Typical gender pilosity except postgena with elongate, sinuate setae, such setae with short apical branches and more dense anteriorly; inner surfaces of trochanters, mesofemur, and metacoxa with elongate, apically-plumose setae, similar setae on inner surfaces of metatibia except simple and somewhat sinuate. Apical margin of SIII-V laterally with diffuse patches of long setae, those on SV particularly elongate.

Female: Unknown.

Etymology. The specific epithet is a diminutive of the Latin term silva, meaning "forest".

\section{Chlerogella octogesima (Brooks \& Engel), comb. $n$.}

Map 3

Ischnomelissa octogesima Brooks and Engel, 1998: 187. Moure et al., 2007: 800; Engel and Brooks, 2002: 5.

Holotype. Ô, Ecuador: Napo, Misahualli, 1 hr. down Río Napo, 19 November 1983, L. Huggert (PMAE).

Diagnosis. Refer to diagnosis for C. silvula (vide supra).

Description. Modified after Brooks and Engel (1998): Male: Total body length $6.67 \mathrm{~mm}$; forewing length $4.58 \mathrm{~mm}$. Head length $1.73 \mathrm{~mm}$, width $1.19 \mathrm{~mm}$. Distal three-quarters of clypeus extending below lower tangent of compound eyes. Malar space about as long as basal mandibular width. Upper interorbital distance 0.58 $\mathrm{mm}$; lower interorbital distance $0.37 \mathrm{~mm}$. First flagellomere about as long as pedicel, about as long as wide and about one-half length of second flagellomere; ventral surfaces of second through eleventh flagellomeres densely covered in placoid sensilla, placoid fields not disrupted. Upper portion of pronotum medially depressed, not elongate, medially less than 0.25 times ocellar diameter in length; ventral portion of preëpisternal sulcus not broad, similar to scrobal sulcus and upper portion of preëpisternal sulcus; mesoscutellum weakly convex, not bigibbous. Basal vein distad cu-a by three times vein width; $1 \mathrm{rs}-\mathrm{m}$ distad $1 \mathrm{~m}$-cu by three times vein width; 2 rs- $m$ distad $2 \mathrm{~m}$-cu by six times vein width, 2 rs-m relatively straight; first submarginal cell longer than combined lengths of second and third submarginal cells; second submarginal cell slightly narrowed anteriorly, anterior border of second submarginal cell along Rs shoter than that of third submarginal cell; posterior border of third submarginal cell about 2.5 times as long as anterior border. Distal hamuli arranged 2-1-2. Inner metatibial spur serrate. Ventral fringe of setae on ventral gonostylar process decreasing in length to very short apically and distinctly thickened and curved, almost hooked, at their apices; penis valves lacking elongate setae dorsoapically.

Clypeus and supraclypeal area faintly imbricate with weak punctures separated by $0.5-1.5$ times a puncture width; face with small, contiguous punctures, more widely 
spaced in malar space; punctures of face blending to smooth integument in ocellocular area and vertex, with punctures separated by 1-2.5 times a puncture width; gena smooth with small punctures separated by 1-3 times a puncture width; postgena imbricate and impunctate. Pronotum smooth with scattered minute punctures; mesoscutum faintly imbricate with minute punctures separated by 1-3.0 times a puncture width; mesoscutellum as on mesoscutum. Preëpisternum smooth with faint contiguous punctures; mesepisternum finely imbricate with minute punctures separated by 1-3 times a puncture width; metepisternum smooth. Propodeum strongly imbricate. Metasoma weakly imbricate.

Mandible pale with black apex; labrum, clypeal apex, and apical half of malar space pale; antenna brown; remainder of head and mesosoma metallic green, except tegula brown amber and semi-translucent. Legs amber except outer surface of metafemur slightly darker. Metasomal TI-III with apical half brown, basal half amber; TIV-VII entirely brown.

Pubescence pale white; setae of mesoscutellum of moderate length. Terga with scattered simple setae progressively becoming longer and more numerous on apical terga; SI and SII with scattered simple setae; SIII with strong apical fringe of setae and SIV with less strong but very distinct brush of setae; SV and SVI with a less dense preapical band of setae.

Female: Unknown.

Comments. The female for C. octogesima remains unknown and, given the similarities of the males of $C$. octogesima and $C$. silvula, may prove difficult to distinguish if not captured alongside males. The species was originally placed in Ischnomelissa based on an incomplete knowledge of variation in Chlerogella. Given that the species had a short head and that the female was unknown (the most significant character at that time being the inner metatibial spur of females), the species was attributed to Ischnomelissa as no Chlerogella were known to have short malar spaces and despite the more elaborate and contorted gonostylar process which itself was not known among the otherwise relatively simple species of Ischnomelissa (but again, the genitalia of Chlerogella males was almost entirely unknown in 1998 as even the growing number of new, undescribed species at that date were known principally from females). It is now understood that malar length alone cannot exclude this species from Chlerogella and, more importantly, the structure of the gonostylar process is distinctive to Chlerogella (refer to the generic account, vide supra). Accordingly, this species is herein transferred to Chlerogella.

\section{Chlerogella mourella Engel}

Figs 92-94, Map 3

Chlerogella mourella Engel, 2003b: 135. Moure et al., 2007: 794.

Holotype. + , Ecuador: Napo, Sierra Azul, 2300 m, 21-22 April 1996, P. Hibbs, ex: flight intercept trap (SEMC). 


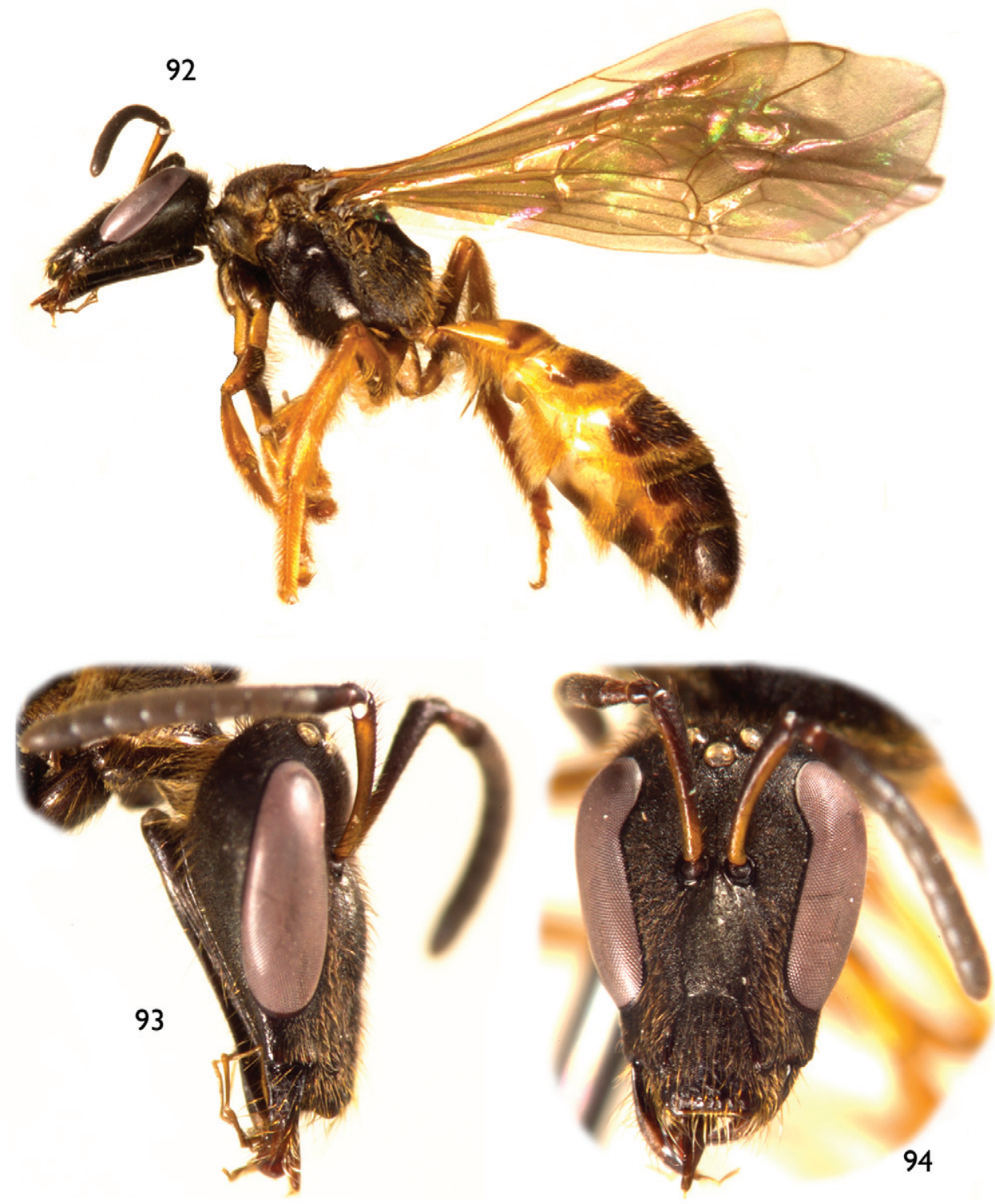

Figures 92-94. Holotype female of Chlerogella mourella Engel. 92 Lateral habitus 93 Lateral aspect of head 94 Facial aspect.

Paratype. Ecuador: 1ㅇ, Napo, Cosanga Aragon, 8 November 1993, G. Onore (QCAZ).

Diagnosis. Chlerogella mourella can be recognized readily by its relatively short malar space and its black head and mesosoma lacking metallic highlights (Figs 92-94).

Description. From Engel (2003b), with minor emendations: Female: Total body length $10.6 \mathrm{~mm}$; forewing length $8.72 \mathrm{~mm}$. Head length $2.44 \mathrm{~mm}$, width $1.84 \mathrm{~mm}$. 
Clypeus beginning just above lower tangent of compound eyes. Malar space 19\% compound eye length (malar length $0.3 \mathrm{~mm}$, compound eye length $1.58 \mathrm{~mm}$ ) (Figs 93-94). Upper interorbital distance $0.96 \mathrm{~mm}$; lower interorbital distance $0.88 \mathrm{~mm}$. Upper portion of pronotum medially depressed, not elongate, medially less than 0.25 times ocellar diameter in length; ventral portion of preëpisternal sulcus not broad, similar to scrobal sulcus and upper portion of preëpisternal sulcus; intertegular distance $1.5 \mathrm{~mm}$; mesoscutellum weakly convex, not bigibbous. Basal vein distad $\mathrm{cu}-\mathrm{a}$ by three times vein width; $1 \mathrm{rs}-\mathrm{m}$ distad $1 \mathrm{~m}$-cu by 3.5 times vein width; $2 \mathrm{rs}-\mathrm{m}$ distad $2 \mathrm{~m}$-cu by five times vein width, 2rs-m straight; first submarginal cell longer than combined lengths of second and third submarginal cells; second submarginal cell slightly narrowed anteriorly, anterior border of second submarginal cell along Rs shorter than that of third submarginal cell; posterior border of third submarginal cell about two times longer than anterior border. Distal hamuli arranged 2-1-2. Inner metatibial spur with six branches (not including apical portion of rachis).

Clypeus and supraclypeal area granular with weak punctures separated by a puncture width; face granular with minute punctures in malar space separated by a puncture width; vertex weakly granular, becoming imbricate on gena and more strongly so by postgena. Pronotum weakly imbricate; mesoscutum granular; mesoscutellum and metanotum finely imbricate with faint punctures. Preëpisternum and mesepisternum granular with faint punctures separated by 2-3 times a puncture width; hypoepimeral area impunctate; metepisternum faintly imbricate. Propodeum strongly imbricate. Metasoma finely imbricate.

Mandible black with reddish apex; labrum and remainder of head black to dark brown. Antenna dark brown except basal one-fifth and inner surface of scape amber. Mesosoma black (Fig. 92); tegula dark brown. Wing membranes lightly infumate; veins amber except $\mathrm{Sc}+\mathrm{R}$ dark brown. Legs amber except dark brown on procoxa, inner surface of profemur, basal half of mesocoxa, inner base of mesofemur, basal threequarters of metacoxa, basal half of inner surface of metafemur. Metasomal TI amber, with dark brown band just beyond midline, band stopping a distance from apical margin equal to its width, apical margin amber; TII dark brown except basal and apical margins amber; TIII dark brown except apical margin amber; TIV-VI dark brown; SI-II amber; SIII amber except medial dark brown patch; SIV dark brown except apical margin yellowish; SV-VI dark brown.

Pubescence golden except somewhat fuscous on TV-VI and SVI. Dense long, branched setae on discs of SI-II.

Male: Unknown.

\section{Chlerogella euprepia Engel, sp. n.}

urn:lsid:zoobank.org:act:E49A396A-4AED-4A0F-B3A9-5E98F23583DE

Figs 95-98, Map 3

Holotype. ㅇ, Ecuador: Napo, 1200 m, km 7.3 Sarayacu-Loreto rd., 20 July 1994, F. Génier, ex: feces trap (SEMC). 


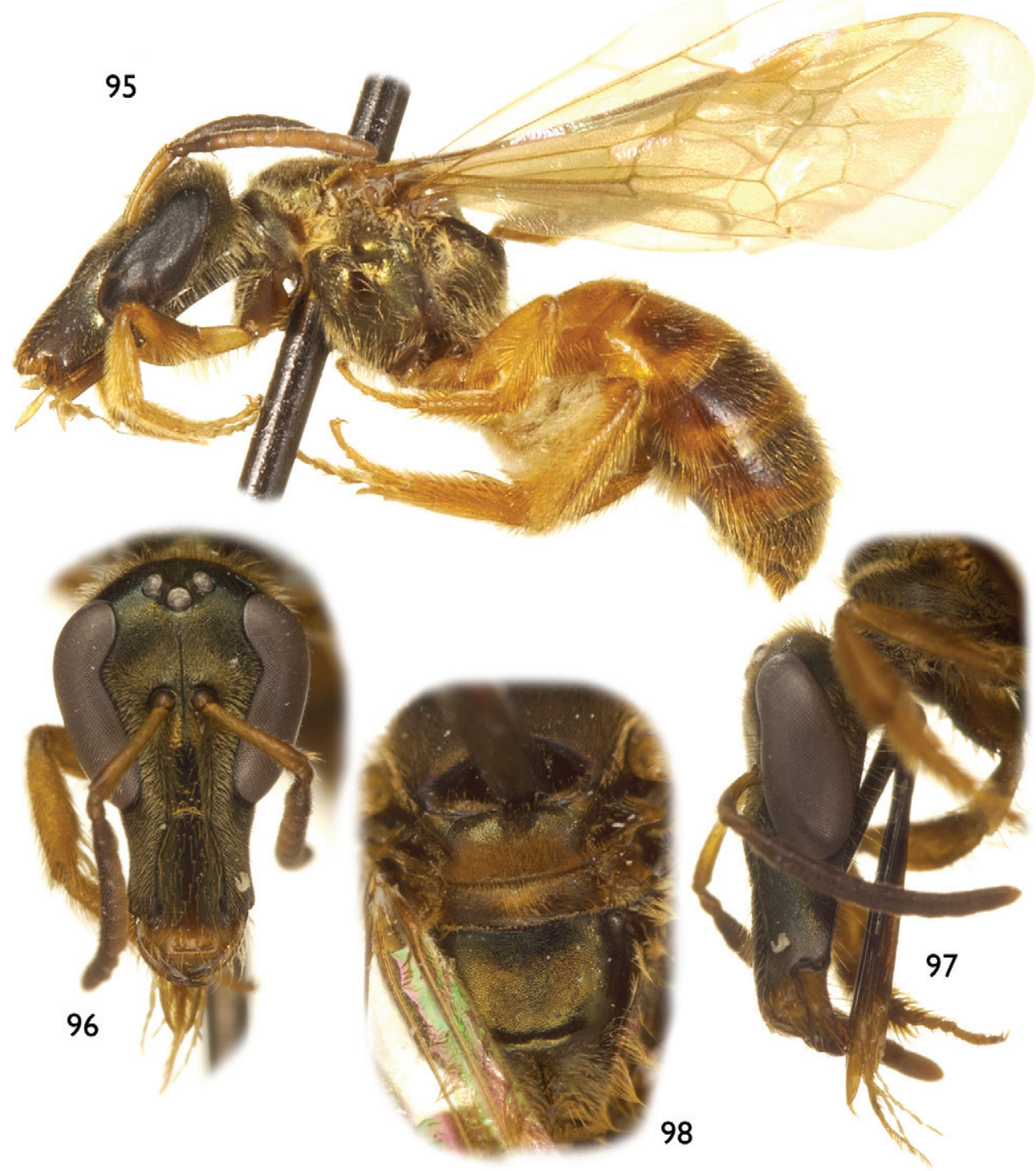

Figures 95-98. Holotype female of Chlerogella euprepia sp. n. 95 Lateral habitus 96 Facial aspect 97 Lateral aspect of head $\mathbf{9 8}$ Dorsal aspect of mesoscutellum, metanotum, and propodeum.

Paratypes. Ecuador: 1 9 , Morona-Santiago, Cord. de Cutucu, $6 \mathrm{~km}$ E of Macas, 1100 m, 9.v.1987 [9 May 1987], M. Cooper (COOP); 1 , Mor. Santiago, Miazal, 50 km SE Macas, 4-7.i.1993 [4-7 January 1993], 300 m, M. \& J. Wasbauer (BLCU); 1우, Napo, via Hollin-Loreto, km 25, 1100 m, 6/12/87 [6 December 1987], leg. M.M. Meria (QCAZ).

Diagnosis. Chlerogella euprepia is noteworthy among longer-headed species of Chlerogella for the amber markings on the mesoscutellum and metanotum, contrasting with the otherwise metallic coloration of the mesosoma (Fig. 98). 
Description. Female: Total body length $9.78-9.82 \mathrm{~mm}$; forewing length $6.47-$ $6.50 \mathrm{~mm}$. Head length $2.69-2.71 \mathrm{~mm}$, width $1.82-1.83 \mathrm{~mm}$. Clypeus beginning below lower tangent of compound eyes. Malar space $44.8-45 \%$ compound eye length (malar length $0.68 \mathrm{~mm}$; compound eye length $1.51-1.52 \mathrm{~mm}$ ) (Figs 96-97). Upper interorbital distance $0.88-0.89 \mathrm{~mm}$; lower interorbital distance $0.65-0.66 \mathrm{~mm}$. Upper portion of pronotum slightly swollen, medially about 1.25 times ocellar diameter in length; ventral portion of preëpisternal sulcus not broad, similar to scrobal sulcus and upper portion of preëpisternal sulcus; intertegular distance $1.32-1.38 \mathrm{~mm}$; mesoscutellum weakly convex, not bigibbous. Basal vein distad cu-a by two times vein width; $1 \mathrm{rs}-\mathrm{m}$ distad $1 \mathrm{~m}$-cu by vein width; $2 \mathrm{rs}-\mathrm{m}$ distad $2 \mathrm{~m}$-cu by four times vein width, 2rs$\mathrm{m}$ straight; first submarginal cell longer than combined lengths of second and third submarginal cells; second submarginal cell slightly narrowed anteriorly, anterior border of second submarginal cell along Rs slightly shorter than that of third submarginal cell; posterior border of third submarginal cell about 1.75 times longer than anterior border. Distal hamuli arranged 2-1-2. Inner metatibial spur with five branches (not including apical portion of rachis).

Clypeus and supraclypeal area smooth with weak punctures separated by $0.5-2$ times a puncture width; face with small contiguous punctures; similar punctures in ocellocular area and vertex, punctures separated by $0.5-1.5$ times a puncture width, integument otherwise finely imbricate; gena finely imbricate with minute punctures separated by a puncture width; postgena imbricate and impunctate. Pronotum imbricate with minute, scattered punctures; mesoscutum imbricate with small punctures separated by less than a puncture width; mesoscutellum as on mesoscutum; metanotum imbricate with scattered minute punctures. Preëpisternum finely imbricate with weak punctures separated by $0.5-2$ times a puncture width; mesepisternum finely imbricate with small and shallow punctures separated by 2-4 times a puncture width; metepisternum finely imbricate. Propodeum strongly imbricate. Metasoma finely imbricate.

Mandible amber except reddish brown at apex; labrum amber; clypeal apex amber, remainder of clypeus and head metallic green with copper highlights. Antenna brown except scape amber and flagellum lighter ventrally. Mesosoma metallic green with copper highlights (Fig. 95) except pronotal lobe brown and mesoscutellum and metanotum largely amber (Fig. 98) and contrasting with mesoscutal and propodeum metallic coloration; tegula translucent amber. Wing membranes yellowed; veins amber except $\mathrm{Sc}+\mathrm{R}$ and longitudinal veins basad basal vein brown. Legs amber except procoxa metallic green. Metasoma amber except TIII-V with large medial, transverse areas of dark brown, similar areas of dark brown on SIII-V (degree of development of such dark brown bands variable in type series).

Pubescence largely golden, somewhat white on face.

Male: Unknown.

Etymology. The specific epithet is based on the Greek term euprepes, meaning "comely". 


\section{Chlerogella elysia Engel, sp. n.}

urn:Isid:zoobank.org:act:953DD3C5-D611-4EB0-9FC3-D88E9B33F67E

Figs 99-106, 115-116, Map 3

Holotype. ㅇ, Ecuador: Pich. [Pichincha], E. Sto. Domingo, 6-12 May 1990, W.J. Hanson (SEMC).

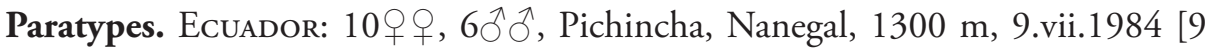
July 1984], M. Cooper (COOP); 4 + , Pichincha, Nanegal, 1300 m, 10.vii.1984 [10 July 1984], M. Cooper (COOP); 10̄, Pichincha, Nanegal, 1300 m, 12.vii.1984 [12 July 1984], M. Cooper (COOP); 1 으, Pinchincha [sic], Rio Palenque Station, $47 \mathrm{~km} \mathrm{S.}$ Sto. [Santo] Domingo, 4.30-5.5 [30 April-5 May] 1987, malaise trap, L. Coote \& B. Brown (YORK); 19, Pichincha, Tinalandia, 15km SE Santo Domingo de los Colorados, vi-29-1982, M. Wasbauer, J. Slansky (BLCU); 1ㅇ, Pich. [Pichincha], E. St. Domingo, 8-14 May 1988, Hanson \& Bohart (BLCU); 10̄, Pich. [Pichincha], nr. Sto. Domingo, 8/14-v-88 [8-14 May 1988], 2500' [2500 feet], Hanson, Bohart (SEMC); $1{ }^{\lambda}$, Bilsa, 10 May-5 June 1996, P. Hibbs, flight intercept trap (SEMC); 1, Pichincha, Maquipucuna Biological Station, river trail, $1200 \mathrm{~m}, 0^{\circ} 7^{\prime} 34^{\prime \prime N}, 78^{\circ} 37^{\prime} 57^{\prime \prime} \mathrm{W}$, 27-29 Oct. [October] 1999, Z.H. Falin, ex: flight intercept trap (SEMC).

Diagnosis. Chlerogella elysia is superficially similar to C. terpsichore but differs most notably in the absence of amber on the clypeus (Fig. 101), the shorter malar space (Figs 100-101, 105-106), presence of distinct fluorescence on the mesosoma and head (Figs 102-103), and male sterna (vide infra) and terminalia (Figs 115-116).

Description. Female: Total body length $8.22-8.39 \mathrm{~mm}$; forewing length $5.93-6.0$ $\mathrm{mm}$. Head length $2.32-2.35 \mathrm{~mm}$, width $1.63-1.72 \mathrm{~mm}$. Clypeus beginning at lower tangent of compound eyes. Malar space 16.4-17.6\% compound eye length (malar length $0.23-0.24 \mathrm{~mm}$; compound eye length $1.46-1.48 \mathrm{~mm}$ ) (Figs 100-101). Upper interorbital distance $0.77-0.81 \mathrm{~mm}$; lower interorbital distance $0.53-0.60 \mathrm{~mm}$. Upper portion of pronotum medially depressed, slightly swollen, medially less than 1.25 times ocellar diameter in length; ventral portion of preëpisternal sulcus not broad, similar to scrobal sulcus and upper portion of preëpisternal sulcus; intertegular distance 1.31-1.41 mm; mesoscutellum weakly convex, not bigibbous. Basal vein distad cu-a by three times vein width; $1 \mathrm{rs}-\mathrm{m}$ distad $1 \mathrm{~m}$-cu by four times vein width; $2 \mathrm{rs}-\mathrm{m}$ distad $2 \mathrm{~m}$-cu by six times vein width, $2 \mathrm{rs}-\mathrm{m}$ arcuate; first submarginal cell longer than combined lengths of second and third submarginal cells; second submarginal cell not narrowed anteriorly, anterior border of second submarginal cell along Rs about as long as third submarginal cell; posterior border of third submarginal cell about two times longer than anterior border. Distal hamuli arranged 2-1-2. Inner metatibial spur with $4-5$ branches (not including apical portion of rachis).

Clypeus and supraclypeal area smooth with weak punctures separated by $1.5-4$ times width; face above level of antennae with small punctures separated by $0.1-1.75$ times a puncture width, below level of antennae and in malar space smooth with punctures separated by width or less; vertex, ocellocular area, and gena smooth with punctures becoming smaller and separated 1-3 times a puncture width; postgena im- 


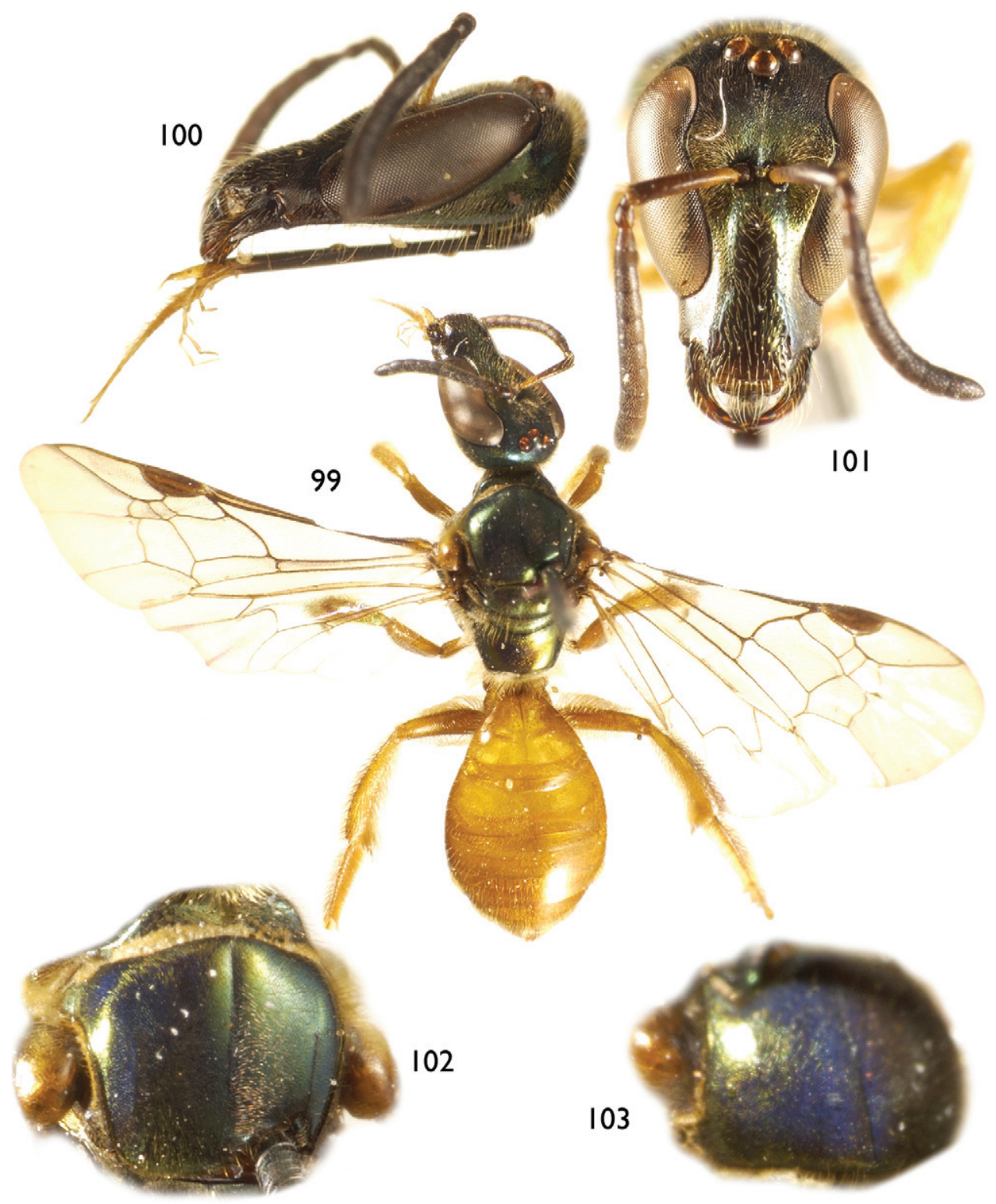

Figures 99-103. Female of Chlerogella elysia sp. n. 99 Dorsal habitus 100 Lateral aspect of head I 0 I Facial aspect $\mathbf{0 2}$ Dorsal aspect of mesoscutum showing fluorescence $\mathbf{0 3}$ Oblique view of mesoscutum showing strong fluorescence.

bricate and impunctate. Pronotum faintly imbricate with scattered minute punctures; mesoscutum smooth with small punctures separated by $1-4$ times a puncture width, punctures weaker anteriorly and integument becoming faintly imbricate; mesoscutellum smooth with punctures separated by $1-2.5$ times a puncture width; metanotum as on mesoscutum. Preëpisternum and mesepisternum smooth with weak punctures sep- 


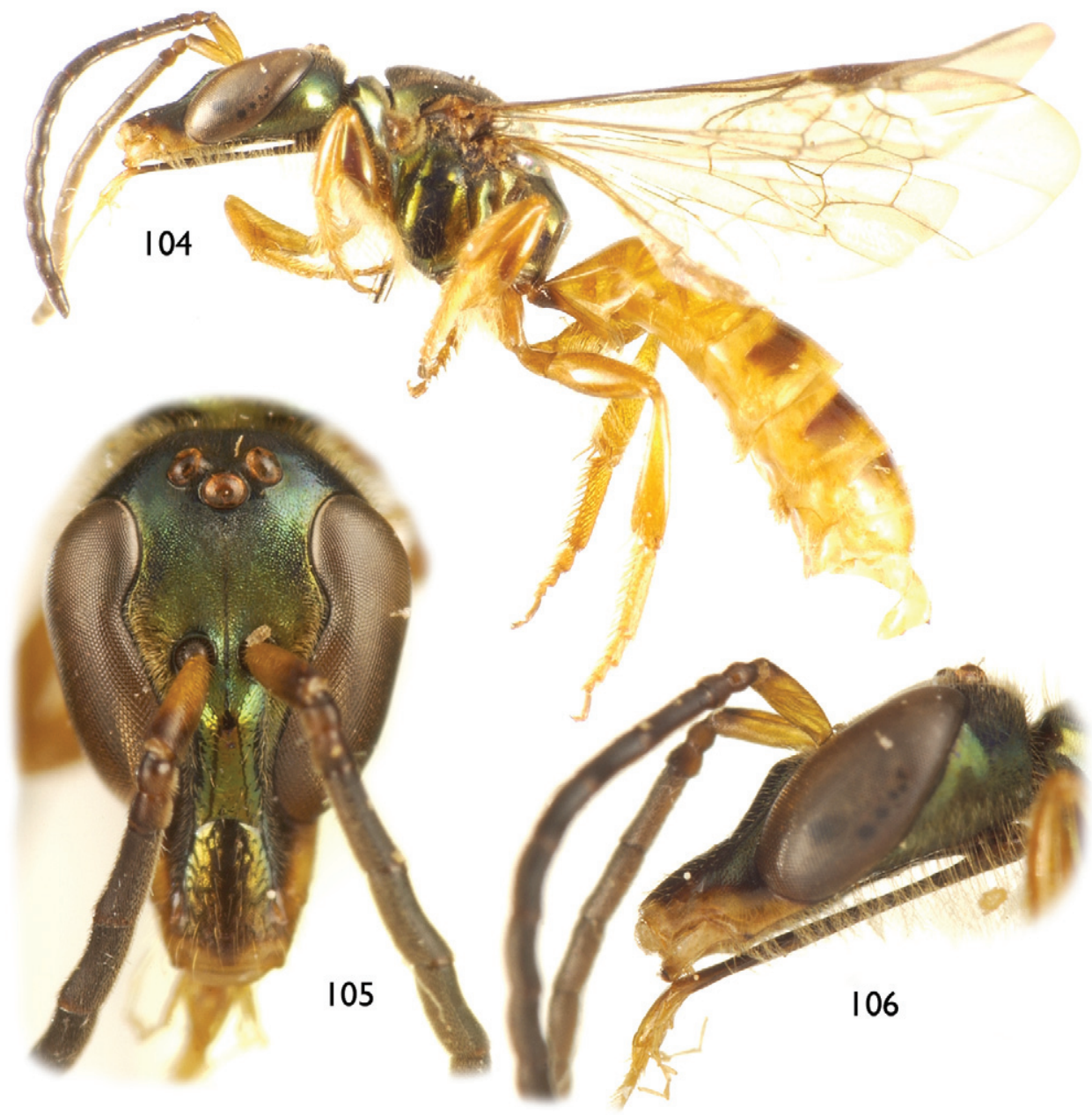

Figures 104-106. Male of Chlerogella elysia sp. n. 104 Lateral habitus 105 Facial aspect 106 Lateral aspect of head.

arated by 2-6 times a puncture width; metepisternum smooth with scattered minute punctures. Propodeum imbricate. Metasoma faintly imbricate.

Mandible dark brown with reddish apex; labrum dark brown; malar space, clypeus, and lower two-thirds supraclypeal area dark brown with weak copper highlights; basal area and lateral borders of supraclypeal area and remainder of head dark metallic green with copper highlights and blue fluorescence (giving a blue-green cast to some specimens). Antenna brown except basal half of scape amber. Mesosoma dark metallic green with copper-gold highlights and strong overlaying blue fluorescence on mesoscutum (Figs 102-103) (opalescence present but weaker on mesoscutellum, metanotum, and propodeum); pronotal lobe amber; tegula amber. Wings hyaline; veins brown. Legs amber except procoxa dark metallic green and in some specimens areas of brown on 
inner surfaces of coxae, trochanters, femora, and tibiae. Metasoma amber (Fig. 99) except some specimens marked with brown on basal thirds of TIII-VI and SIII-VI (rarely with a very thin light brown transverse band on TII).

Pubescence golden.

Male: As described for the female except as follows: Total body length 9.15-9.30 $\mathrm{mm}$; forewing length $5.87-6.13 \mathrm{~mm}$. Head length $2.30-2.48 \mathrm{~mm}$, width $1.59-1.63$ $\mathrm{mm}$. Clypeus beginning at lower tangent of compound eyes. Malar space 18-19.9\% compound eye length (malar length 0.26-0.29 mm; compound eye length 1.44-1.46 $\mathrm{mm}$ ) (Figs 105-106). Upper interorbital distance 0.73-0.74 mm; lower interorbital distance $0.39-0.40 \mathrm{~mm}$. First flagellomere about as long as pedicel, about as long as wide; second flagellomere 2.4 times length of first flagellomere; ventral surfaces of second through eleventh flagellomeres densely covered in placoid sensilla, placoid fields not disrupted. Intertegular distance $1.22-1.25 \mathrm{~mm}$; mesoscutellum not bigibbous. Inner metatibial spur serrate. Apical margin of SIII entire; apical margin of SIV broadly concave between broad paramedial lobes, without furrow in apical half of disc; apical margin of SV entire; apical margin of SVI emarginate; terminalia as depicted in figures 115 and 116.

Mandible and labrum yellow in coloration; clypeal apex and most of malar space amber, remainder of clypeus largely dark brown with strong metallic copper highlights except with overlaying metallic green basally; supraclypeal area dark metallic green with copper highlights. Scape amber on basal two-thirds to three-quarters.

Typical gender pilosity except postgena with scattered elongate, sinuate setae, such setae with short apical branches; inner surfaces of procoxa, trochanters, profemur, mesofemur, and metacoxa with elongate, apically-plumose setae (such setae particularly numerous on procoxa, protrochanter, and base of profemur), similar setae on inner surfaces of metatrochanter, metafemur, and metatibia except largely simple and somewhat sinuate. Apical margin of SIII with fringe of moderate-length golden setae; SIV with patches of short, subappressed dense golden fuscous setae bordering medial emargination and extending posteriorly along disc; SV laterally with diffuse areas of long, inwardly-curved setae.

Etymology. The specific epithet is taken from the Latin Elysium, abode of the blessed, and is a reference to the unearthly fluorescence of this beautiful species.

\section{Chlerogella hypermeces Engel, sp. n.}

urn:lsid:zoobank.org:act:0D852549-8937-41FB-B786-F1E401AF1905

Figs 107-114, 117-118, Maps 3, 4

Holotype. + , Ecuador: Morona-Santiago, Cord. de Cutucu, 6 km E. of Macas, 1100 m, 14.v.1987 [14 May 1987], M. Cooper (COOP).

Paratypes. Ecuador: $19,1 \mathrm{O}^{\lambda}$, same data as holotype (COOP); 19 , MoronaSantiago, Cord. de Cutucu, 6 km E. of Macas, 1100 m, 14.v.1987 [25 May 1987], M. Cooper (COOP); 1 , , Morona-Santiago, Cord. de Cutucu, 6 km E. of Macas, 1100 


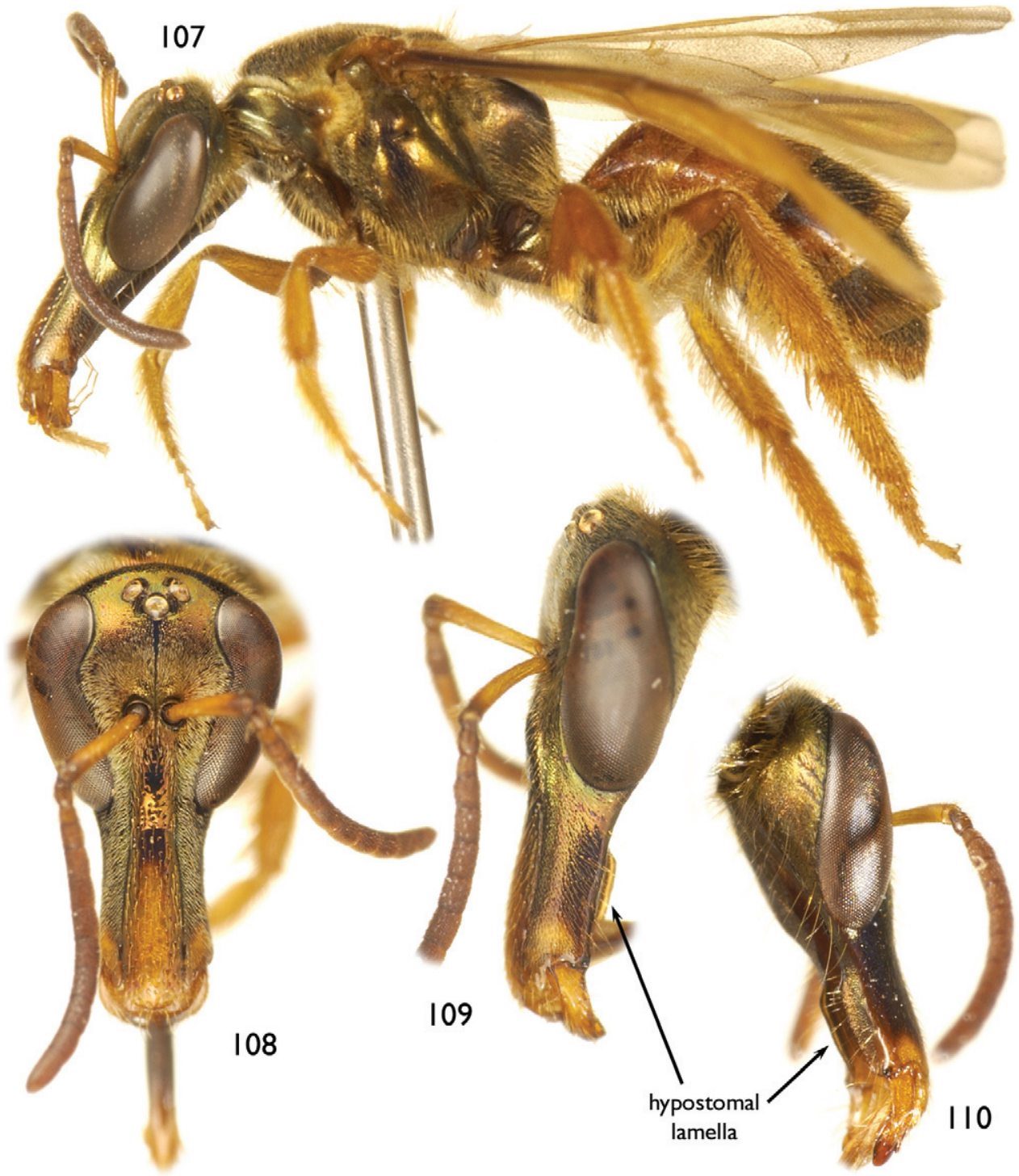

Figures I 07-I I 0. Female of Chlerogella hypermeces sp. n. 107 Lateral habitus 108 Facial aspect I 09 Lateral aspect of head $\mathbf{I} \mathbf{I} 0$ Oblique ventrolateral aspect of head, detailing anterior hypostomal lamella.

m, 26.vi.1981 [26 June 1981], M. Cooper (COOP); 19, Morona-Santiago, Cord. de Cutucu, 6 km E. of Macas, 1100 m, 9.v.1987 [9 May 1987], M. Cooper (COOP); 1오, Morona-Santiago, Cord. de Cutucu, 6 km E. of Macas, 1000 m, 31.i.1991 [31 January 1991], M. Cooper (COOP); 19, Morona-Santiago, Cord. de Cutucu, 6 km E. of Macas, 1000 m, 31.v.1990 [31 May 1990], M. Cooper (COOP); 10, MoronaSantiago, Cord. de Cutucu, 6 km E. of Macas, 1100 m, 21.v.1981 [21 May 1981], M. Cooper (COOP); 10̄, Morona-Santiago, Macas, 1100 m, 5.ii.1982 [5 February 


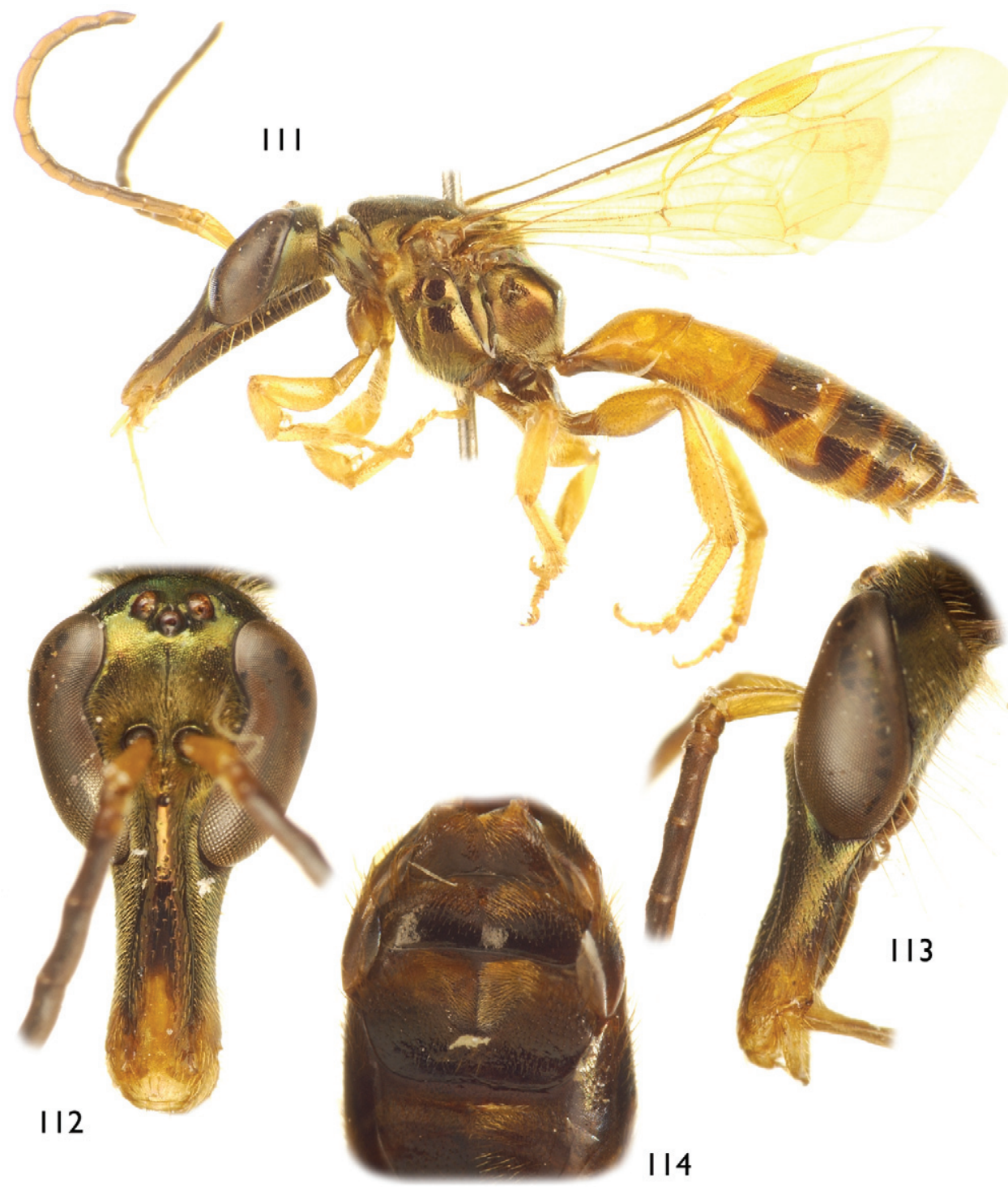

Figures I I I-I I 4. Male of Chlerogella hypermeces sp. n. I I I Lateral habitus I I 2 Facial aspect I I 3 Lateral aspect of head I I 4 Apical metasomal sterna.

1982], M. Cooper (COOP); 10 , Morona-Santiago, Cord. de Cutucu, 6 km E. of Macas, 1100 m, 16.v.1987 [16 May 1987], M. Cooper (COOP); 1ठ, Morona-Santiago, Cord. de Cutucu, 6 km E. of Macas, 1100 m, 26.iii.1981 [26 March 1981], M. Cooper (COOP); 1ㅇ, 1才, Morona-Santiago, Cord. de Cutucu, $6 \mathrm{~km}$ E. of Macas, $1100 \mathrm{~m}$, 25.v.1987 [25 May 1987], M. Cooper (COOP); 1, Morona-Santiago, Rio Upano, $6 \mathrm{~km}$ East of Sucua, $750 \mathrm{~m}$, 16.vii.1984, M. Cooper (COOP). Colombia: $2 \widehat{\jmath}$, Putumayo, Villa Garzon, 400-550 m, 25.xii.1987 [25 December 1987], M. Coop- 


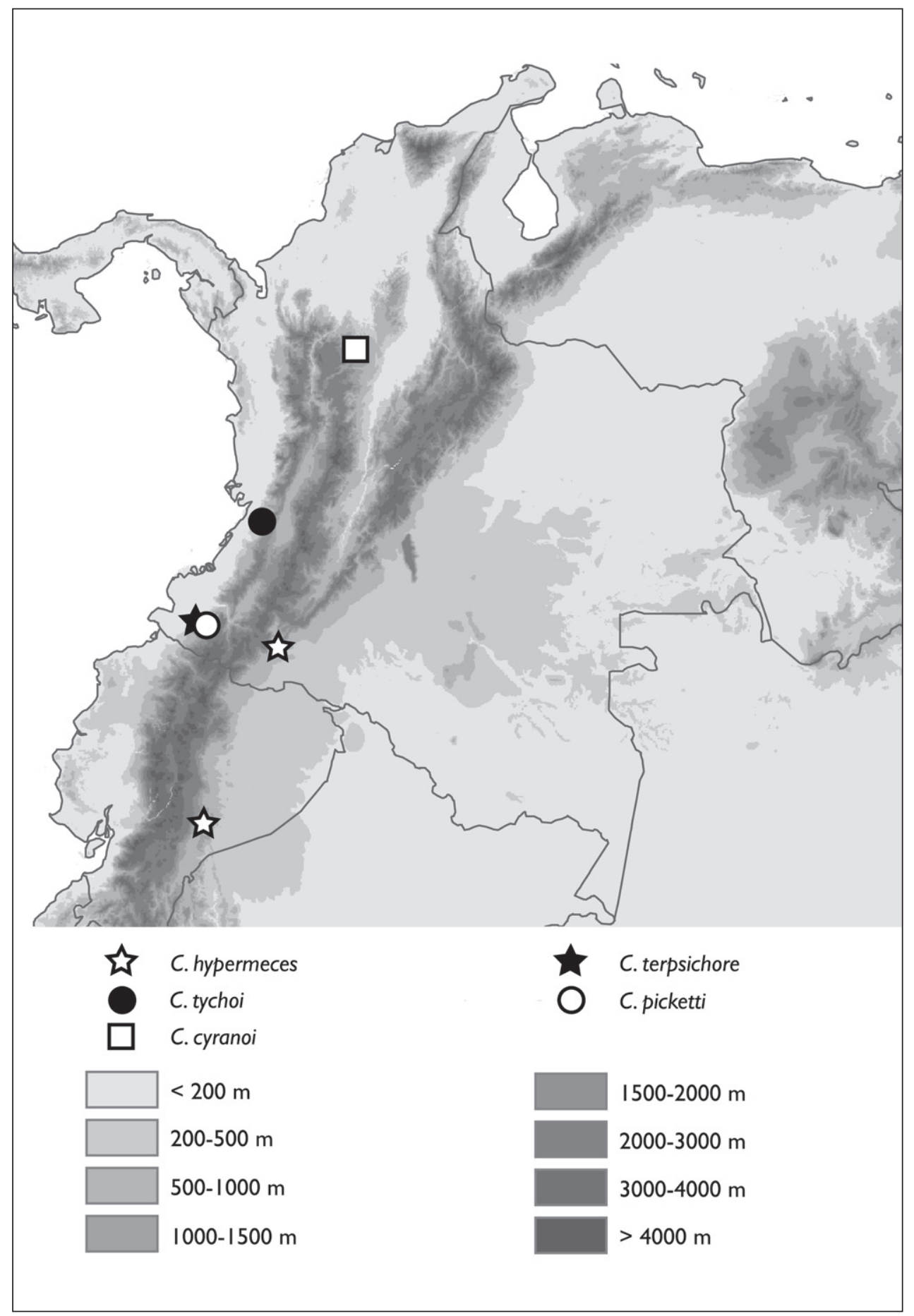

Map 4. Collection localities for Colombian Chlerogella (note that $C$. hypermeces extends into Ecuador; vide etiam Map 3). 

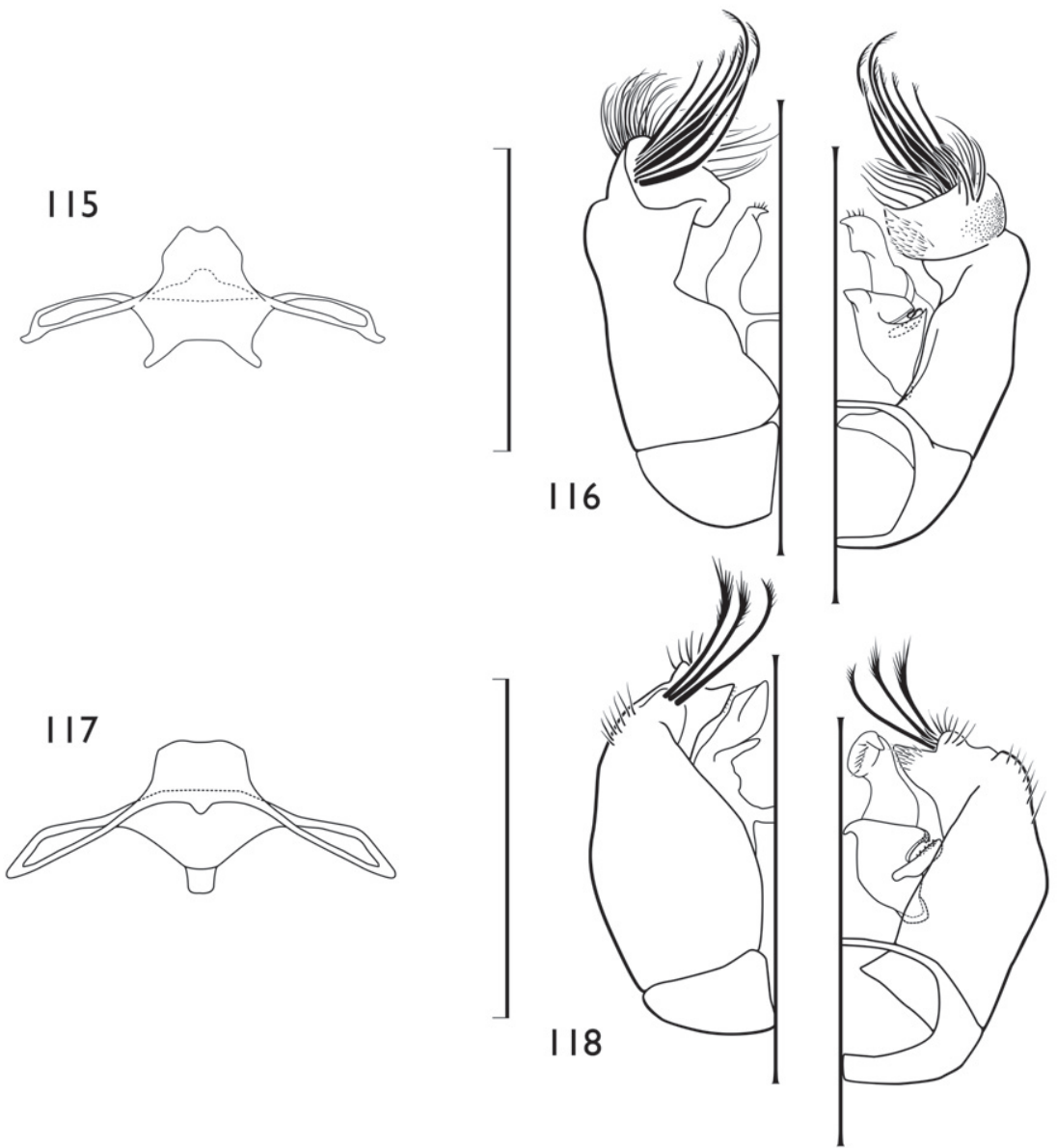

Figures I I5-I I 8. Male terminalia for some Ecuadorian Chlerogella species (note: C. hypermeces sp. n., also has been recorded from southern Colombia, vide Map 4). I I 5 Chlerogella elysia sp. n., hidden and fused sterna VII and VIII II 6 C. elysia sp. n., genital capsule (left is dorsal aspect, right is ventral aspect) II 7 C. hypermeces sp. n., hidden and fused sterna VII and VIII II 8 C. hypermeces sp. n., genital capsule (left is dorsal aspect, right is ventral aspect). All scale bars $=1 \mathrm{~mm}$.

er (COOP); 10, Putumayo, Villa Garzon, 400-550 m, 24.xii.1987 [24 December 1987], M. Cooper, on flowers of Palicourea pongoana Standl. [this is actually Psychotria pongoana] (Rubiaceae) (COOP); 1 9 , Putumayo, Villa Garzon, 400 m, 13.x.1984 [13 October 1984], M. Cooper (COOP).

Diagnosis. This is one of the largest species of the genus, resembling in size $C$. hauseri from Bolivia (vide supra) and, also like $C$. hauseri, has one of the most elongate heads (Table 2). Females of $C$. hypermeces are immediately recognizable owing to the large hypostomal lamellae formed on the rostrum (Figs 109-110). While males lack this feature (or have it only very weakly developed), their coloration (Figs 111-113), sternal structure (Fig. 114), and terminalia (Figs 117-118) are immediately distinc- 
tive. Female coloration, which is similar to the male, also serves to separate them from congeners (Figs 107-110).

Description. Female: Total body length 9.81-9.90 mm; forewing length 6.80$6.93 \mathrm{~mm}$. Head length 3.07-3.23 mm, width 1.80-1.88 mm. Hypostomal carina enlarged into enlarged lamella in anterior half of head near mandibular base (Figs. 109-110). Clypeus beginning below lower tangent of compound eyes. Malar space 65.2-66\% compound eye length (malar length 1.03-1.07 mm; compound eye length 1.57-1.64 mm) (Figs 108-110). Upper interorbital distance 0.86-0.90 mm; lower interorbital distance $0.57-0.63 \mathrm{~mm}$. Upper portion of pronotum medially depressed, slightly elongate, medially less than 0.75 times ocellar diameter in length; ventral portion of preëpisternal sulcus not broad, similar to scrobal sulcus and upper portion of preëpisternal sulcus; intertegular distance $1.41-1.48 \mathrm{~mm}$; mesoscutellum weakly convex, not bigibbous. Basal vein distad cu-a by three times vein width; $1 \mathrm{rs}-\mathrm{m}$ distad $1 \mathrm{~m}-\mathrm{cu}$ by two times vein width; 2 rs-m distad $2 \mathrm{~m}$-cu by six times vein width, 2rs-m gently arched; first submarginal cell longer than combined lengths of second and third submarginal cells; second submarginal cell narrowed anteriorly, anterior border of second submarginal cell along Rs slightly shorter than that of third submarginal cell; posterior border of third submarginal cell about two times longer than anterior border. Distal hamuli arranged 2-1-2. Inner metatibial spur with 5-6 branches (not including apical portion of rachis).

Clypeus and supraclypeal area faintly imbricate with weak punctures separated by 1-3.5 times a puncture width; face above level of antennae minutely punctured, punctures separated by less than a puncture width and frequently nearly contiguous, below level of antennae and in malar space punctures slightly more widely spaced; punctures of face blending to smooth integument in ocellocular area and vertex, with smaller punctures separated by 1-2.5 times a puncture width; gena smooth with minute punctures separated by $1-3$ times a puncture width; postgena imbricate and impunctate. Pronotum faintly imbricate with scattered minute punctures; mesoscutum smooth with small punctures separated by $0.5-1.5$ times a puncture width, puntures weaker anteriorly, blending to imbricate integument anteromedially; mesoscutellum smooth with small punctures separated by $0.5-1.5$ times a puncture width; metanotum faintly imbricate with minute punctures separated by $0.5-2$ times a puncture width. Preëpisternum smooth with small punctures separated by 0.5-2 times a puncture width; mesepisternum smooth with weak punctures separated by 2-6 times a puncture width; metepisternum faintly imbricate. Propodeum strongly imbricate. Metasoma faintly imbricate.

Mandible amber except reddish at apex; labrum amber; clypeal apex and medially for most of surface amber, basal borders of clypeus dark brown with strong metallic copper highlights; malar space with amber patch near mandibular base otherwise dark brown with strong metallic copper and sometimes green highlights; supraclypeal area dark brown with strong metallic copper highlights; remainder of head metallic copper-green. Antenna light brown except scape amber. Mesosoma metallic copper green (Fig. 107); tegula amber. Wing membranes lightly infumate or yellowed; veins amber except Sc+R brown. Legs 
amber except coxae, trochanters, and proximal half of metafemur brown with copper green highlights. Metasoma amber except TIII to metasomal apex dark brown with strong metallic copper highlights and translucent amber apical margins; sterna dark brown.

Pubescence golden except slightly more fuscous apically on metasoma.

Male: As described for the female except as follows: Total body length 10.88$11.70 \mathrm{~mm}$; forewing length $6.80-7.0 \mathrm{~mm}$. Head length $3.15-3.30 \mathrm{~mm}$, width $1.63-1.83 \mathrm{~mm}$. Hypostomal carina not lamellate or only very weakly so anteriorly. Clypeus beginning below lower tangent of compound eyes. Malar space 69.5-70\% compound eye length (malar length 1.07-1.10 mm; compound eye length 1.54-1.58 $\mathrm{mm}$ ) (Figs. 112-113). Upper interorbital distance $0.78-0.83 \mathrm{~mm}$; lower interorbital distance $0.42-0.50 \mathrm{~mm}$. First flagellomere about as long as pedicel, about as long as wide; second flagellomere 3.4 times length of first flagellomere; ventral surfaces of second through eleventh flagellomeres densely covered in placoid sensilla, placoid fields not disrupted. Intertegular distance $1.39-1.50 \mathrm{~mm}$; mesoscutellum not bigibbous, faintly depressed medially. Inner metatibial spur serrate. Apical margin of SIII entire; apical margin of SIV weakly emarginate, margin weakly and broadly produced lateral to emargination, without furrow in apical half of disc (Fig. 114); apical margin of SV entire; apical margin of SVI emarginate; terminalia as depicted in figures 117 and 118 .

Mandible and labrum more yellow in coloration; amber mark on clypeus typically extending from apex to only about midlength of clypeus, remainder dark brown with strong metallic copper highlights. Legs typically more yellow than in female. Metasoma with amber in basal third on TIII-V in some males.

Typical gender pilosity except postgena with scattered elongate, sinuate setae, such setae with short apical branches; inner surfaces of trochanters, profemur, mesofemur, and metacoxa with elongate, apically-plumose setae (such setae particularly numerous on protrochanter and base of profemur), similar setae on inner surfaces of metatrochanter, metafemur, and metatibia except largely simple and somewhat sinuate. Apical margin of SIII with fringe of moderate-length golden setae; SIV with small, apicolateral areas of diffuse long golden setae and patches of short, subappressed dense setae bordering medial emargination and extending posteriorly along disc; SV laterally with diffuse areas of long, inwardly-curved setae.

Etymology. The specific epithet is taken from the Greek term hypermekes, meaning "very long".

Floral record. A male of C. hypermeces was captured at flowers of Psychotria pongoana Standl. (Rubiaceae) in Putumayo, Colombia.

\section{Chlerogella terpsichore Engel, sp. n.}

urn:Isid:zoobank.org:act:DBD887A9-2384-499B-8FD5-B3CDF3DCFA3F

Figs 119-125, 135-136, Map 4

Holotype. +, Colombia: Nariño, Barbacoas, 40 m, 2.x.1990 [2 October 1990], M. Cooper (COOP). 


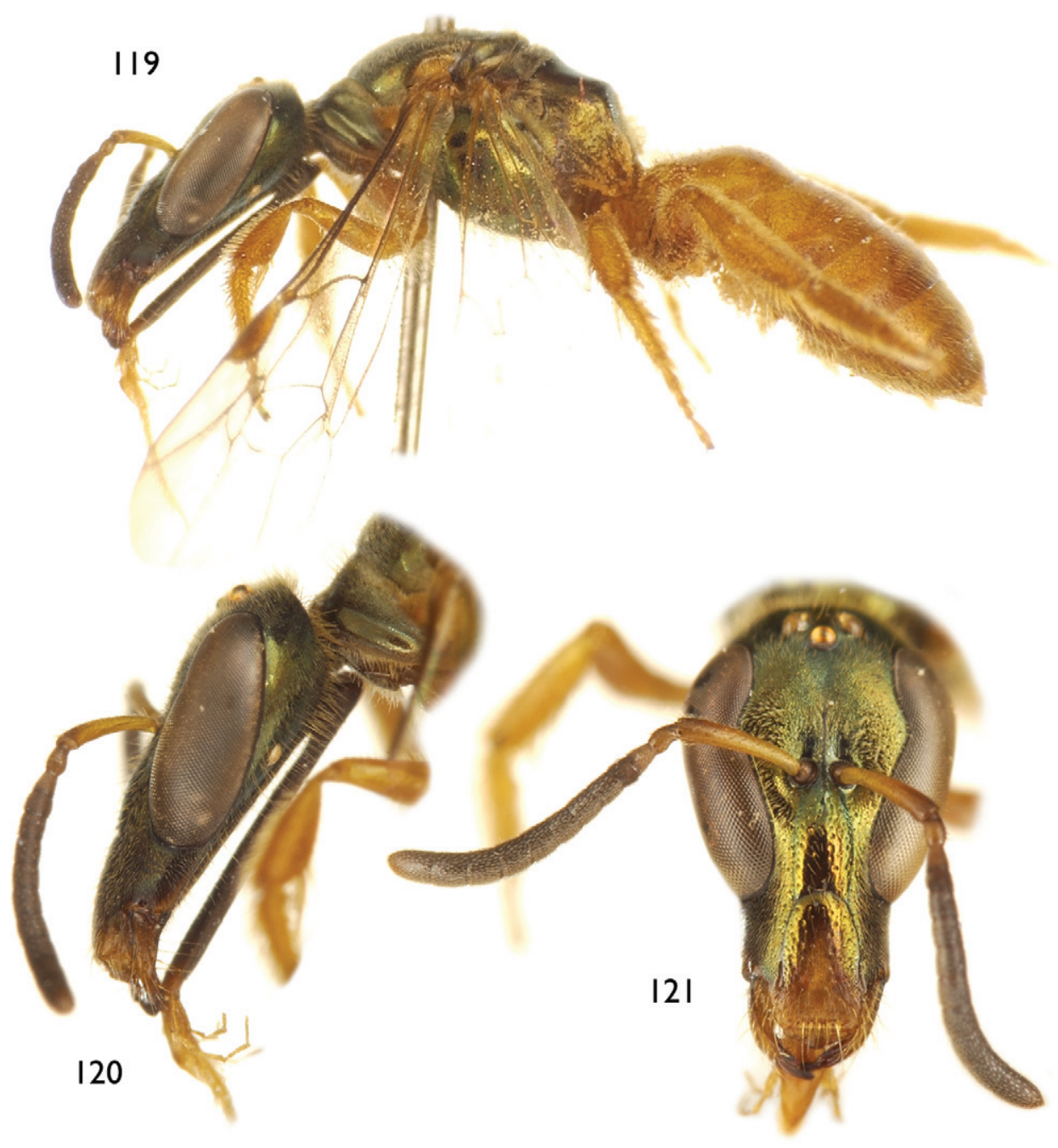

Figures I I 9-I 2 I. Female of Chlerogella terpsichore sp. n. I I 9 Lateral habitus I 20 Lateral aspect of head I 2 I Facial aspect.

Paratypes. Colombia: $4 \widehat{\jmath} \widehat{\jmath}$, Nariño, Barbacoas, 40 m, 1.x.1990 [1 October 1990], M. Cooper (COOP); 1옹 Nariño, Barbacoas, 40 m, 2.x.1990 [2 October 1990], M. Cooper (COOP); 1 + , Narińo, Barbacoas, 40 m, 3.x.1990 [3 October 1990], M. Cooper (COOP); 10ิ, 1ㅇ, Nariño, Barbacoas, 40 m, 4.x.1990 [4 October 1990], M. Cooper (COOP).

Diagnosis. Chlerogella terpsichore is most superficially similar to C. elysia but differs in the presence of amber on the clypeus and the absence of distinct fluorescence on the mesosoma and head. In structural features, C. terpsichore is similar to C. elongaticeps from Panama in the presence of lateral processes on SIV (Fig. 125), a unique feature 


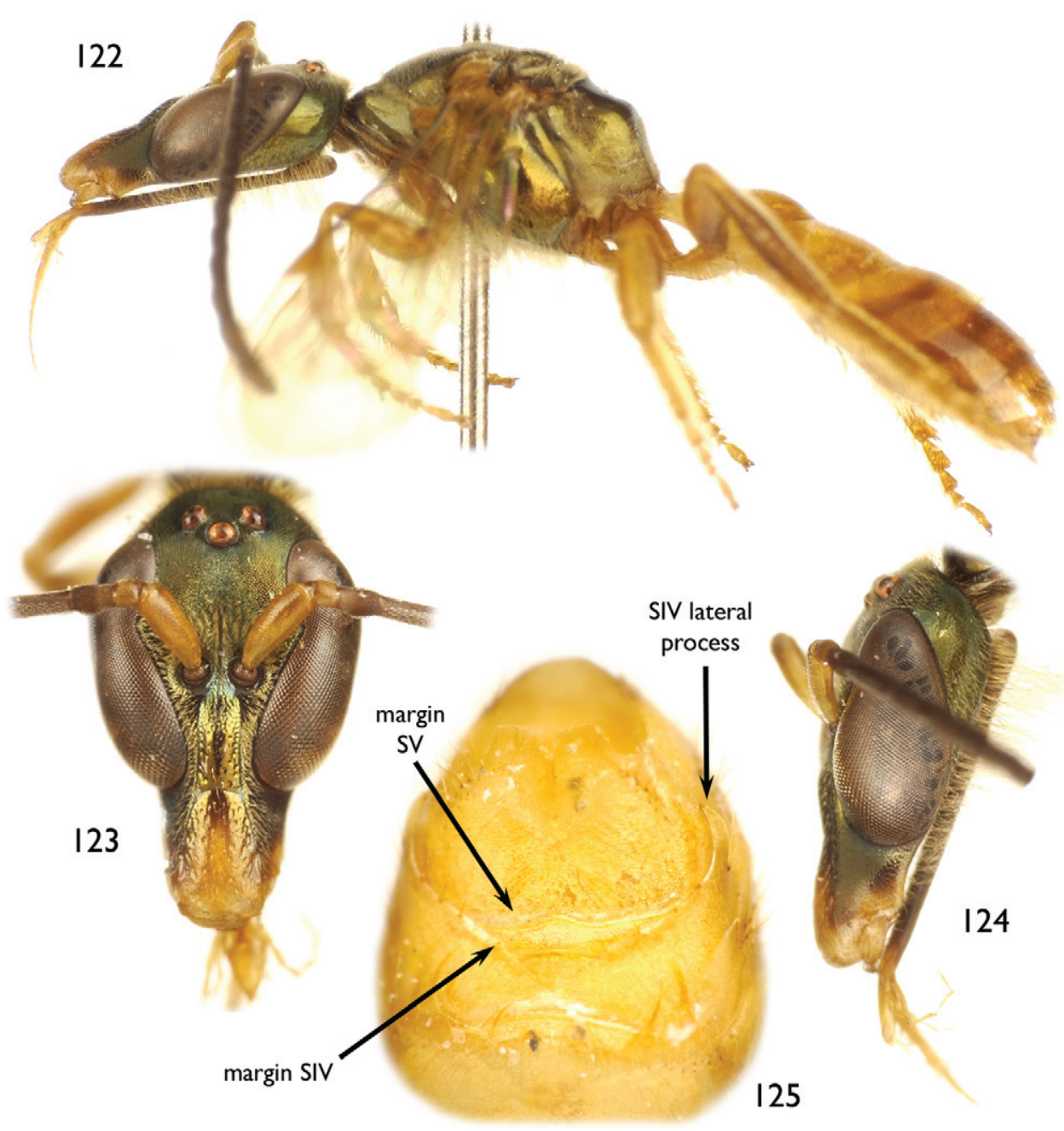

Figures I 22-1 25. Male of Chlerogella terpsichore sp. n. I 22 Lateral habitus I 23 Facial aspect I 24 Lateral aspect of head $\mathbf{I} \mathbf{2 5}$ Apical metasomal sterna.

among the South American species of the genus. The species is also similar to C. tychoi, also from Colombia, but has a shorter malar space (Figs 120-121) and different structure to the inner metatibial spur.

Description. Female: Total body length $8.22-8.30 \mathrm{~mm}$; forewing length $5.07-$ $5.12 \mathrm{~mm}$. Head length $2.35-2.36 \mathrm{~mm}$, width $1.55-1.57 \mathrm{~mm}$. Clypeus beginning at or minutely below lower tangent of compound eyes. Malar space $30.9-31.1 \% \mathrm{com}$ pound eye length (malar length $0.43-0.44 \mathrm{~mm}$; compound eye length $1.39-1.41 \mathrm{~mm}$ ) (Figs 120-121). Upper interorbital distance $0.77-0.78 \mathrm{~mm}$; lower interorbital distance $0.51-0.53 \mathrm{~mm}$. Upper portion of pronotum slightly swollen, medially about 1.25 times ocellar diameter in length; ventral portion of preëpisternal sulcus not broad, 
similar to scrobal sulcus and upper portion of preëpisternal sulcus; intertegular distance 1.15-1.19 mm; mesoscutellum weakly convex, not bigibbous. Basal vein distad $\mathrm{cu}-\mathrm{a}$ by three times vein width; $1 \mathrm{rs}-\mathrm{m}$ distad $1 \mathrm{~m}$-cu by five times vein width; $2 \mathrm{rs}-\mathrm{m}$ distad $2 \mathrm{~m}$-cu by seven times vein width, 2rs-m straight; first submarginal cell longer than combined lengths of second and third submarginal cells; second submarginal cell narrowed anteriorly, anterior border of second submarginal cell along Rs about onehalf as along as that of third submarginal cell; posterior border of third submarginal cell about 1.75 times longer than anterior border. Distal hamuli arranged 2-1-2. Inner metatibial spur with five branches (not including apical portion of rachis).

Clypeus and supraclypeal area smooth with weak punctures separated by $0.5-2$ times a puncture width; face with small punctures separated by a puncture width or less; similar punctures and integument in ocellocular area and vertex, punctures separated by $1-1.5$ times a puncture width; gena smooth with minute punctures separated by 1-4 times a puncture width; postgena imbricate and impunctate. Pronotum faintly imbricate with minute, scattered punctures; mesoscutum smooth with small punctures separated by a puncture width or less; mesoscutellum smooth with minute punctures separated by a puncture width; metanotum faintly imbricate with minute punctures separated by 2-3 times a puncture width. Preëpisternum weakly rugulose above blending to weakly imbricate with shallow, coarse punctures separated by a puncture width or less; mesepisternum smooth, with small and shallow punctures separated by 1-3 times a puncture width; metepisternum faintly imbricate. Propodeum strongly imbricate. Metasoma finely imbricate.

Mandible amber except reddish brown at apex; labrum amber; clypeal apex and central area amber, blending to amber brown and brilliant metallic green with strong copper highlights, supraclypeal area brilliant metallic green with strong copper highlights, remainder of head brilliant metallic green with varying copper highlights, green and highlights less strong in malar space. Antenna dark brown except basal two-thirds of scape amber, pedicel and first flagellomere amber brown. Mesosoma brilliant metallic green with copper highlights except pronotal lobe amber (Fig. 119); tegula translucent amber. Wing membranes hyaline; veins brown except $\mathrm{C}$ and $\mathrm{Sc}+\mathrm{R}$ dark brown. Legs amber. Metasoma amber.

Pubescence white and golden.

Male: As described for the female except as follows: Total body length 8.50-8.64 $\mathrm{mm}$; forewing length $5.13-5.22 \mathrm{~mm}$. Head length $2.37-2.41 \mathrm{~mm}$, width $1.57-1.60$ mm. Malar space 30.5-31.0\% compound eye length (malar length $0.43-0.44 \mathrm{~mm}$; compound eye length 1.41-1.42 mm) (Figs 123-124). Upper interorbital distance $0.75-0.77 \mathrm{~mm}$; lower interorbital distance $0.37-0.38 \mathrm{~mm}$. First flagellomere about 1.75 times longer than wide, longer than pedicel; second flagellomere two times length of first flagellomere; ventral surfaces of second through eleventh flagellomeres densely covered in placoid sensilla, placoid fields not disrupted. Intertegular distance 1.07$1.15 \mathrm{~mm}$. Inner metatibial spur serrate. Apical margin of SIII weakly concave; apical margin of SIV deeply concave, almost V-shaped, laterally produced into long processes (Fig. 125), without medio-longitudinal furrow on disc; apical margin of SV relatively 
entire, with exceedingly faint hump medially; apical margin of SVI emarginate; terminalia as depicted in figures 135 and 136.

Scape and pedicel amber, remainder of antenna brown. Metasoma sometimes with more apical terga (beyond TII) marked with light brown to brown, otherwise entirely amber.

Typical gender pilosity except postgena with numerous elongate, sinuate setae, such setae with short apical branches; inner surfaces of trochanters, mesofemur, and metacoxa with elongate, apically-plumose setae, similar setae on inner surfaces of metatrochanter and metafemur; metatibia without distinctly elongate and sinuous setae. Apical margin of SIII with lateral areas of long, diffuse apical setae; SIV with patch of small darker setae at apices of lateral processes, with three long setae positioned along lateral thirds of margins and before lateral processes; SV with scattered setae.

Etymology. The specific epithet is from the Greek muse for dance, Terpsichore.

\section{Chlerogella picketti Engel, sp. n.}

urn:lsid:zoobank.org:act:AB78C966-2C49-4C2B-BB77-787024DBECFB

Figs 126-128, 137-138, Map 4

Holotype. ${ }^{\lambda}$, Colombia: Nariño, Barbacoas, 40 m, 1.x.1990 [1 October 1990], M. Cooper (COOP).

Diagnosis. Among relatively short-faced species of Chlerogella, C. picketti is distinctive for its metallic green coloration (Figs 126-128), setation of the metafemur (vide infra), and male terminalia (Figs 137-138).

Description. Male: Total body length $8.09 \mathrm{~mm}$; forewing length $5.33 \mathrm{~mm}$. Head length $2.16 \mathrm{~mm}$, width $1.56 \mathrm{~mm}$. Clypeus beginning above lower tangent of compound eyes. Malar space $18.8 \%$ compound eye length (malar length $0.26 \mathrm{~mm}$; compound eye length $1.38 \mathrm{~mm}$ ) (Figs 127-128). Upper interorbital distance 0.70 $\mathrm{mm}$; lower interorbital distance $0.39 \mathrm{~mm}$. First flagellomere about as long as pedicel, about as long as wide; second flagellomere three times length of first flagellomere; ventral surfaces of second through eleventh flagellomeres densely covered in placoid sensilla, placoid fields not disrupted. Upper portion of pronotum medially depressed, not elongate, medially less than 0.25 times ocellar diameter in length; ventral portion of preëpisternal sulcus not broad, similar to scrobal sulcus and upper portion of preëpisternal sulcus; intertegular distance $1.17 \mathrm{~mm}$; mesoscutellum weakly bigibbous. Basal vein distad cu-a by three times vein width; $1 \mathrm{rs}-\mathrm{m}$ distad $1 \mathrm{~m}$-cu by four times vein width; 2 rs-m distad $2 \mathrm{~m}-\mathrm{cu}$ by six times vein width, $2 \mathrm{rs}-\mathrm{m}$ straight; first submarginal cell longer than combined lengths of second and third submarginal cells; second submarginal cell slightly narrowed anteriorly, anterior border of second submarginal cell along Rs about 0.8 times as along as that of third submarginal cell; posterior border of third submarginal cell about 2.5 times as long as anterior border. Distal hamuli arranged 2-1-2. Inner metatibial spur minutely ciliate. Apical margin of SIII entire; apical margin of SIV broadly and weakly concave medially, produced lateral to concavity as short broad setose lobes, without furrow in apical half of disc; 


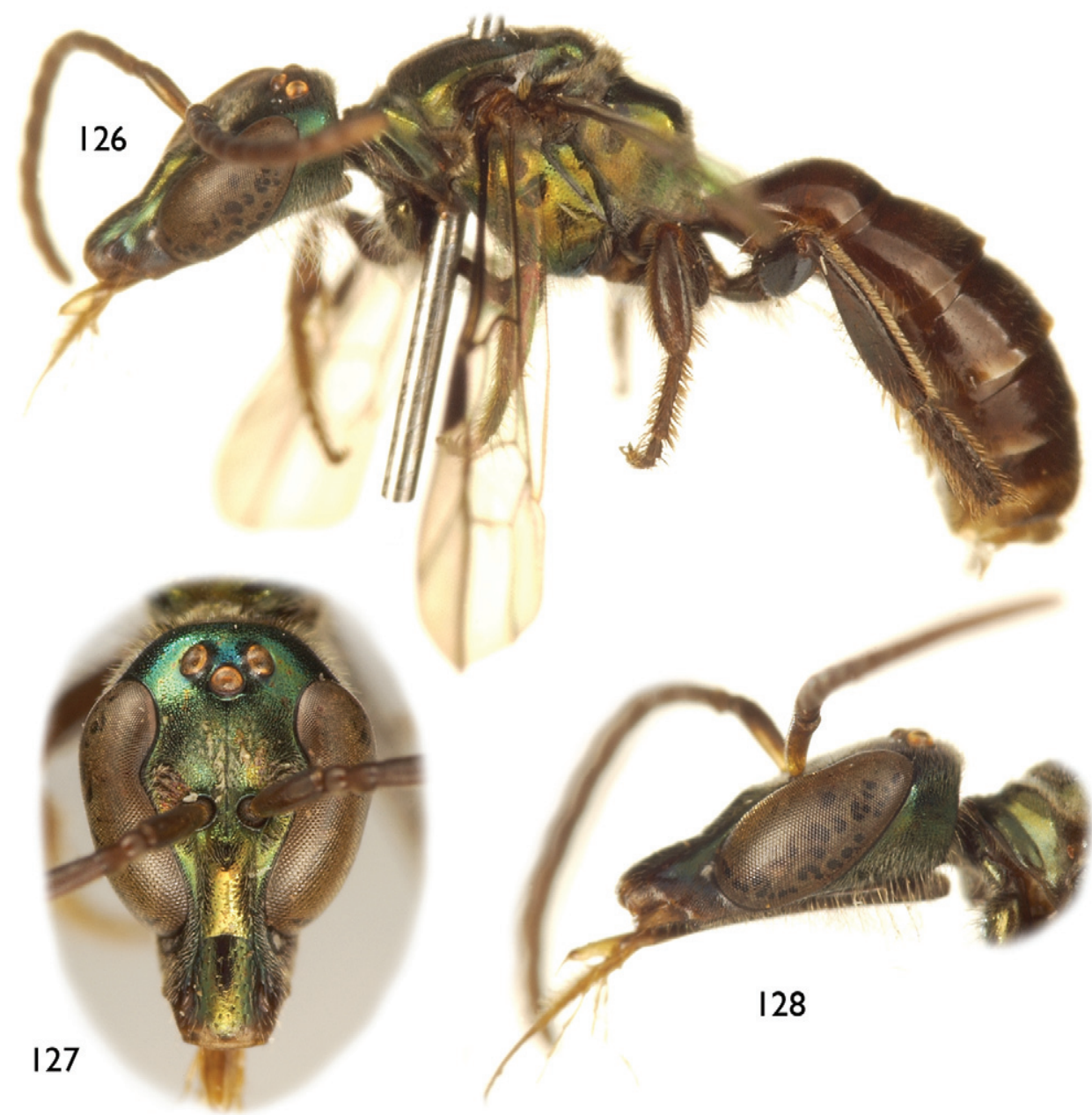

Figures I 26-I28. Holotype male of Chlerogella picketti sp. n. I 26 Lateral habitus I 27 Facial aspect 128 Lateral aspect of head.

apical margin of SV entire; apical margin of SVI emarginate; terminalia as depicted in figures 137 and 138.

Clypeus and supraclypeal area imbricate with weak punctures separated by 1-2 times a puncture width; face with small, punctures separated by a puncture width or less, integument between punctures smooth, more widely spaced in malar space; punctures of face blending to smooth integument in ocellocular area and vertex, with punctures separated by $1-1.5$ times a puncture width; gena smooth with small punctures separated by $1-2$ times a puncture width; postgena imbricate and impunctate. Pronotum finely imbricate with minute punctures separated by $1-3$ times a puncture width; mesoscutum smooth with small punctures separated by $0.5-1.5$ times a puncture width, anteromedially punctures becoming faint and integument somewhat imbricate; mes- 
oscutellum smooth with small punctures separated by a puncture width; metanotum finely imbricate with minute punctures separated by a puncture width. Preëpisternum smooth with punctures separated by a puncture width or less; mesepisternum smooth with small punctures separated by $0.5-2$ times a puncture width; metepisternum finely imbricate. Propodeum strongly imbricate. Metasoma finely imbricate.

Mandible pale yellow except reddish at apex; labrum pale yellow; clypeal apex with narrow longitudinal band of pale yellow, remainder of clypeus and head brilliant metallic green with copper or golden highlights, principally on clypeus and supraclypeal area. Antenna dark brown. Mesosoma brilliant metallic green with copper or golden highlights (Fig. 126); tegula dark brown. Wing membranes faintly infumate; veins dark brown. Legs dark brown. Metasoma dark brown.

Pubescence white to somewhat golden on legs and apically on metasoma. Typical gender pilosity except postgena with numerous elongate, sinuate setae, such setae with short apical branches; inner surfaces of trochanters (particularly dense on protrochanter), mesofemur, and metacoxa with elongate, apically-plumose setae, similar setae on inner surfaces of metatrochanter, base of metafemur, and metatibia except largely simple and somewhat sinuate. Apical margin of SIII with diffuse fringe of moderate-length white setae; SIV with small medioapical pads of short golden to fuscous setae bordering medial emargination; SV laterally with diffuse areas of long, inwardly-curved setae.

Female: Unknown.

Etymology. The specific epithet is a patronym honoring dear friend and colleague, Dr. Kurt M. Pickett of the University of Vermont, a leading authority on the systematics of Vespidae.

\section{Chlerogella cyranoi Engel, sp. n.}

urn:lsid:zoobank.org:act:AD85F7E7-5339-4752-8326-48E1E264BD70

Figs 129-131, 139-140, Map 4

Holotype. $\widehat{\jmath}$, Colombia: Porce, Ant. [Antioquia] Col, Tenche B., 2-4 Jama, 14/06/1997 [14 June 1997], A. Smith P. (MEFLG).

Diagnosis. Chlerogella cyranoi resembles to some degree $C$. azurea and other small metallic blue Chlerogella with elongate heads. The new species can be distinguished from them by the simple SIV, the lack of white markings at the clypeal apex (Fig. 131), and the longer malar space (Figs 130-131).

Description. Male: Total body length $7.62 \mathrm{~mm}$; forewing length $5.20 \mathrm{~mm}$. Head length $2.42 \mathrm{~mm}$, width $1.48 \mathrm{~mm}$. Clypeus beginning below lower tangent of compound eyes. Malar space 50.7\% compound eye length (malar length 0.65 $\mathrm{mm}$; compound eye length $1.28 \mathrm{~mm}$ ) (Figs 130-131). Upper interorbital distance $0.73 \mathrm{~mm}$; lower interorbital distance $0.39 \mathrm{~mm}$. First flagellomere about as long as pedicel, about as long as wide; second flagellomere 2.2 times length of first flagellomere; ventral surfaces of second through eleventh flagellomeres densely covered in placoid sensilla, placoid fields not disrupted. Upper portion of pronotum medially 


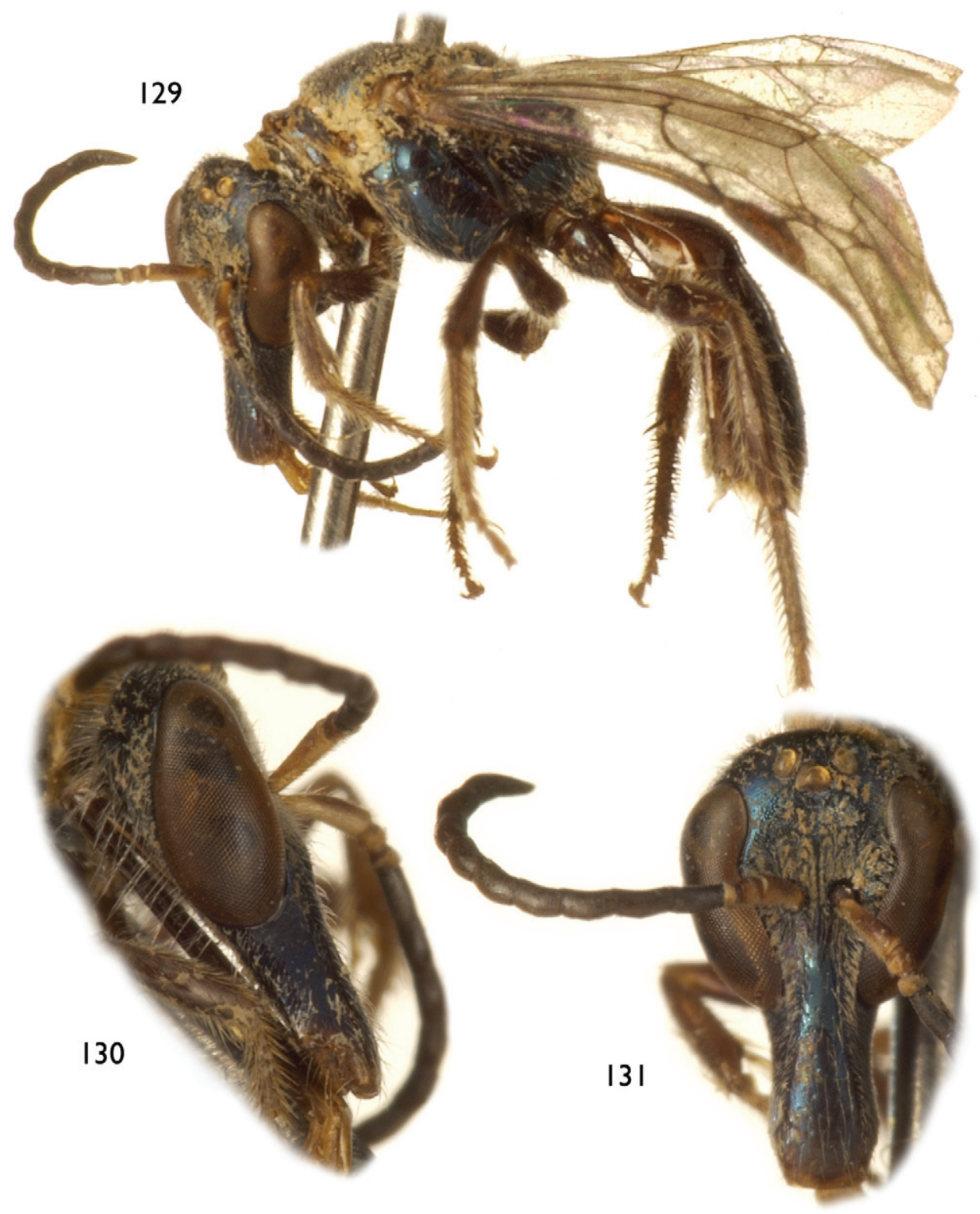

Figures I29-I3I. Holotype male of Chlerogella cyranoi sp. n. I29 Lateral habitus I30 Lateral aspect of head I 3 I Facial aspect.

depressed, not elongate, medially less than 0.25 times ocellar diameter in length; ventral portion of preëpisternal sulcus not broad, similar to scrobal sulcus and upper portion of preëpisternal sulcus; intertegular distance $0.98 \mathrm{~mm}$; mesoscutellum weakly convex, not bigibbous. Basal vein distad cu-a by two times vein width; $1 \mathrm{rs}-\mathrm{m}$ distad $1 \mathrm{~m}$-cu by vein width; 2 rs-m distad $2 \mathrm{~m}$-cu by five times vein width, 2 rs-m 
weakly arched; first submarginal cell longer than combined lengths of second and third submarginal cells; second submarginal cell slightly narrowed anteriorly, anterior border of second submarginal cell along Rs about one-half that of third submarginal cell; posterior border of third submarginal cell slightly less than twice length of anterior border. Distal hamuli arranged 2-1-2. Inner metatibial spur serrate. Apical margin of SIII entire; apical margin of SIV weakly indented medioapically, with small weak lobes lateral to weak medial concavity, without furrow in apical half of disc; apical margin of SV entire; apical margin of SVI emarginate; terminalia as depicted in figures 139 and 140 .

Clypeus and supraclypeal area finely imbricate with weak punctures separated by 0.5-2 times a puncture width; face with small, contiguous punctures, more widely spaced in malar space; punctures of face blending to smooth integument in ocellocular area and vertex, with punctures separated by $1-1.5$ times a puncture width; gena smooth with small punctures separated by 1-2 times a puncture width; postgena imbricate and impunctate. Pronotum smooth with scattered minute punctures; mesoscutum smooth with small punctures separated by 1-2 times a puncture width; mesoscutellum and metanotum as on mesoscutum. Preëpisternum smooth with small punctures separated by $2-3$ times a puncture width; mesepisternum smooth with small punctures separated by 2-6 times a puncture width, punctures weak; metepisternum faintly imbricate. Propodeum strongly imbricate. Metasoma finely imbricate.

Mandible yellow except reddish at apex; labrum yellow; clypeal apex narrowly yellow, remainder of clypeus and head brilliant metallic azurite blue. Antenna dark brown except ventral surface of scape yellow, pedicel and dorsal surface of scape brown. Mesosoma brilliant metallic azurite blue (Fig. 129); tegula dark brown. Wing membranes hyaline; veins dark brown. Legs dark brown. Metasoma dark brown.

Pubescence white. Typical gender pilosity except postgena with numerous elongate, sinuate setae, such setae with short apical branches. Apical margin of SIII without fringe, with diffusely scattered moderate-length white setae; SIV with small pads of short white to golden setae on small lobes bordering weak medial concavity; SV laterally with diffuse areas of long, inwardly-curved setae.

Female: Unknown.

Etymology. The specific epithet is a patronym honoring Hector Savinien de Cyrano de Bergerac (1619-1655), French dramatist who was famously known for his overly large nose.

\section{Chlerogella tychoi Engel, sp. n.}

urn:lsid:zoobank.org:act:68EB9F61-66A9-48C9-A75E-A74F0C6F2BFD

Figs 132-134, Map 4

Holotype. + , Colombia: Dept. Valle, Central de Anchicaya, $30 \mathrm{~km}$ E. Buenaventura, tropical, very wet forest, 560 m, 10.vi.1975 [10 June 1975], malaise trap, R.C. Wilkerson (SEMC). 


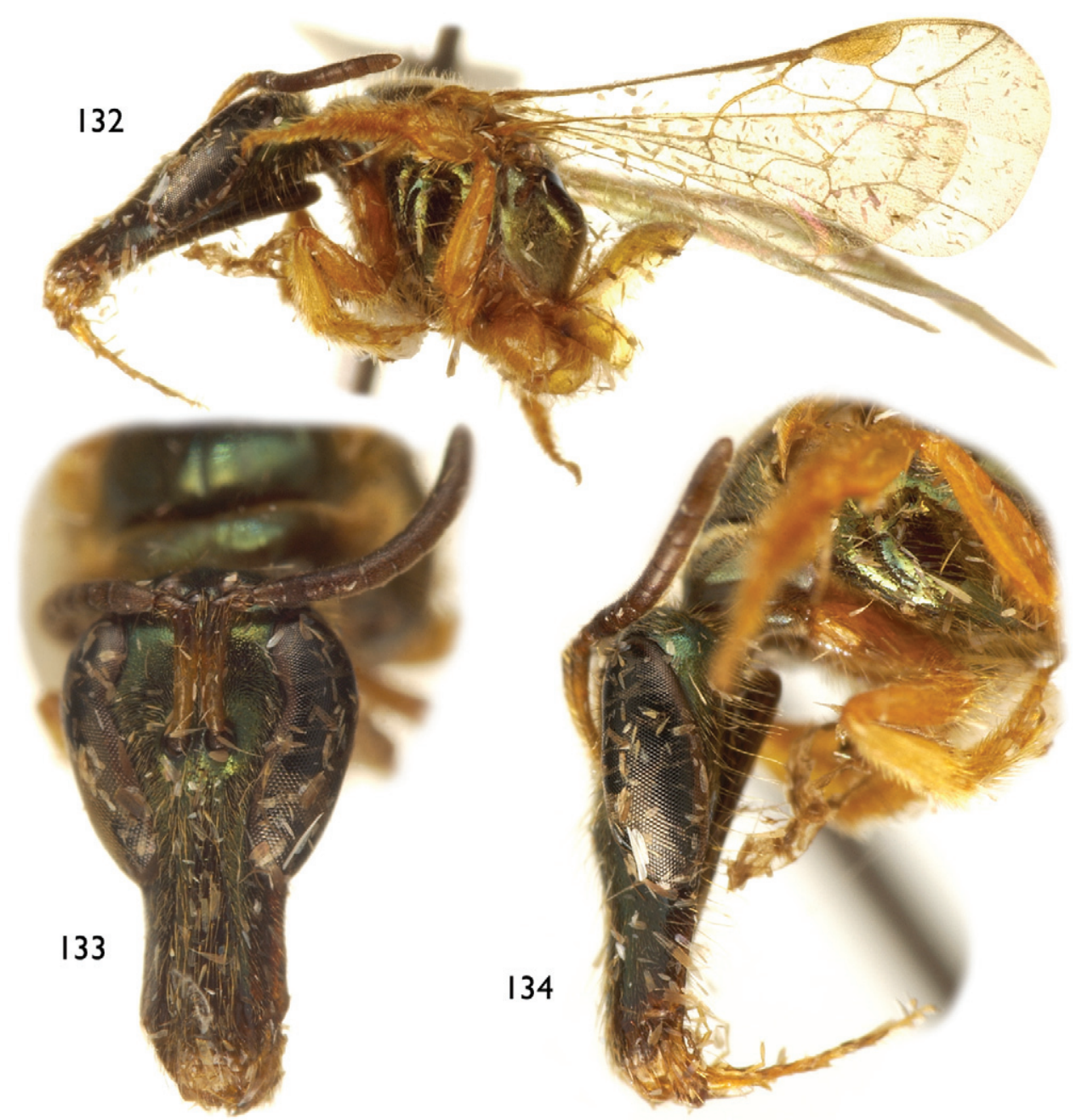

Figures 132-134. Holotype female of Chlerogella tychoi sp. n. 132 Lateral habitus 133 Facial aspect 134 Lateral aspect of head.

Diagnosis. Chlerogella tychoi superficially resembles C. terpsichore, also from southwestern Colombia, but differs notably in the much longer malar space (Fig. 133), structure of the inner metatibial spur, and coloration of the procoxae.

Description. Female: Total body length $7.7 \mathrm{~mm}$; forewing length $5.0 \mathrm{~mm}$. Head length $2.45 \mathrm{~mm}$, width $1.56 \mathrm{~mm}$. Clypeus beginning below lower tangent of compound eyes. Malar space $47.6 \%$ compound eye length (malar length $0.68 \mathrm{~mm}$; compound eye length $1.43 \mathrm{~mm}$ ) (Figs 133-134). Upper interorbital distance $0.73 \mathrm{~mm}$; lower interorbital distance $0.47 \mathrm{~mm}$. Upper portion of pronotum slightly swollen, medially about 1.5 times ocellar diameter in length; ventral portion of preëpisternal sulcus not broad, similar to scrobal sulcus and upper portion of preëpisternal sulcus; 

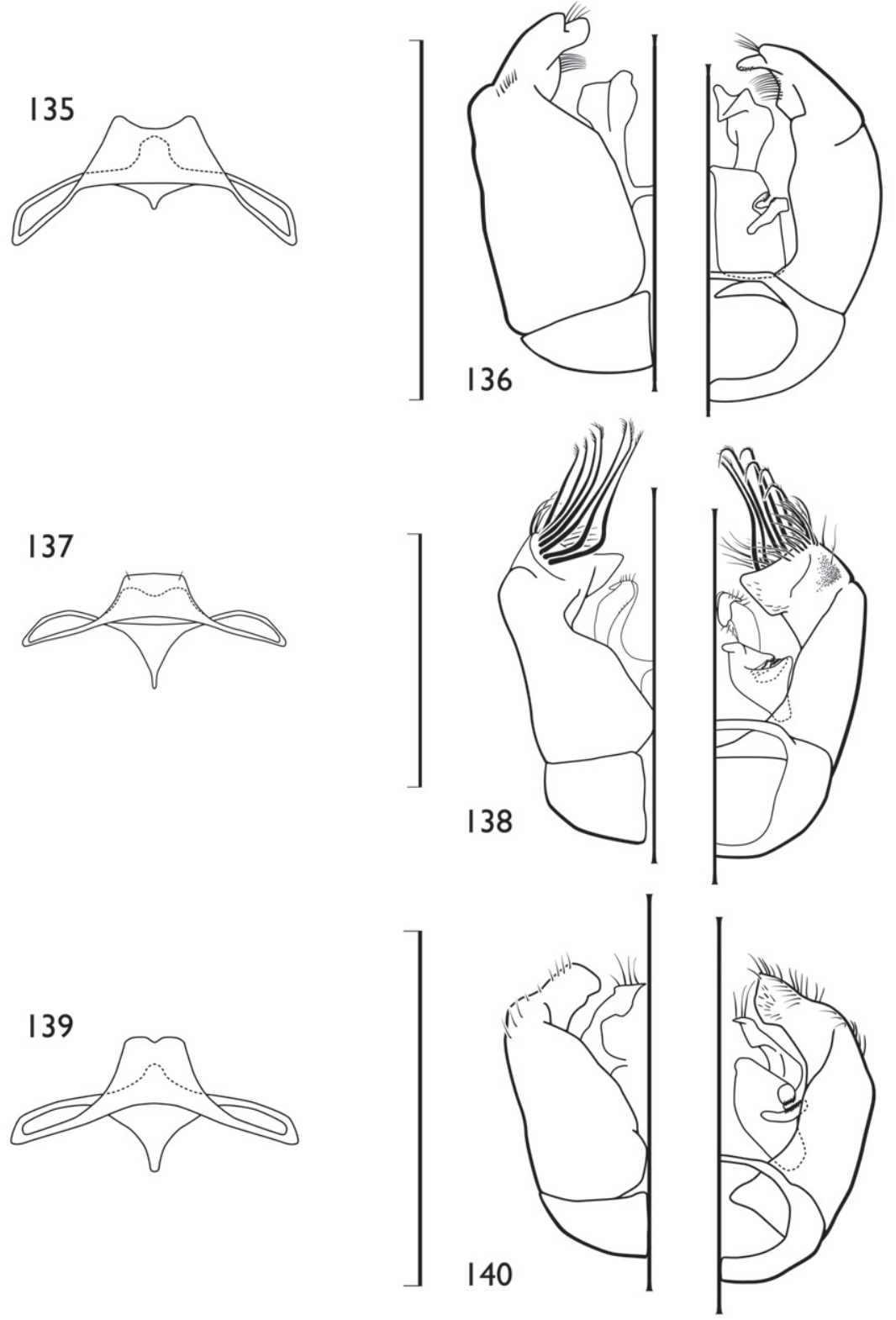

Figures 135-I 40. Male terminalia for Colombian Chlerogella species. 135 Chlerogella terpsichore sp. n., hidden and fused sterna VII and VIII 136 C. terpsichore sp. n., genital capsule (left is dorsal aspect, right is ventral aspect) 137 C. picketti sp. n., hidden and fused sterna VII and VIII 138 C. picketti sp. n., genital capsule (left is dorsal aspect, right is ventral aspect) I39 C. cyranoi sp. n., hidden and fused sterna VII and VIII I $\mathbf{4 0}$ C. cyranoi sp. n., genital capsule (left is dorsal aspect, right is ventral aspect). All scale bars $=1 \mathrm{~mm}$. 
intertegular distance $1.20 \mathrm{~mm}$; mesoscutellum weakly convex, not bigibbous. Basal vein distad cu-a by two times vein width; $1 \mathrm{rs}-\mathrm{m}$ distad $1 \mathrm{~m}-\mathrm{cu}$ by two times vein width; 2rs-m distad $2 \mathrm{~m}$-cu by six times vein width, 2rs-m weakly arched; first submarginal cell longer than combined lengths of second and third submarginal cells; second submarginal cell slightly narrowed anteriorly, anterior border of second submarginal cell along Rs about as along as that of third submarginal cell; posterior border of third submarginal cell about two times longer than anterior border. Distal hamuli arranged 2-1-2. Inner metatibial spur with eight branches (not including apical portion of rachis).

Clypeus and supraclypeal area smooth with weak punctures separated by 1-2 times a puncture width; face with small punctures separated by a puncture width or less; similar punctures and integument in ocellocular area and vertex; gena smooth with minute punctures separated by 1-4 times a puncture width; postgena imbricate and impunctate. Pronotum faintly imbricate with minute, scattered punctures; mesoscutum smooth with small punctures separated by a puncture width or less except outside of parapsidal lines separated by 0.5-2 times a puncture width; mesoscutellum smooth with minute punctures separated by a puncture width or less; metanotum faintly imbricate with minute punctures separated by 1-2 times a puncture width. Preëpisternum faintly imbricate with shallow punctures separated by $0.5-2$ times a puncture width; mesepisternum smooth blending to faintly imbricate ventrally, with minute and shallow punctures separated by 3-6 times a puncture width, punctures weak; metepisternum faintly imbricate. Propodeum strongly imbricate. Metasoma finely imbricate.

Mandible amber except reddish brown at apex; labrum amber; clypeal apex dark brown, remainder of clypeus and head brilliant metallic green. Antenna dark brown except basal two-thirds of scape amber. Mesosoma brilliant metallic green except pronotal lobe amber brown (Fig. 132); tegula translucent amber. Wing membranes largely hyaline, faintly tinged with yellow; veins brown except $\mathrm{C}$ and $\mathrm{Sc}+\mathrm{R}$ dark brown. Legs amber except procoxa brilliant metallic green. Metasomal TI, TII, SI, and SII amber, remainder of terga and sterna dark brown.

Pubescence golden.

Male: Unknown.

Etymology. The specific epithet is a patronym honoring Danish nobleman and astronomer Tycho Brahe, the Latinized name adopted by Tyge Ottesen Brahe de Knudstrup (1546-1601). During his life Tycho painstakingly catalogued celestial movements, data later used by individuals such as his assistant Johannes Kepler. As a student Tycho lost part of his nose in a duel and he apparently wore a prosthetic nose made of silver and gold, although speculation and evidence exists to suggest it was perhaps made of copper.

Comments. The holotype is in somewhat poor condition and was captured in a malaise trap with Lepidoptera. The metasoma and portions of the legs had become detached and were, at some point in the past, glued to edges of the locality label. An attempt was made to remove some of the numerous lepidopteran scales covering the 
individual but despite considerable cleaning there remains a preponderance of scales, however, they no longer obscure any surfaces or structures.

\section{Chlerogella oresbios Engel, sp. $\mathbf{n}$.}

urn:Isid:zoobank.org:act:EE411EA0-2FF0-4EA8-9F49-5FC333898A46

Figs 141-149, 154-155, Map 5

Holotype. + , Venezuela: Aragua, Rancho Grande Biol. Stn., 10²1'N, 67²41'W, 1370 m, 1-8 March 1995, R.W. Brooks, ex: flight intercept trap (SEMC).

Paratypes. Venezuela: 1으, Aragua, Parque Nac. H. Pittier, Rancho Grande, La Toma, 9.x.1992 [9 October 1992], 1100 m, sweep [net], J.L. Garcia, L. Chacón (CNC); $2 \widehat{\jmath}$, Aragua, Parque Nac. H. Pittier, Portachuello Pass, 13.iv.1994, 1000

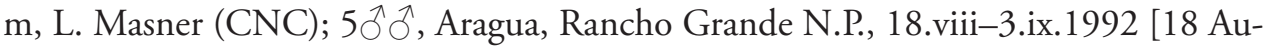
gust-3 September 1992], L. Masner, maxinet, cloud forest, $1000 \mathrm{~m}$ (CNC); 1ठ, Aragua, Rancho Grande N.P., 18.viii-3.ix.1992 [18 August-3 September 1992], L. Masner, maxinet, cloud forest, 1000 m (SEMC); 1 , Aragua, Rancho Grande Bio. Sta., H. Pittier N.P., 30 November 1982, N. Ramirez, \#AS-42, ex flowers "Corupelis" (CUIC);

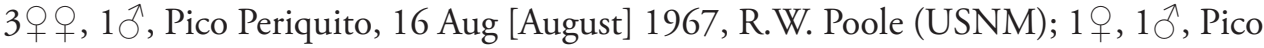
Periquito, 16 Aug [August] 1967, R.W. Poole (SEMC); 1 9 , Aragua, Rancho Grande Biol. Stn., Portachuelo Pass, 10²1'0"N, 67²41'0"W, 1100 m, 4 June 1998, J. Ashe, R. Brooks, R. Hanley, ex: insects moving through pass against wind migration (SEMC); 10̂, Aragua, Rancho Grande, 4.vii.1988 [4 July 1988], L. Stange, C. Porter (SEMC); 10, Aragua, Rancho Grande, 25 March-22 April 1960, F.H. Test (UMMZ); 1 , Aragua, P.N.H. Pittier, Rancho Grande, 1100 m, 17.ix.1993 [17 September 1993], F. Vasquez (MIZA); 10 , Aragua, P.N.H. Pittier, Cymino, La Cumbre, 1100-1500 m, 3.ix.1992 [3 September 1992], Barrido, J.L. Garcia (MIZA); 10 , Aragua, P.N.H. Pittier, La Toma, 1100 m, 2.ix.1992 [2 September 1992], J.L. Garcia (Barrido) (MIZA); 10̄, Aragua, P.N.H. Pittier, Rancho Grande, La Toma, 1100 m, 21.viii.1994 [21 August 1994], J.L. Garcia (Barrido) (MIZA).

Diagnosis. Chlerogella oresbios is most similar to C. cochabambensis from Bolivia (vide supra). The former can be distinguished by the more distinctive caerulean blue coloration, the more sparsely punctured mesoscutum, the relatively straight $2 \mathrm{rs}-\mathrm{m}$ in the forewing, the structure of the SIV and terminalia in males (Figs 149, 154-155), and the slightly smaller body size.

Description. Female: Total body length $8.17-8.76 \mathrm{~mm}$; forewing length $6.07-$ $6.13 \mathrm{~mm}$. Head length $2.35-2.37 \mathrm{~mm}$, width $1.56-1.64 \mathrm{~mm}$. Clypeus beginning at or minutely above lower tangent of compound eyes. Malar space $26.3-28.4 \%$ compound eye length (malar length $0.39-0.42 \mathrm{~mm}$; compound eye length $1.48 \mathrm{~mm}$ ) (Figs 142-143). Upper interorbital distance $0.82-0.84 \mathrm{~mm}$; lower interorbital distance $0.56-0.60 \mathrm{~mm}$. Upper portion of pronotum medially depressed, not elongate, medially less than 0.25 times ocellar diameter in length; ventral portion of preëpisternal sulcus distinctly broad dorsally at junction of scrobal sulcus and upper portion 


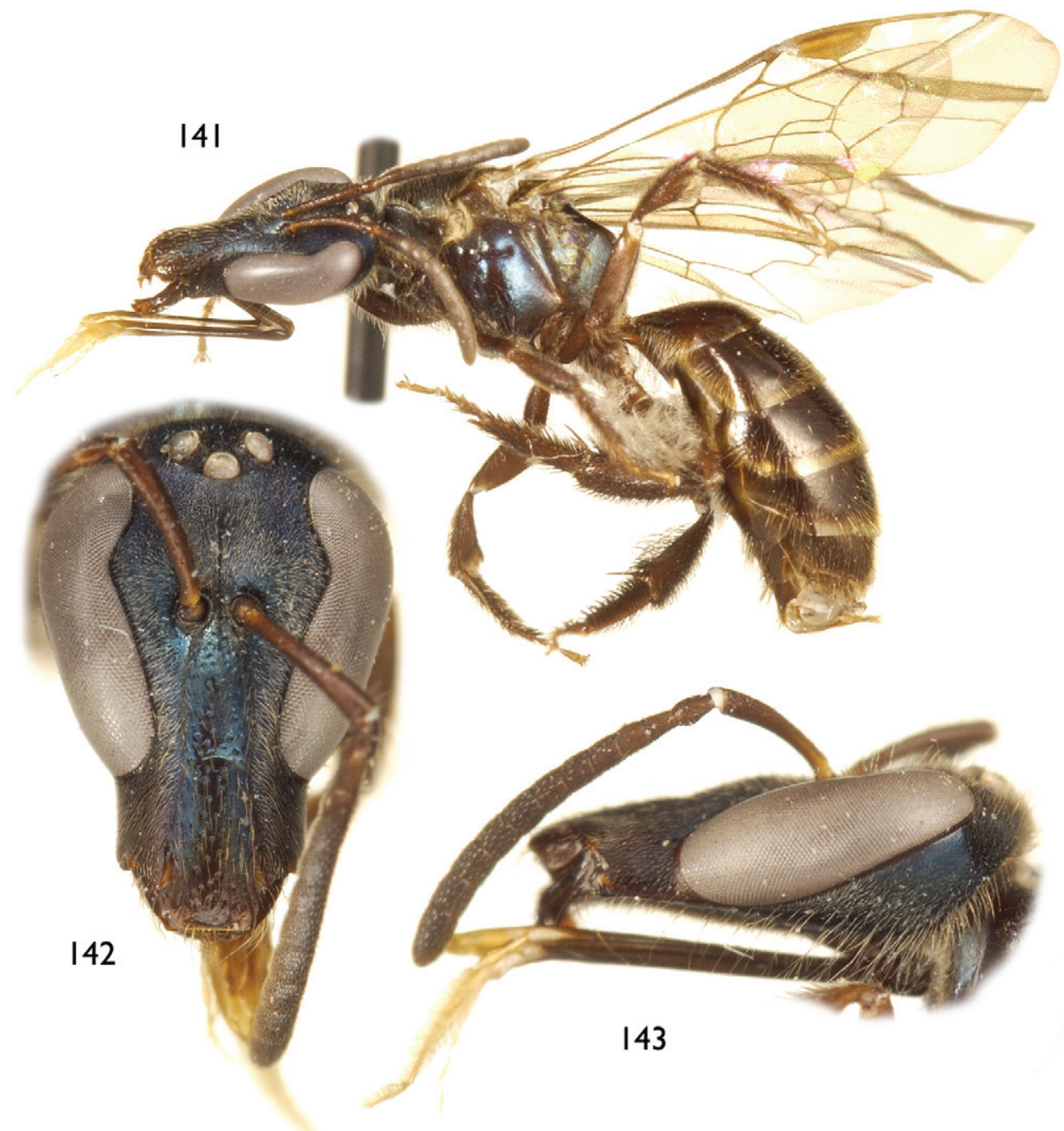

Figures |4|-|43. Female of Chlerogella oresbios sp. n. I4I Lateral habitus I42 Facial aspect I43 Lateral aspect of head.

of preëpisternal sulcus; intertegular distance $1.30-1.31 \mathrm{~mm}$; mesoscutellum weakly convex, not bigibbous. Basal vein distad cu-a by three times vein width; $1 \mathrm{rs}-\mathrm{m}$ distad $1 \mathrm{~m}$-cu by twice vein width; $2 \mathrm{rs}-\mathrm{m}$ distad $2 \mathrm{~m}$-cu by six times vein width, $2 \mathrm{rs}-\mathrm{m}$ straight; first submarginal cell longer than combined lengths of second and third submarginal cells; second submarginal cell not narrowed anteriorly, anterior border of second submarginal cell along Rs slightly longer than that of third submarginal cell; posterior border of third submarginal cell nearly two times longer than anterior border. Distal hamuli arranged 2-1-2. Inner metatibial spur with 6-7 branches (not including apical portion of rachis). 
Michael S. Engel/ ZooKeys 47: 1-100 (2010)

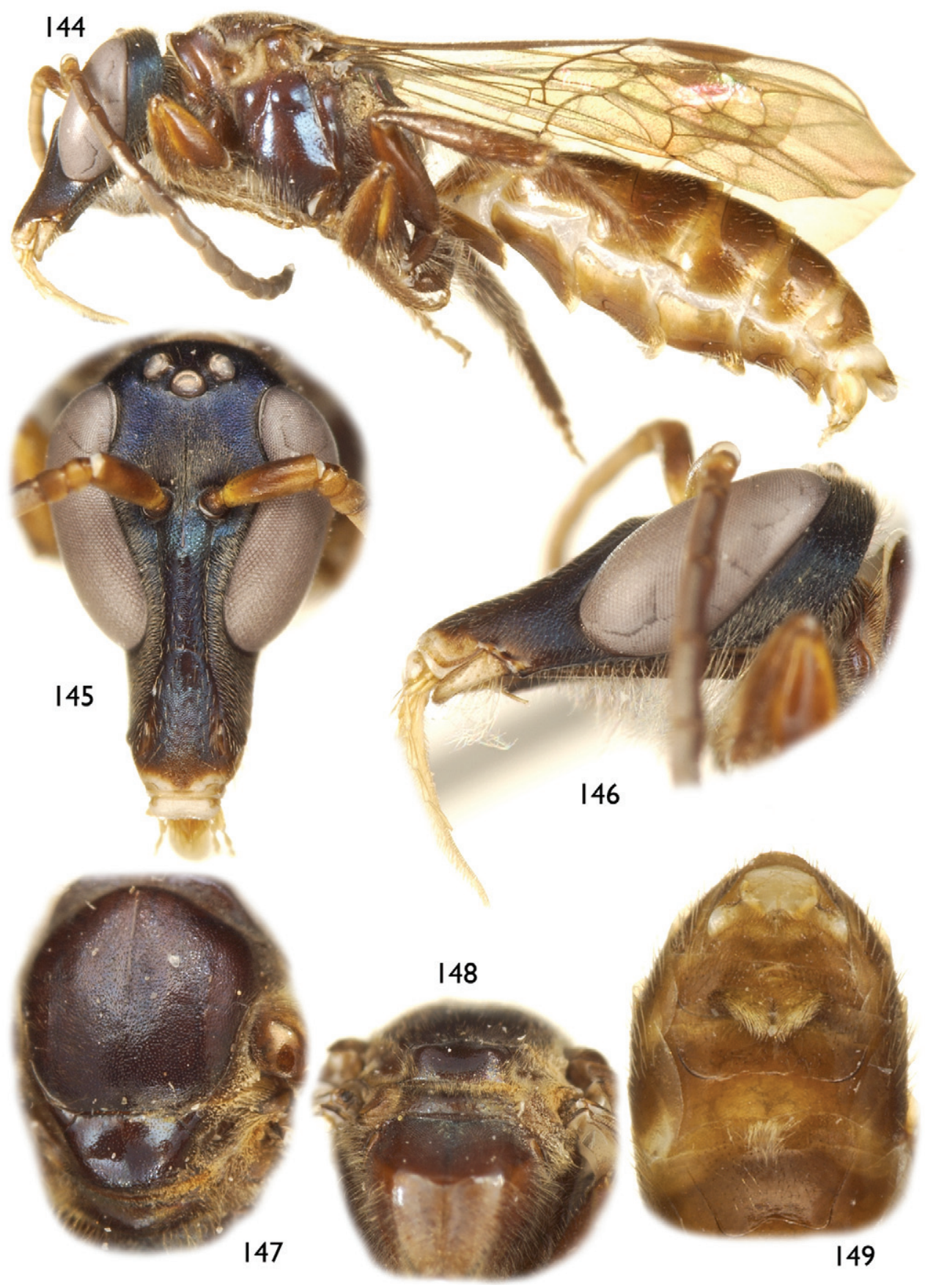

Figures I44-I49. Male of Chlerogella oresbios sp. n. I 44 Lateral habitus I 45 Facial aspect I 46 Lateral aspect of head 147 Mesoscutum and mesoscutellum, dorsal aspect 148 Posterior view of mesosoma 149 Apical metasomal sterna. 


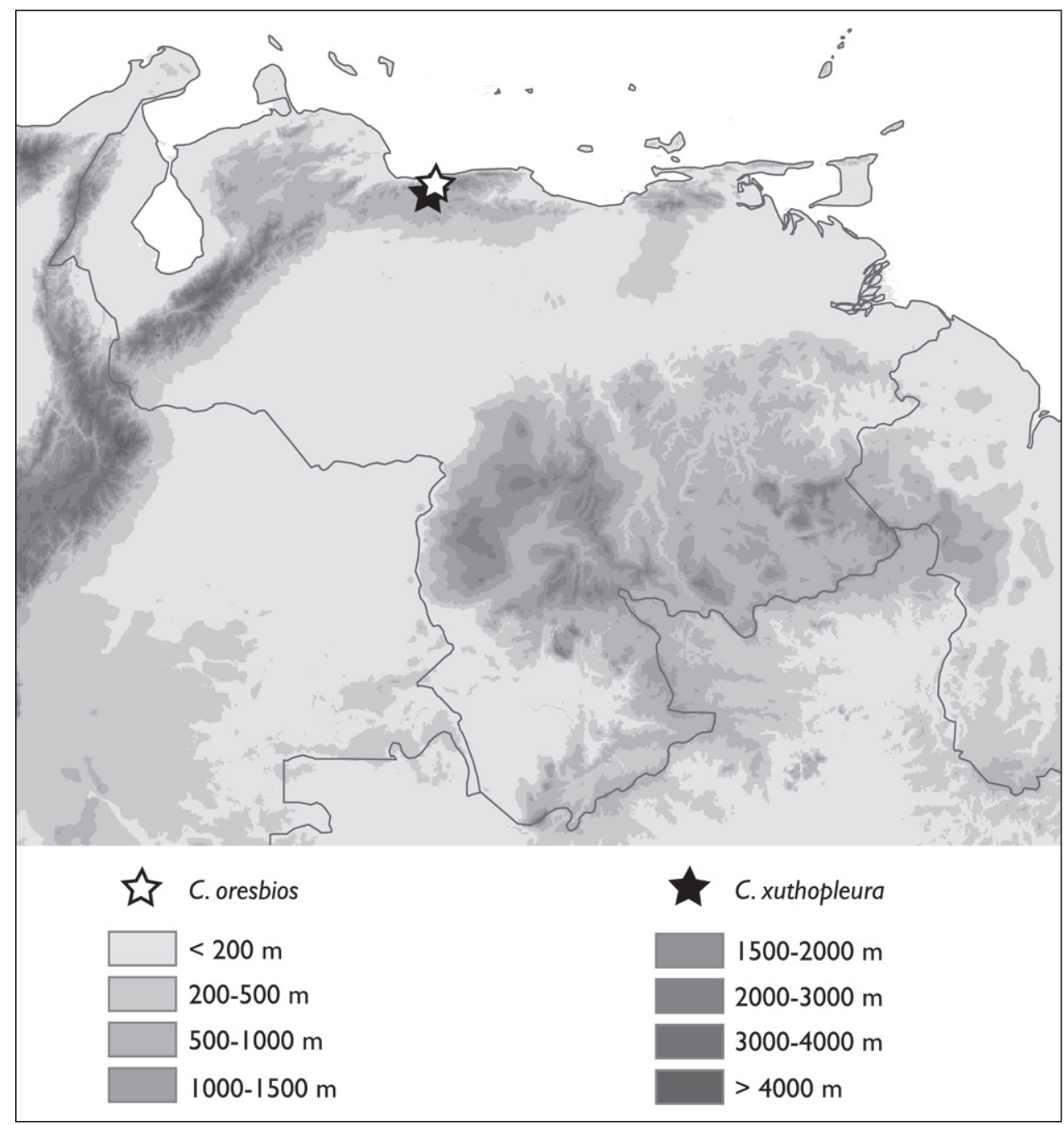

Map 5. Collection localities for Venezuelan Chlerogella.

Clypeus and supraclypeal area imbricate with weak punctures separated by $1-3$ times a puncture width; face with small, contiguous punctures, more widely spaced in malar space; punctures of face blending to colliculate or coarsely imbricate integument in ocellocular area and vertex, with minute punctures separated by $2-5$ times a puncture width; gena smooth with small punctures separated by 1-3 times a puncture width; postgena imbricate and impunctate. Pronotum imbricate with minute punctures separated by $1-3$ times a puncture width; mesoscutum coarsely imbricate with small punctures separated by $1-2$ times a puncture width on lateral thirds and along posterior border, medially punctures separated by 1-3.5 times a puncture width, medioanteriorly punctures becoming exceedingly faint to absent; mesoscutellum imbricate with small punctures separated by $0.5-1.5$ times a puncture width; metanotum imbricate with small punctures separated 
by $1-2$ times a puncture width. Preëpisternum smooth to faintly imbricate with small punctures separated by 1.5-4 times a puncture width; mesepisternum imbricate with small punctures separated by $2-5$ times a puncture width, punctures weak; metepisternum faintly imbricate. Propodeum strongly imbricate. Metasoma weakly imbricate.

Mandible dark brown except reddish at apex; labrum dark brown; clypeal apex dark brown, remainder of clypeus and head dark metallic blue. Antenna dark brown except ventral surfaces of flagellum slightly lighter. Mesosoma dark metallic blue (Fig. 141); tegula brown to dark brown. Wing membranes faintly yellowed or infumate; veins dark brown except pterostigma slightly lighter. Legs dark brown except apical tarsomeres slightly lighter. Metasoma dark brown, with apical margins of terga translucent light brown to brown.

Pubescence white to slightly golden except intermingled with fuscous setae on mesoscutum, mesoscutellum, metanotum, outer surfaces of protibia and protarsus, outer surfaces of mesotibia and mesotarsus, inner surface of metatibia, TIII-VI, and SIV-VI; black on inner surfaces of tarsi and tibiae.

Male: As described for the female except as follows: Total body length 8.96-9.79 $\mathrm{mm}$; forewing length $6.17-6.20 \mathrm{~mm}$. Head length $2.50-2.53 \mathrm{~mm}$, width $1.64-1.66$ $\mathrm{mm}$. Clypeus beginning below lower tangent of compound eyes. Malar space 28.6$29.1 \%$ compound eye length (malar length $0.44 \mathrm{~mm}$; compound eye length 1.51-1.54 $\mathrm{mm}$ ) (Figs 145-146). Upper interorbital distance 0.76-0.78 mm; lower interorbital distance $0.42-0.44 \mathrm{~mm}$. First flagellomere about as long as pedicel, about as long as wide; second flagellomere three times length of first flagellomere; ventral surfaces of second through eleventh flagellomeres densely covered in placoid sensilla, placoid fields not disrupted. Intertegular distance $1.25-1.33 \mathrm{~mm}$; mesoscutellum bigibbous (Figs 147-148). Inner metatibial spur serrate. Apical margin of SIII entire; apical margin of SIV medioapically produced, with narrow concave emargination between setose lobes, with narrow shallow medio-longitudinal furrow in apical half of disc, not bordered by carinae (Fig. 149); apical margin of SV weakly concave; apical margin of SVI emarginate; terminalia as depicted in figures 154 and 155.

Mandible, labrum, and clypeal apex white to off-white. Ventral surface and base of scape pale yellow to light brown. Inner surface of protibia, profemur, and inner apex of mesofemur yellow-brown to brown.

Typical gender pilosity except postgena with numerous elongate, sinuate setae, such setae with short apical branches; inner surfaces of trochanters, mesofemur, and metacoxa with elongate, apically-plumose setae, similar setae on inner surfaces of metatrochanter, metafemur, and metatibia except largely simple and somewhat sinuate, those of metatibia particularly elongate and sinuous at apices. Apical margin of SIII with fringe of moderate-length off-white to golden setae, such setae more dense medially to form small, narrow patch; SIV with medioapical pads of short golden to offwhite setae bordering medial emargination; SV laterally with diffuse areas of elongate, inwardly-curved setae.

Etymology. The specific epithet is a combination of the Greek terms oreos, meaning "mountain", and bios, meaning "life". 
Comments. A single female was labeled as being collected at flowers of "Corupelis". I have been unable to determine to what plant this name corresponds.

\section{Chlerogella xuthopleura Engel, sp. n.} urn:lsid:zoobank.org:act:B5A4CCA5-B856-437A-83A7-4660B2C70781 Figs 150-153, 156-157, Map 5

Holotype. ${ }^{\lambda}$, Venezuela: Aragua, Rancho Grande N.P., 18.viii-3.ix.1992 [18 August-3 September 1992], L. Masner, maxinet, cloud forest, $1000 \mathrm{~m}$ (CNC).

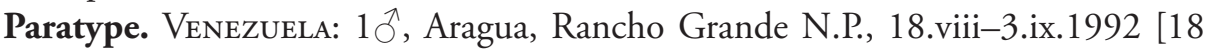
August-3 September 1992], L. Masner, maxinet, cloud forest, 1000 m (CNC).

Diagnosis. This species is similar to its compatriot $C$. oresbios but can be quickly recognized by the extensive yellow markings (Fig. 150, 153) and structure of the terminalia (Figs 156-157).

Description. Male: Total body length 7.92-8.42 mm; forewing length $5.80-6.13$ $\mathrm{mm}$. Head length $2.32-2.42 \mathrm{~mm}$, width $1.59-1.64 \mathrm{~mm}$. Clypeus beginning just below lower tangent of compound eyes. Malar space 31.2-32.2\% compound eye length (malar length 0.44-0.47 mm; compound eye length 1.41-1.46 mm) (Figs 151-152). Upper interorbital distance $0.70-0.73 \mathrm{~mm}$; lower interorbital distance $0.39-0.42 \mathrm{~mm}$. First flagellomere about as long as pedicel, about as long as wide; second flagellomere three times length of first flagellomere; ventral surfaces of second through eleventh flagellomeres densely covered in placoid sensilla, placoid fields not disrupted. Upper portion of pronotum medially depressed, not elongate, medially less than 0.25 times ocellar diameter in length; ventral portion of preëpisternal sulcus not broad, similar to scrobal sulcus and upper portion of preëpisternal sulcus; intertegular distance 1.15$1.22 \mathrm{~mm}$; mesoscutellum strongly bigibbous (Fig. 153). Basal vein distad cu-a by three times vein width; $1 \mathrm{rs}-\mathrm{m}$ distad $1 \mathrm{~m}$-cu by twice vein width; $2 \mathrm{rs}-\mathrm{m}$ distad $2 \mathrm{~m}$-cu by six times vein width, 2rs-m straight; first submarginal cell longer than combined lengths of second and third submarginal cells; second submarginal cell not narrowed anteriorly, anterior border of second submarginal cell along Rs about as long as that of third submarginal cell; posterior border of third submarginal cell nearly 1.75 times longer than anterior border. Distal hamuli arranged 2-1-2. Inner metatibial spur serrate. Apical margin of SIII entire; apical margin of SIV medioapically produced, with narrow concave emargination between setose lobes, with narrow shallow medio-longitudinal furrow in apical half of disc, not bordered by carinae; apical margin of SV weakly concave; apical margin of SVI emarginate; terminalia as depicted in figures 156 and 157.

Clypeus and supraclypeal area imbricate with weak punctures separated by 1-3 times a puncture width; face with small, contiguous punctures, more widely spaced in malar space; punctures of face blending to colliculate or coarsely imbricate integument in ocellocular area and vertex, with minute punctures separated by $2-5$ times a puncture width; gena smooth with small punctures separated by 1-3 times a puncture width; postgena imbricate and impunctate. Pronotum imbricate with minute punc- 


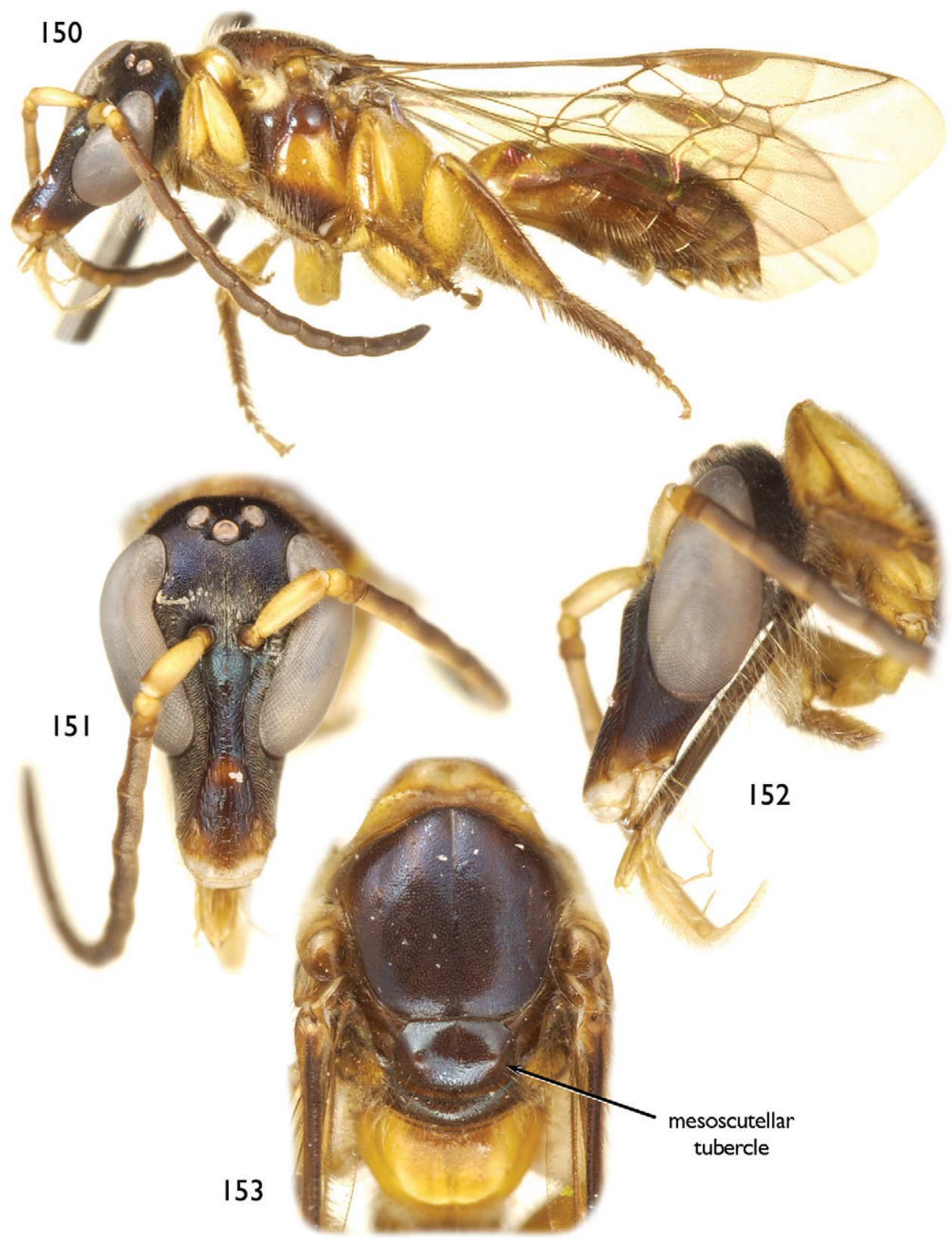

Figures I50-I53. Male of Chlerogella xuthopleura sp. n. I 50 Lateral habitus I5 I Facial aspect I52 Lateral aspect of head $\mathbf{I 5 3}$ Dorsum of mesosoma.

tures separated by $1-3$ times a puncture width; mesoscutum coarsely imbricate with small punctures separated by 1-2 times a puncture width on lateral thirds and along posterior border, medially punctures separated by $1-3.5$ times a puncture width, medi- 

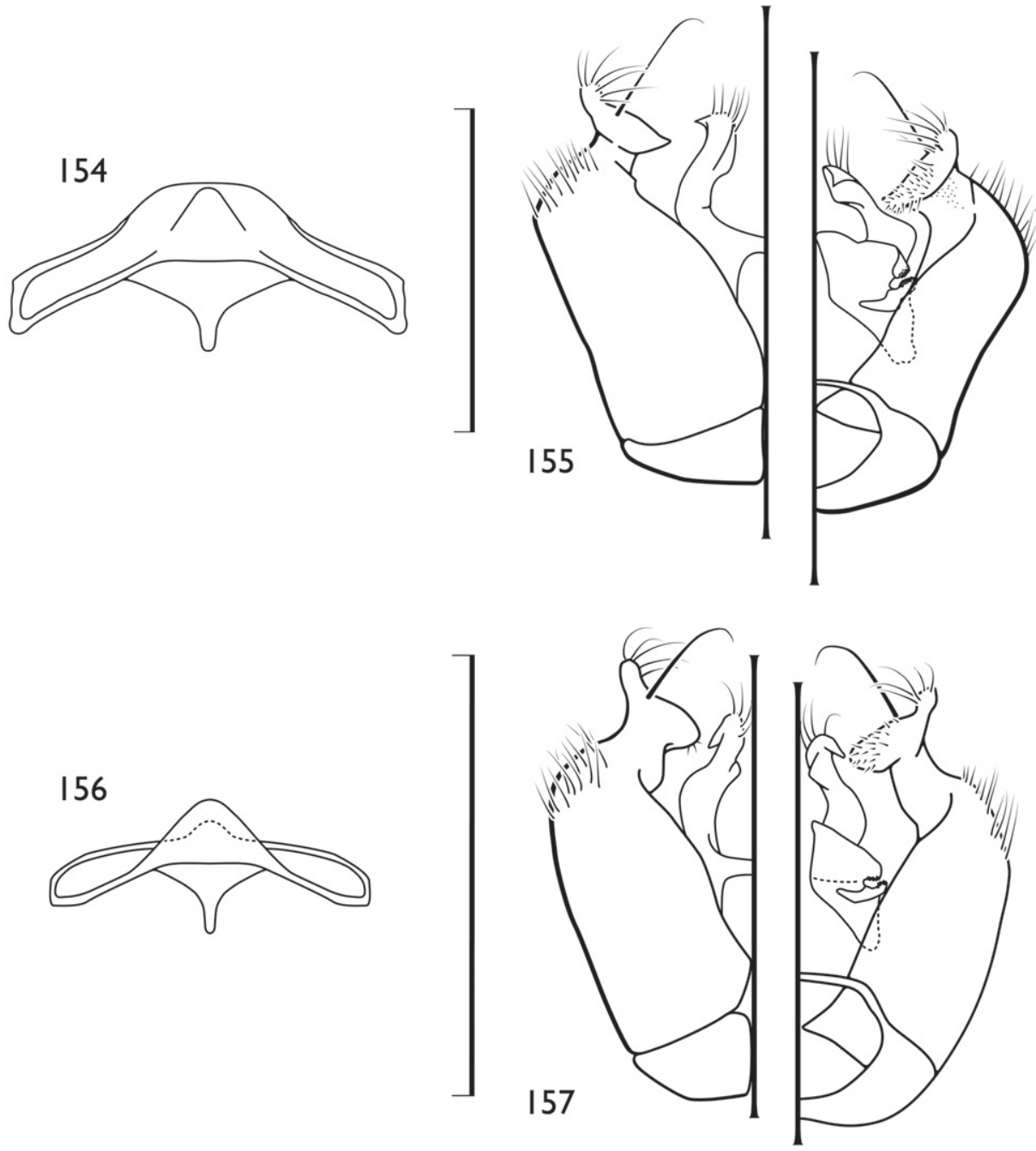

Figures 154-157. Male terminalia of Venezuelan Chlerogella species. 154 Chlerogella oresbios sp. n., hidden and fused sterna VII and VIII I55 C. oresbios sp. n., genital capsule (left is dorsal aspect, right is ventral aspect) 156 C. xuthopleura sp. n., hidden and fused sterna VII and VIII I57 C. xuthopleura sp. n., genital capsule (left is dorsal aspect, right is ventral aspect). All scale bars $=1.0 \mathrm{~mm}$.

oanteriorly punctures becoming exceedingly faint to absent; mesoscutellum imbricate with small punctures separated by $0.5-1.5$ times a puncture width; metanotum imbricate with small punctures separated by 1-2 times a puncture width. Preëpisternum smooth to faintly imbricate with small punctures separated by 1.5-4 times a puncture width; mesepisternum imbricate with small punctures separated by $2-5$ times a puncture width, punctures weak; metepisternum faintly imbricate. Propodeum strongly imbricate. Metasoma weakly imbricate. 
Mandible, labrum, and clypeal apex white, remainder of clypeus and head dark metallic blue (Figs 151-152), with yellowish brown patches at clypeal base and just apical of anterior tentorial pits in clypeus and malar space. Antenna brown except scape and pedicel yellow. Mesosoma dark metallic blue, with slight purplish tinge, except pronotum yellow but brown anteriorly, propodeum yellow (Fig. 150, 153), upper half mesepisternum yellow, and metepisternum yellow with brown area in upper half; tegula translucent yellowish brown, darker along posterior border. Wing membranes faintly yellowed or infumate; veins dark brown except pterostigma slightly lighter. Legs largely yellow, marked with brown on tibiae and tarsi brown to dark brown (Fig. 150). Metasoma brown except TI and TII yellow with apical margins brown and with apicomedial spot of brown connecting to brown marginal zone; sterna brown except SI and SII yellow with apical margins brown.

Typical gender pilosity except postgena with numerous elongate, sinuate setae, such setae with short apical branches; inner surfaces of trochanters, mesofemur, and metacoxa with elongate, apically-plumose setae, similar setae on inner surfaces of metatrochanter, metafemur, and metatibia except largely simple and somewhat sinuate, those of metatibia particularly elongate and sinuous at apices. Apical margin of SIII with moderately dense fringe of moderate-length off-white to golden setae; SIV with medioapical pads of short golden fuscous setae bordering medial emargination; SV laterally with diffuse areas of elongate, inwardly-curved setae.

Female: Unknown.

Etymology. The specific epithet is a combination of the Greek words xouthos, meaning "yellowish", and pleuron, meaning "side".

\section{Key to South American species of Chlerogella}

Females remain unknown for C. hauseri, C. nasus, C. xuthopleura, C. picketti, C. cooperella, C. octogesima, C. silvula, and C. cyranoi, and males for C. borysthenis, C. breviceps, C. dolichorhina, C. euprepia, C. rostrata, C. tychoi, C. vachali, and C. mourella. Chlerogella buyssoni from Perú is of uncertain status and requires either rediscovery of the holotype or new material. Currently understood countries of distribution are summarized in the couplets but are not meant as identifying "traits".

Naturally, some difficulties among the species remain and my temporary solution for the complex of metallic blue species in Perú and Ecuador is less than satisfactory. The challenges of small sample sizes from only a relatively few localities has rendered this a noticeable problem in the genus, and after considerable time it is apparent that sufficient material will not be forthcoming any time soon. While males from these areas can be readily distinguished on the basis of metasomal sterna and genitalia, the differences among females are much more subtle and I would have preferred to rely on more clearly diagnostic traits. Using the same standards and minor traits that appear to segregate the females of $C$. azurea, C. materdonnae, and C. agaylei across other females of this complex from the region necessitated the creation of two additional species, $C$. dolichorhina and 
C. rostrata. These all may be valid species and as more material amasses, particularly males, there eventually may be found features which more accurately diagnose those circumscribed herein. Alternatively, one or two may require synonymy. Thus, the current composition of species should be considered with caution and hopefully at some point in the future sufficiently large sample sizes of males and females from numerous localities across both countries will provide someone the opportunity to more carefully resolve the matter.

Females 2

- Males 19

2(1) Malar space about as long as or shorter than basal width of mandible (malar space less than 1.5 times basal mandibular width), rarely absent, with lower tangent of compound eye abutting base of mandible Malar space much longer (malar space at least 1.75 times longer than basal mandibular width, frequently much more) than basal mandibular width ... 9

3(2) Malar space present, with at least some noticeable portion of integument separating lower tangent of compound eye and mandibular base (malar space 0.4-1.5 times basal mandibular width)

- Malar space effectively absent, lower tangent of compound eye abutting mandibular base (malar space less than 0.25 times basal mandibular width) (Figs. 19-20) (Perú)

4(3) Malar space distinctly shorter than basal mandibular width (0.4-0.75 times basal mandibular width) (e.g., Figs 25-26, 75-76, 78-79)

- Malar space about as long as basal mandibular width (0.9-1.5 times basal mandibular width) (e.g., Figs 63-64, 93-94)

5(4) Head and mesoscutum shining, brilliant metallic blue (e.g., Figs 24-26, 7779); wings hyaline.

Head and mesoscutum dull, dark metallic greyish blue-green or greenish blue (Figs 74-76); wings infumate (Ecuador) C. borysthenis sp. $\mathrm{n}$.

6(5) Metasoma dark brown without amber or light brown markings; anterior margin of second submarginal cell as long as or slightly longer than anterior margin of third submarginal cell; malar space about three-quarters basal mandibular width (Figs 78-79); mesoscutum with punctures separated by a puncture width or less; larger species, total length about $7.2 \mathrm{~mm}$ (Ecuador).

C. breviceps sp. $\mathrm{n}$.

Metasoma dark brown with amber brown spot centrally on anterior-facing surface of first metasomal tergum and tergal margins translucent light brown (Fig. 24); anterior margin of second submarginal cell three-quarters length or less than anterior margin of third submarginal cell; malar space slightly less than one-half basal mandibular width (Figs 25-26); mesoscutum with punctures separated by one or more times a puncture width; smaller species, total length about $6.4 \mathrm{~mm}$ (Perú). C. vachali sp. $\mathrm{n}$. 
7(4) Head and mesosoma not black, brilliant metallic blue or green (e.g., Figs. 6264, 99-101).

- $\quad$ Head and mesosoma black, without metallic coloration (Figs 92-94) (Ecuador) .......................................................................... mourella Engel

8(7) Metasoma dark brown to black (Fig. 62); head and mesosoma bright metallic blue, with some faint purple highlights (Figs 62-64) (Ecuador)

C. eumorpha sp. n.

- $\quad$ Metasoma, at least T1-T3, amber (Fig. 99); head and mesosoma metallic green (Figs 99-101), with faint to strong opalescence on mesoscutum when viewed from some angles (Figs 102-103) (Ecuador)

C. elysia sp. n.

9(2) Metasoma with at least T1-T2 largely or entirely amber and other terga variable, but frequently with some brown coloration; scopal setae golden yellow; metatibia without fuscous setae; head and mesosoma frequently brilliant metallic green, copper-green, or copper-red, rarely dark brown with weak metallic copper green highlights 10

- $\quad$ Metasoma entirely dark brown to black; scopal setae largely white, becoming fuscous in some areas; metatibia with distinct coarse black setae at apex and frequently along length; head and mesosoma brilliant metallic blue or dark blue (sometimes with metallic purple highlights), or dark brown with strong metallic blue or blue-purple highlights 14

10(9) Hypostomal ridge carinate along entire length ........................................ 11

- $\quad$ Hypostomal ridge carinate posteriorly, becoming distinctly raised and lamellate anteriorly (Figs 109-110) (Ecuador, Colombia)...... C. hypermeces sp. n.

11(10) Mesoscutellum and metanotum concolorous with remainder of mesosoma ....12 Mesoscutellum and metanotum largely amber (Fig. 98), contrasting with metallic coloration of remainder of mesosoma (Ecuador).....

C. euprepia sp. $\mathrm{n}$.

12(11) Head and mesosoma brilliant metallic green; metasoma entirely amber ... 13 Head and mesosoma dark brown with weak metallic copper-green highlights (Figs 27-29); metasoma largely dark brown except amber brown on anterior segments

C. nasus (Enderlein)

13(12) Malar space about two times basal mandibular width (Figs 120-121); inner metatibial spur with five branches; procoxa amber (Colombia)....... C. terpsichore sp. $\mathbf{n}$.

- $\quad$ Malar space slightly more than four times basal mandibular width (Fig. 133); inner metatibial spur with eight branches; procoxa brilliant metallic green (Colombia) C. tychoi sp. n.

14(9) Malar space about 2-2.5 times basal mandibular width ........................... 15

- Malar space about 2.9-3.9 times basal mandibular width ......................... 16

15(14) Color more dull, muted caerulean blue over a dark brown integument (Figs. 2-4); mesoscutum with punctures separated by a puncture width or less laterally; 2rs-m gently arched; typically a slightly larger species, total length 8.9-9.5 mm (Bolivia)

C. cochabambensis sp. $\mathrm{n}$.

- $\quad$ Caerulean blue coloration generally more distinct (Figs 141-143); mesoscutum with punctures separated by $1-2$ times a puncture width laterally; $2 \mathrm{rs}-\mathrm{m}$ 
relatively straight; typically a slightly smaller species, total length $8.1-8.8 \mathrm{~mm}$ (Venezuela) C. oresbios sp. n.

16(14) Mesepisternum smooth to imbricate, frequently shiny, with minute weak punctures (largely at setal bases) of varying densities

- $\quad$ Mesepisternum strongly and coarsely imbricate, relatively dull, with coarse shallow punctures separated by $1.5-4$ times a puncture width (Ecuador) .....

C. dolichorbina sp. $\mathbf{n}$.

17(16) Mesepisternum smooth to imbricate, punctures of relatively equivalent density (sometimes slightly more close spaced ventrally but never as dramatically so as in alternate half of couplet) in both upper and lower portions of mesepisternum (Ecuador) 18

- $\quad$ Mesepisternum finely imbricate with punctures widely spaced in upper half, separated by $2-5$ times a puncture width, blending to noticeably more dense posteriorly and ventrally, separated by $0.5-2$ times a puncture width (Perú)...

C. rostrata sp. $\mathrm{n}$.

18(17) Head and mesosoma more bright azurite blue in color, frequently with strong metallic purple highlights (Figs 33-35, 48-50); mesepisternum smooth and shining to faintly imbricate (Perú, Ecuador) ......C. agaylei sp. n., C. azurea (Enderlein)

- $\quad$ Head and mesosoma, particularly pleura, more bright cerulean blue in color (Figs 55-57); mesepisternum imbricate with punctures separated by 2-4 times a puncture width (Ecuador).

C. materdonnae sp. $\mathrm{n}$.

19(1) Malar space less than 1.75 times basal mandibular width (frequently shorter) (e.g., Figs 22-23, 66-67, 81-82, 85-86, 105-106, 127-128) Malar space two or more times longer (frequently longer) than basal mandibular width (e.g., Figs 6-7, 10-11, 37-38, 52-53, 59-60, 112-113, $123-$ $124,130-131,145-146,151-152)$

20(19) Malar space 0.9-1.75 times basal mandibular width (e.g., Figs 66-67, 81$82,85-86,105-106,127-128)$

- Malar space linear, almost absent, much shorter than basal mandibular width, less than 0.25 times basal mandibular width (Figs 22-23) (Perú)

C. arhyncha sp. n.

21(20) Male metabasitarsus without elongate spine at inner base 22

- Male metabasitarsus with elongate spine at inner base and orthogonal to length of metabasitarsus (Fig. 83) (Ecuador) C. cooperella sp. n.

22(21) Metasoma dark brown, without large amber markings; legs dark brown ....23 Metasoma entirely amber or with extensive amber areas on basal terga; legs amber

23(22) Integument of head and mesosoma brilliant metallic blue (Figs 65-67); elongate setae ventrally along length of metafemur; pronotum somewhat swollen, dorsal expansion about one median ocellar diameters in length; genitalia as in figures $72-73$ (Ecuador) C. eumorpha sp. n.

- $\quad$ Integument of head and mesosoma brilliant metallic green (Figs 126-128); elongate setae ventrally confined to basal third of metafemur; pronotum 
weakly depressed medially, only weakly expanded; genitalia as in figures 137-138 (Colombia)

C. picketti sp. n.

24(22) Head and mesoscutum without opalescence; malar space less than 1.5 times basal mandibular width

- $\quad$ Head and mesoscutum with faint to strong opalescence; malar space slightly more than 1.5 times basal mandibular width (Ecuador)....

C. elysia sp. n.

25(24) Apical setae on SIII-IV diffuse, not developed into distinct fringes; diffuse apicolateral setae on SV distinctly and greatly elongate; ventral fringe of setae on ventral gonostylar process elongate, not thickened (Fig. 91); penis valves dorsoapically with distinctly elongate setae (Ecuador)

C. silvula sp. $\mathbf{n}$.

- $\quad$ Apical setae on SIII-IV forming dense fringes; diffuse, elongate apicolateral setae on SV absent; ventral fringe of setae on ventral gonostylar process decreasing in length to very short apically, such setae distinctly thickened and hooked apically; penis valves without elongate setae dorsoapically (Ecuador)

C. octogesima (Brooks \& Engel)

26(19) Metasoma entirely amber or with extensive amber on at least basal metasomal

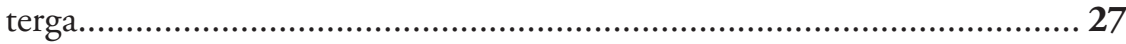

- Metasoma brown to dark brown, without extensive amber markings on first two metasomal terga .......................................................... 30

27(26) Mesoscutellum not bigibbous or only weakly so............................... 28

- $\quad$ Mesoscutellum distinctly bigibbous (Fig. 153) (Venezuela)

C. xuthopleura sp. n.

28(27) Malar space more than five times as long as basal mandibular width (Figs. 10 11, 112-113); first flagellomere about as long as pedicel; second flagellomere about two times longer than first flagellomere; SIV without elongate apicolateral projections; large species, total length 10.8-11.7 $\mathrm{mm}$.

- Malar space about two times as long as basal mandibular width (Figs 123124); first flagellomere longer than pedicel, nearly twice as long; second flagellomere three or more times longer than first flagellomere; SIV with elongate apicolateral projections (Fig. 125); medium-sized species, total length 8.5-8.7 mm (Colombia)

C. terpsichore sp. n.

29(28) Apical half of clypeus and apicalmost portion of malar space amber, remainder metallic copper to copper-green (Figs 112-113); pterostigma amber yellow in color; SIV as in figure 114; majority of head and mesosoma metallic copper green (Figs 111-113); malar space over six times basal mandibular width (Ecuador, Colombia)

C. hypermeces sp. $\mathrm{n}$.

- $\quad$ Entirety of clypeus and larger portion of malar space yellow (Figs 10-11); pterostigma brown in color; SIV as in figure 13; majority of head and mesosoma dark metallic green, with entirety of clypeus and majority of malar space yellow (Figs 9-11); malar space 5.6-5.7 times basal mandibular width (Bolivia)

C. hauseri sp. $\mathrm{n}$.

30(26) Head and mesosoma dark metallic blue or dark brown to black with metallic blue highlights (e.g., Figs 5-7, 144-146) 
- Head and mesosoma brilliant metallic blue frequently with strong purple highlights or appearing almost entirely purple (e.g., Figs 37-38, 52-53, 5960, 130-131).

31(30) Metasomal SIV as in figure 8; head more dark brown to black, with weaker blue highlights (Figs 5-7); malar space more than four times basal mandibular width (Bolivia) C. cochabambensis sp. $\mathbf{n}$.

- $\quad$ Metasomal SIV as in figure 149; head more noticeably blue (Figs 144-146); malar space slightly less than three times basal mandibular width (Venezuela). C. oresbios sp. $\mathbf{n}$.

32(30) Mesoscutellum not bigibbous, gently convex ...................................... 33 - $\quad$ Mesoscutellum bigibbous, with two low paramedial tubercles (Ecuador) .....

33(32) Metasomal SIV unmodified ........................................................... 34

- $\quad$ Metasomal SIV as in figure 54 (Ecuador)

C. agaylei sp. n.

34(33) Malar space more than 4.5 times basal mandibular width; clypeal apex dark brown (Fig. 131) (Colombia)

C. cyranoi sp. $\mathbf{n}$.

- Malar space slightly less than four times basal mandibular width; clypeal apex white (Fig. 37) (Perú, Ecuador).....

C. azurea (Enderlein)

\section{Acknowledgements}

This paper represents the final planned contribution to a series of taxonomic treatments of long-malared augochlorine genera. The author is grateful to the following curators for providing material under their stewardship and for their gracious patience during the long gestation of this study: J.G. Rozen, Jr. (AMNH), J.T. Huber, G.A.P. Gibson, A.M.R. Bennett (CNC), T.L. Griswold (BLCU), G. Lamas (MUSM), G. Onore (QCAZ), M. Cooper (COOP), J.K. Liebherr and E.R. Hoebeke (CUIC), M.A. Gaiani (MIZA), A.T. Finnamore, M. Buck (PMAE), R.J. McGinley, B. Harris (USNM), M.F. O’Brien (UMMZ), L. Packer (YORK), F. Koch (ZMHB), A.H. Smith-Pardo (MEFLG), and M. Hauser and S.D. Gaimari (CSCA). The author is further grateful to J. Casevitz-Weulersse (Museum National d'Histoire Naturelle) who hosted his 1996 visit to Paris during which he hunted for Vachal's "Chlerogella” holotype; to C.M. Taylor (Missouri Botanical Garden) for information on Psychotria pongoana; to A.E.Z. Short for couriering specimens back to Venezuela; and to J. Wiley (Florida State Collection of Arthropods) for generously donating to SEMC two important Chlerogella specimens for this study. Various colleagues provided interesting discussions, material, or assistance regarding Chlerogella over the years, most notably C.D. Michener, D. Brzoska, B.W.T. Coelho, J.G. Rozen, Jr., I.A. Hinojosa-Díaz, D.J. Bennett, J.C. Thomas, M. Buck, J.S. Ascher, R.W. Brooks, and A.H. Smith-Pardo. During the numerous years of this project, which was initiated in 1994, several institutions and agencies provided logistical and financial support, to each 
of whom considerable thanks is owed [project years: Cornell University (1994-1998), American Museum of Natural History (1998-2000), University of Kansas Natural History Museum (2000-2010)]. The final years of the project were partially funded by U.S. National Science Foundation grants DBI-0096905, EF-0341724, and DEB-0542909 (all to M.S.E.), while significant emotional support, patience, and understanding for the last push to complete the paper was provided by the author's wife, K.K.M. Engel, to whom he is deeply and forever indebted. Line drawings were prepared by S.L. Taliaferro, supported by the Engel Illustration Fund from the University of Kansas College of Liberal Arts \& Sciences. Locality data was in some cases retroactively georeferenced by I.A. Hinojosa-Díaz who, with assistance from M. Papeş, produced preliminary versions of the maps. Lastly, a tremendous debt is owed to L. Penev for graciously waiving fees so that this work could be published expeditiously; to I. Stoyanov for his excellent assistance in the review and production process; and to A. Pauly and an V.H. Gonzalez for their valuable insights and comments. This contribution is dedicated to Frederick Smith (1806-1879), Joseph Vachal (1838-1911), Heinrich Friese (1860-1948), Theodore D.A. Cockerell (1866-1948), and Padre Jesús S. Moure (1912- ), five major pioneers of augochlorine taxonomy (part I of this work was dedicated to the greatest pioneer of the Augochlorini, the late George C. Eickwort). This is a contribution of the Division of Entomology, University of Kansas Natural History Museum.

\section{References}

Brooks RW, Engel MS (1998) New bees of the genus Ischnomelissa Engel, with a key to the species (Hymenoptera, Halictidae, Augochlorini). Deutsche Entomologische Zeitschrift 45(2): 181-189.

Brooks RW, Engel MS (1999) A revision of the augochlorine bee genus Chlerogas Vachal (Hymenoptera: Halictidae). Zoological Journal of the Linnean Society 125(4): 463-486.

Dodson CH (1965) Agentes de Polinización y su Influencia sobre la Evolución en la Familia Orquidaceae. Universidad Nacional de la Amazonia Peruana, Iquitos, [iv]+vi+128 pp.

Eickwort GC (1969) A comparative morphological study and generic revision of the augochlorine bees (Hymenoptera: Halictidae). University of Kansas Science Bulletin 48(13): 325-524.

Enderlein G (1903) Drei neue Bienen mit rüsselartiger Verlängerung des Kopfes. Berliner Entomologische Zeitschrift 48(1-2): 35-40.

Engel MS (1997) Ischnomelissa, a new genus of augochlorine bees (Halictidae) from Colombia. Studies on Neotropical Fauna and Environment 32(1): 41-46.

Engel MS (1998) Phylogeny, Classification, and Evolutionary Ethology of the Bee Tribe Augochlorini (Hymenoptera: Halictidae). Doctoral dissertation, Cornell University, Ithaca, $\mathrm{xxii}+306 \mathrm{pp}$.

Engel MS (2000) Classification of the bee tribe Augochlorini (Hymenoptera: Halictidae). Bulletin of the American Museum of Natural History 250: 1-89. 
Engel MS (2001) A monograph of the Baltic amber bees and evolution of the Apoidea (Hymenoptera). Bulletin of the American Museum of Natural History 259: 1-192.

Engel MS (2003a) A new species of the bee genus Chlerogella from Panama (Hymenoptera: Halictidae). Zootaxa 286: 1-4.

Engel MS (2003b) A new bee of the genus Chlerogella from Ecuador (Hymenoptera, Halictidae). In: Melo GAR, Alves dos Santos I (Eds) Apoidea: Neotropica: Homenagem aos 90 Anos de Jesus Santiago Moure. Editora UNESC [Universidade do Extremo Sul Catarinense], Criciúma, 135-137 [total volume pages xvi+320 pp.].

Engel MS (2007a) Two new augochlorine bees from Ecuador (Hymenoptera: Halictidae). Acta Entomologica Slovenica 15(1): 21-29.

Engel MS (2007b) A lateral gynandromorph in the bee genus Thyreus and the sting mechanism in the Melectini (Hymenoptera: Apidae). American Museum Novitates 3553: 1-11.

Engel MS (2009a) Revision of the bee genus Chlerogella (Hymenoptera, Halictidae), Part I: Central American species. ZooKeys 23: 47-75.

Engel MS (2009b) Notes on the augochlorine bee genus Chlerogas (Hymenoptera: Halictidae). Caldasia 31(2): 449-457.

Engel MS (2010) The bee genus Chlerogas in Bolivia (Hymenoptera, Halictidae). ZooKeys 46: $61-70$.

Engel MS, Brooks RW (1999) A new Chlerogelloides from French Guiana, with comments on the genus (Hymenoptera: Halictidae). Journal of the Kansas Entomological Society 72(2): 160-166. Engel MS, Brooks RW (2002) A new bee of the genus Ischnomelissa, with a key to the known species (Hymenoptera: Halictidae). Entomological News 113(1): 1-5.

Engel MS, Gonçalves RB (2010) A revised key to the species of Caenaugochlora (Ctenaugochlora), with the description of a new species from Costa Rica (Hymenoptera: Apoidea: Augochlorini). Genus 21(1): 101-110.

Engel MS, Gonzalez VH (2009) A new species of Chlerogas from the Andes of central Colombia (Hymenoptera: Halictidae). Caldasia 31(2): 441-447.

Engel MS, Brooks RW, Yanega D (1997) New genera and subgenera of augochlorine bees (Hymenoptera: Halictidae). Scientific Papers, Natural History Museum, University of Kansas 5: 1-21.

Engel MS, de Oliveira FF, Smith-Pardo AH (2006) A new species of the bee genus Chlerogas Vachal from Ecuador (Hymenoptera: Halictidae). Entomologist's Monthly Magazine 142(1703-1705): 103-106.

González VH, Ospina M, Bennett DJ (2005) Abejas altoandinas de Colombia: Guía de Campo. Instituto de Investigación de Recursos Biológicos Alexander von Humboldt, Bogotá, 80 pp.

Michener CD (1944) Comparative external morphology, phylogeny, and a classification of the bees (Hymenoptera). Bulletin of the American Museum of Natural History 82(6): 151-326.

Michener CD (1954) Bees of Panamá. Bulletin of the American Museum of Natural History 104(1): 1-176.

Michener CD (2000) The Bees of the World. Johns Hopkins University Press, Baltimore, xiv+[i]+913 pp. 
Michener CD (2007) The Bees of the World [2 $2^{\text {nd }}$ Edition]. Johns Hopkins University Press, Baltimore, $x v i+[i]+953 \mathrm{pp}$.

Moure JS (1944) Abejas del Perú. Boletin del Museo de Historia Natural "Javier Prado" 8: $67-75$.

Moure JS, Hurd PD, Jr (1987) An Annotated Catalog of the Halictid Bees of the Western Hemisphere (Hymenoptera: Halictidae). Smithsonian Institution Press, Washington, D.C., vii+405 pp.

Moure JS, Urban D, Melo GAR (2007) Catalogue of Bees (Hymenoptera, Apoidea) in the Neotropical Region. Sociedade Brasileira de Entomologia, Curitiba, xiv+1058 pp.

Smith-Pardo AH, Vélez-Ruiz RI (2008) Abejas de Antioquia: Guía de Campo. Universidad Nacional de Colombia, Medellín, 132 pp.

Vachal J (1901) Contributions hyménoptériques. V.- Hymenoptera mellifera americana nova. Annales de la Société Entomologique de France 70: 77-82.

Vachal J (1904) Étude sur les Halictus d'Amérique (Hym.). Miscellanea Entomologica 12: 9-24, 113-128, 137-144.

\section{Index}

Species covered herein are listed along with page for descriptive account and maps, and figure numbers (the latter in boldface).

agaylei $36, \mathbf{4 8 - 5 4 , 6 8 - 6 9}$

arhyncha 18, 18-23, 39-41

azurea 29, 33-38, 42-44

borysthenis 48, 74-76

breviceps 49, 77-79

buyssoni 18

cochabambensis $9, \mathbf{2 - 8 ,} \mathbf{1 4 - 1 5}$

cooperella 51, 80-83, 87-89

cyranoi $78, \mathbf{1 2 9 - 1 3 1 , ~ 1 3 9 - 1 4 0 ~}$

dolichorhina 34, 45-47

elysia 63, 99-106, 115-116

eumorpha 43, 62-67, 72-73

euprepia 60, 95-98

hauseri 14, 9-13, 16-17

hypermeces 66, 107-114, 117-118

materdonnae 39, 55-61, 70-71

mourella 58, 92-94 nasus 25, 27-29

octogesima 57

oresbios 84, 141-149, 154-155

picketti 76, 126-128, 137-138

rostrata $27, \mathbf{1}, 30-32$

silvula 54, 84-86, 90-91

terpsichore 72, 119-125, 135-136

tychoi 80, 132-134

vachali 22, 24-26

xuthopleura 89, 150-153, 156-157

Bolivia map 12

Colombia map 69

Ecuador map 33

Peru map 21

Venezuela map 87 